
BRAR F UNIVERSITY

CALIFORN 






\section{CALIFORNIA.}




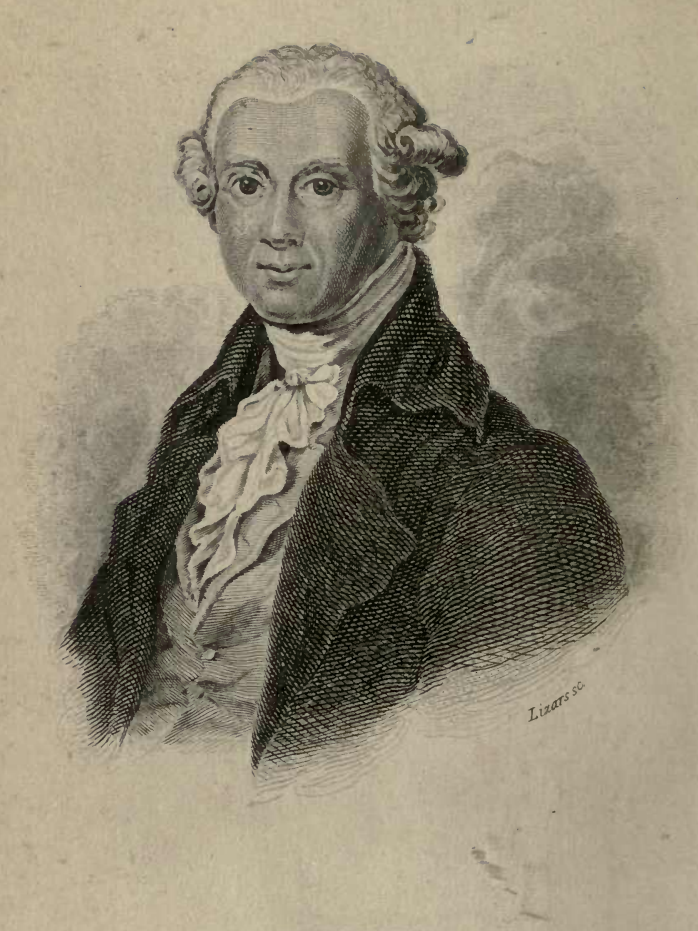

"YTS

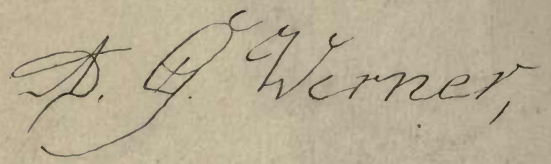

Limmanal for the. Matunilist's Libray. 
WATORAZIST'S LIBRABY.

进 \$Y



Larye Comer, \& Common Blue Butterflies.

LONDON, HENRY G. BOHN. YORK STREET, COVENT CARDEN. 

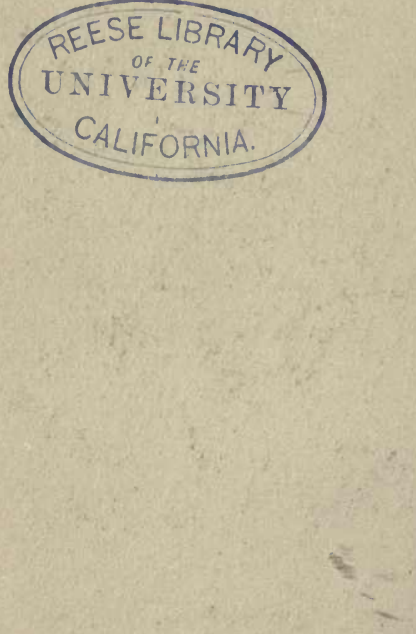
Plates $14,15 \$ 16$ are reversed. 11. $18 \frac{1}{5} 19$

-THE Qel plates untacx

\section{NATURALIST'S LIBRARY.}

EDITED BY

SIR WILLIAM JARDINE, BART.,

E.R.S.Z., F.L.S., ETC. BTC.

VOL. XXIX.

E N T O M L O G Y.

BRITISH BUTTERFLIES.

BY JAMES DUNCAN, M.W.s., ETC.

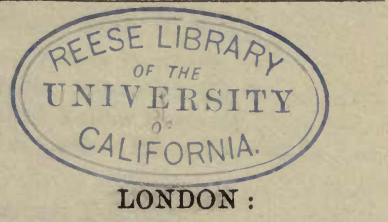

HENRY G. BOHN, YORK ST., COVENT GARDEN. 1860. 


$$
\begin{aligned}
& 0.14 k \\
& J 4 \\
& x, 29
\end{aligned}
$$



$\cos =$



mzs nov

$$
28681
$$




\section{CONTENTS.}

MeMoIr OF WerNer, PAgR

Account of the Wernerian Society of Edinburgh, 48

InTRODUCTION, . . . . . . . 49

Plate I. elementary and anatomical figures, \&c.

Plate II. ditto, ditto.

Plate III. Caterpillars, \&c.

Genus Papilio, $\quad$ c c . . . . . 92

Swallow-tail Butterfly.

Papilio Machaon. Plate IV. Fig. 1. . . 94

Scarce Swallow-tail Butterfly.

Papilio Podalirius. Plate IV. Fig. 2. $\quad$. $\quad 97$

Brimstone Butterfly.

Gonepteryx Rhamni. Plate V. Fig. 1. . 100

Clouded Yellow Butterfly.

Colias Edusa. Plate V. Fig. 2. . . . 103

Pale Clouded Yellow Butterfly.

Colias Hyale. Plate VI. Fig. 1. . . . 106

Scarce Clouded Yellow Butterfly.

Colias Europome. Plate VI. Fig. 2. . 108

Genus Ponria, . . . . . . 110

Common Cabbage Butterfly.

Pontia Brassica. Plate VII. Figs. 1, and 2. 113 
Early White Cabbage Butterfly.

Pontia Chariclea. Plate VIII. Fig. 1.-Nale. 116 Small White Butterfly.

Pontia Rapa. Plate VII. Fig. 3.

Howard's White Butterfly.

Pontia Metra. Plate VIII. Fig. 2.

Green-veined White Butterfly.

Pontia Napi. Plate IX. Fig. 1.

121

Dusky-veined White Butterfiy.

Pontia Sabellica. Plate VIII. Fig. 3. - 123

Genus Marcipium, . • . . . . . 124

Bath White Butterfly.

Mancipium Duplidice. Plate IX. Fig. 2. . 125

Orange-tip Butterfly.

Pontia Cardamines. Plate X. Figs. 1. \& 2. 127 Wood White Butterfly.

Leucophasia Sinapis. Plate X. Fig. 3. 128

Black-veined White, or Hawthorn Butterfly.

Pieris Cratogi. Plate XI. Fig. 2. . . 131 Apollo Butterfly.

Parnassius Apollo. Plate XI. Fig. 1., . 134

Duke of Burgundy Fritillary.

Nemeobius Lucina. Plate XII. Fig. 1. - 137

Genus Mejita, . . . . . . . 139

Pearl-Bordered Likeness.

Melitea Athalia. Plate XII. Fig. 2., . . 140

Greasy Fritillary.

Melitaa Artemis. Plate XIII. Fig. 2., • 142

Glanville Fritillary.

Melitaa Cinxia. Plate XIV. Fig. 2. . . 144

Pearl-bordered Fritillary.

Melitaa Euphrosyne. Plate XV. Fig. 2. . 145

Small Pearl-bordered Fritillary.

.Melitea Silenc. Plate XIII. Fig. 3,, • . 148 
Genus Argynnis.

Queen of Spain Fritillary.

Argynnis Lathonia. Plate XVI. Fig. 2. . 152

High Brown Fritillary.

Argynnis Adippe. Plate XVI. Fig. 1. - 153

Dark Green Fritillary.

Argynnis Aglaia. Plate XV. Fig. 1. . . 155

Silvel-Washed Fritillary.

Argynnis Paphia. Plate XIV. Fig. 1. $\quad 157$

Genus Vanessa, • • . . . . . 159

Comma Butterfly.

Vanessa C.-album. Plate XVI. Fig. 1. . . 160 Great Tortoise-Shell.

Vanessa polychloros. Plate XVII. Fig, 2. . 162 Small Tortoise-Shell.

Vanessa Urtica. Plate XIX. Fig. 1. . 164 Peacock's Eye.

Vanessa Io. Plate XVIII. Fig. 1. . . 166 Camberwell Beauty.

Vanessa Antiopa. Plate XVIII. Fig. 2. . 168 Red Admiral.

Vanessa Atulanta. Plate XX. Fig. 1. $\quad$. 170 Painted Lady.

Cynthia Cardui. Plate XIX. Fig. 2. . . 174

Purple Emperor.

Apaturo Iris. Plate XXI. • . . . 177

White Admiral.

Limenitis Camilla. Plate XX. Fig. 2. . 181

Genus Hipparchia. • • • . . • 184

Speckled Wood Butterfly.

Hipparchia Ageria. Plate XXIII. Fig. 4. 186

Wall Butterfly.

Hipparchia Megara. Plate XXII. Fig, 3. $\quad 188$ The Grayling.

Hipparchia Semele. Plate XXII. Figs. 1. \& 2. 190 
CONTENTS.

Marbled White Butterfly.

PAGE

Hipparchia Galathea. Plate XXIII. Fig.l.

Large Heath.

Hipparchia Tithonus. Plate XXIII. Figs. 2. and 3.

Meadow-Brown Butterfly.

Hipparchia Janira. Plate XXIV. Figs. 1. \& 2,, 196 The Ringlet Butterfly.

Hyparchia Hyperanthus. Plate XXIV. Fig. 4. 198 Mountain Ringlet.

Hipparchia Cassiope. Plate XXIV. Fig. 3.

Arran Brown Butterfly.

Hipparchia Ligea. Plate XXV. Fig. 1. - 201 Scotch Argus Butterfly.

Hipparchia Blandina. Plate XXV. Fig. 2. 202 Scarce Small Ringlet Butterfly.

Hipparchia Davus. Plate XXVI. Fig. 1. . 204 Marsh Ringlet Butterfly.

Hipparchia Polydama. Plate XXVI. Fig. 2. 205 Small Heath Butterfly.

Hipparchia Pamphilus. Plate XXVI. Fig. 3., 207

Silver Ringlet Butterfly.

Hipparchia Hero, . . . • . . 208

Hipparchia Arcanius, - . . . . 209

Brown Hair-Streak.

Thecla Betula. Plate XXVII. Figs. 1. \& 2. 211 Purple Hair-Streak.

Thecla Quercus. Plate XXVII. Figs. 3. \& 4., 212 Black Hair Streak.

Thecla Pruni. Plate XXVIII. Fig. 1. . 214 White Letter Hair Streak.

Phecla $W$-album. Plate XXVIII. Fig. 2. Green Hair Streak.

Thecla Rubi. Plate XXVIII. Fig. 3. • 217 Genus Lrcana.

Large Copper.

Lycana dispar. Plate XXIX. Figs. 1. \& 2., 


\section{CONTENTS.}

Scarce Copper.

Lyccena Virgaurea. Plate XXIX. Fig. 3. 222

Purple-edged Copper.

Lycana Chryseis. Plate XXX. Fig. 1 - 224

Dark Under-winged Copper.

Lycana Hippothoë. Plate XXX. Fig. 2。 - 225

Common Copper.

Lycana Phleas. Plate XXX. Fig. 3. - 226 Genus Polyommatus. • • • • • 228

Azure Blue Butterfly.

Polyommatus Argiolus. Plate XXXI. Figs. 1. and 2.

Bedford Blue Butterfly.

Polyommatus Alsus. Plate XXXI. Fig. 3. 230

Mazarine Blue Butterfly.

Polyommatus Acis. Plate XXXI. 2ig. 4. 231

Large Blue Butterfly.

Polyommatus Arion. Plate XXXII. Fig. 1. 233

Alcon Blue Butterfly.

Polyommatus Alcon. Plate XXXII. Fig. 2. 234

Chalk-Hill Blue Butterfly.

Polyommatus Corydon. Plate XXXII. Fig. 3. 235

Clifden Blue Butterfly.

Polyommatus Adonis. Pl. XXXIII. Figs. 1. \& 2. 237

Common Blue Butterfly.

Polyommatus Alexis. Vignette Title-page, $\quad 239$

Silver Studded Blue Butterfly.

Polyommatus Argus. Plate XXXIII. Fig. 3. 241

Brown Argus Butterfly.

Polyommatus Agestis. Plate XXXIV. Fig. 1. 243

Durham Argus.

Polyommatus Salmacis. Plate XXXIV. Figs. 2. and 3. $. . . \quad . \quad . \quad 244$

Artaxerxes Butterfly.

Polyommatus Artaxerxes. P1. XXXIV. Fig. 4. 245

Portrait of Werner, • • • .

Vignette Title-page. Tre Common Blue Butterfly, 3

In all Thirty-six Plates in this Volume. 



\section{MEMOHR OFERERNER*. \\ OF THE \\ UNI LIPSITY}

THE close of the seventeenth century witnessed the birth of a new science, which assumed, in its infancy, the pompous name of the Theory of the Earth. Starting with a few ill-ascertained facts, and connecting these together by fantastical assumptions, it pretended to go back to the origin of worlds, to sport, as it were, with them, and to create their history. Its arbitrary methods, and pompous language, seemed to remove it to a distance from the other sciences; and in fact, scientific men for a long period excluded it from the circle of their studies.

At length, after an age of fruitless attempts, it has been brought within the range assigned to the hu-

* Instead of writing anew the life of this distinguished individual, for which few materials could be procured that have not been already laid before the public, it has beer. thought that we should best consult the interest of our readers, and at the same time give an agreeable variety to nur biographical notices, by introducing, in an English form, the Eloge of Baron Cuvier, pronounced before the Royal Institute of France. This sketch furnishes all that is interesting in a life remarkably free from incident, and presents a view of Werner's opinions and discoveries, distinguished by the analytical talent and philosophical discern. ment for which its author was so eminent. 
man faculties, and, confining itself to the modest task of observing the globe as it actually exists, has penetrated into its bowels, and, in some degree, explained its anatomy. It has henceforth taken its place among the subjects of positive knowledge, and, what is very remarkable, it has done so without losing any thing of its marvellous character. The objects which it has been enabled to see and to touch, - the tuuths which it has daily brought under our eyes,are even more admirable and surprising than all that the most prolific imagination had ventured to conceive.

This happy reformation was commenced by two celebrated men, Pallas and Saussure; and it was completed by Werner. With him commences the most remarkable epoch of the science of the earth, - an epoch indeed which he himself may be said to have filled; for he had the good fortune to witness, during his own lifetime, the universal prevalence of his ideas and views, although they were so novel in their character, and foreign to the previous notions of most naturalists. He has left as many inheritors of his methods and doctrine as there are observers in the world; and wherever mines are wrought, or the history of minerals taught, some distinguished man is to be found, who accounts it an honour to have been his pupil. Entire academies * have been formed and distinguished by his name, as if they had

- See Account of Wernerian Natural History Society at tne end of this memoir. 
wished to invoke his genius, and make him their patron in a manner previously unknown.

When hearing of such unusual success, who would not suppose that he was one of those men who are most ardent in propagating their doctrines, and who have acquired an ascendency over their cotempora. ries by numerous and eloquent writings, or who have procured adherents through the influence of wealth, or an elevated station in society? But in his case there was nothing of all this. Confined to a small town in Saxony, without authority in the country, he could have no influence on the fortunes of his pupils. He formed no connexion with people in power; and such was the singular timidity of his disposition, and aversion to writing, that not more than a few sheets of his composition have been committed to the press. Far from seeking to render himself important, he was so little conscious of his own merit, that the most trifling honours conferred on him, even at a time when his reputation was spread throughout all quarters of the world, greatly surpassed all that he had ever hoped for or desired.

But this man, though so little occupied with himself, and so far from conceiving that he was in any degree called upon to write for the instruction of others, had an indefinable charm in his language and conversation. When once he had been heardwhen once, over a few fragments of stones or rocks disposed almost by chance, he had developed, as if by inspiration, all those general ideas and innumerable relations which his genius had perceived, no one 
could resist the force of his attractions. Feeling the ascendency of his talents, the pupils of Werner respected him as a great master, and, returning the regard he shewed for them, they soon loved him as a father. Wherever they went, they promulgated his doctrines, and spoke of his person with respect and affection.

It was thus that, in a few years, the little school of Freyberg, originally designed only for the instruction of a few miners for Saxony, again presented the appearance of the earliest universities of the middle ages. Pupils flocked to it from every civilized country; and, even in the most remote places, aged individuals, and men of science who had already attained the highest celebrity, hastened to acquire a knowledge of the German language, for the sole purpose of being in a condition to hear and understand the great oracle of Geology.

Abraham-Gottlob* Werner was boin on the 25th of September 1750, at Wehrau on the Queiss, in Upper Lusatia. From his earliest years, he was surrounded with the objects which were to form the occupation and the glory of his life. His father, who was the director of a forge, used to give him shining minerals for his playthings; and, before he could pronounce their names, the child was learning, by piling them together, tossing them about, and breaking shem in pieces, to group them, and recognise them by their most prominent characters. He always - Gottlob, Praise God 
preserved a few of these pieces, and, when he shewed his collection, which soon became one of the richest in Europe, he seldom failed to draw attention to these small beginnings of it, as if he wished to shew a kind of gratitude for the first sparks which proved the source of such abundant light.

It was intended that he should engage in the business of mining, and as the laws of Saxony require that those who embrace this profession should be regularly licensed, he first attended the courses of metallurgy in the school of Freyberg, and subsequently those of jurisprudence in the University of Leipsic.

Two prevailing tastes, or, it may be rather said, two passions, attended him through life - the love of minerals, and the love of method. He delighted in dividing and classifying things, like ideas. Whatever admitted of being arranged, gave him pleasure : and when he began to purchase books, he seemed to do so rather for the purpose of arranging them methodically, than in order to read them. Both these propensities were conspicuous in his first work, the Treatise on the External Characters of Minerals, a pamphlet of a few sheets, which he published at Leipsic when he was twenty-four years of age. It comprises an analysis and minute subdivision of all the variations in the apparent properties of minerals. Each of these properties is designated by an appropriate term, designed conjointly to form a definite language, by means of which all mineralogists may be readily understood.

This was rendering to mineralogy a service simi- 
lar to that which Linnæeus had conferred on botany; but it was a service purchased at the same price. It cannot be denied, that this vocabulary has introduced into seience more detail and precision; that persons who accustom themselves to apply it, acquire a remarkable facility in distinguishing minerals at the first glance; and that the attentive examination necessary to draw up a description of these substances on the prescribed model, has been the means of discriminating many which might otherwise have continued to be long confounded in the crowd. But it must be confessed, at the same time, that this idiom, necessarily somewhat pedantic, and restricted in its modes of expression as well as in its words, has given an affected air to the works in which it has been too servilely employed, together with a dryness and prolixity more frequently fatiguing than useful.

These inconveniences seem, however, to have been but little felt. Technical and half-barbarous terminologies had long been the reigning fashion. For thirty years the amiable science of botany spoke no other language, and naturalists, already accustomed to so many chains, experienced no apprehension at the prospect of submitting to another. Indeed, we may suppose, that if any one was alarmed at this new creation, it was Werner himself, and that if he wrote so little after his first trial, it was partly that he might escape from the trammels that he had imposed on others. Happily his early work, adapted as it was to the taste of the nation, made 
his name known, and procured him the means of transmitting his ideas in a more agreeable form.

He was nominated in 1775 Professor and Inspector of the Cabinets of Freyberg; - an appointment bestowed on him that he might devote himself without restraint to his strongest inclination, and which retained him in a district the most calculated of any in Europe to satisfy it, since it is the most abundant in different kinds of minerals, and has, from a remote period, been pierced in all directions by the operations of miners. All his efforts, therefore, from this moment, were directed to mineralogy, and to it alone ; but this single science, fecundated by his genius, became one of immense extent.

His first step had been to create for it a language: his second was to form a system ; but the latter, as it was much the most important, was also greatly the most difficult.

Organized beings present two bases of classification, obviously given by nature; the individual, resulting from the concourse of all the organs to 3 common action, and the species, resulting from the connexions which generation has established between individuals.

More remote resemblances, however natural the relations on which they are founded may be, are always more or less dependent on abstractions of the mind.

In mineralogy, classificators have sought in vain for some principle corresponding in every respect to 
these primary bases. The mysterious force of crystallization is the only one that presents any resem blance to the generative power: it determines in like manner the composition; but this is only within certain limits. Recent experiments have evinced that there are substances whose crystalline virtue is such, that they constrain very considerable quantities of different substances to accommodate themselves to their form ; and it has been long observed in nature, that crystals, in all respects alike, those of sparry iron, for example, may contain more or less of iron or of lime, as there may be in two animals of the same speeies a greater or less quantity of fat, of gelatine, or of the earth of the bones.

In mineralogy, therefore, crystallization must be regarded as the fundamental principle of the species, as far as it addresses itself to our sight; but in an immense majority of minerals, the crystalline form is not visible, and, in such cases, the composition is very far from enabling us to determine it; for the latter is more variable than in the crystals, and im. pure intermixtures corrupt it more easily. No alternative, then, is left, but to have recourse to the properties which are most closely connected with the fundamental principle, viz. cleavage, which is only one of its phenomena, fracture, hardness, lustre, and the effect of the body on the touch, which are its more or less immediate consequences.

This plan Werner has pursued, not perhaps proceeding exactly upon these reasonings, but led by that 
kind of delicate instinct which formed the peculiar character of his genius. He has the appearance of adopting the identical composition of the molecales as the principle of species, and as the point from which he sets out. Perhaps he really believed himself to have set out from thence; but he never actually applies the principle but when it is in perfect unison with the external properties, and, in all instances, it is on these properties that he has founded his distributions, leaving analysis to make itself harmonize with them as it best may. All unctuous stones, for example, are arranged in the magnesian genus, although many of them contain a greater proportion of argillaceous or siliceous matter than of magnesia. So rigorously did he act on this principle, that he always persisted in placing the diamond among the siliceous stones, although it had been incontestably proved by experiment that this gem is a crystallization of carbon. Still more singular is the fact, that, among all the external properties, he paid least regard to the crystalline form, which is the most fundamental of the whole.

It is true, that his investigations began ten years. before Haüy had commenced his labours, and, consequently, nearly thirty years before the doctrine of that great mineralogist had been developed in the admirable manner it afterwards attained; and Werner, on his part, had caused the science to make such remarkable progress, that he may easily be excused for not entering fully into all the views of his 
rivals. But the conduct of some of his followers arlmits of no excuse, who attempted, with an ill-directed zeal, which he took every opportunity of reprobating, to depreciate a series of truths with which he had made them too little acquainted. A contrary proceeding would have been greatly more proper, for it is necessary to unite and combine the results of the two methods. Far from being opposed to each other, they are absolutely the same in spirit, being in reality but two branches from the same stem. Both of them, without denying that species depend, in some respects, on composition, are too ready to establish them without sufficiently consulting chemistry. They assume for them, tacitly at least, a principle of individuality which is not inherent in the matter that composes them. But although chemistry reproaches both with sometimes establishing species gratuitously, she is obliged at the same time to acknowledge, that they have often anticipated her, by indicating distinctions in substances which she was unable to detect by her analysis, till after the fact had been announced.

The only difference is, that each of these two great mineralogists gives too exclusive a preponderance to the characters which have been most the object of his study.

Haüy, conceiving crystallization as a'one worthy of being compared with analysis, has recourse to more rigorous and scientific methods, but which permit many substances to escape notice. 
Werner, by admitting to the same privilege properties of a subordinate kind, embraces more easily all sorts of minerals; but, in so doing, he overlooks what is most profound and mysterious in their nature; and when, in the conflict of the two methods, he has opposed these subordinate qualities, not only to analysis, but to crystallization itself, he has almost always infringed that fundamental law, of which the properties he believed himself entitled to employ are only the corollaries.

Werner had thus invented a language for describing minerals, as well as a method of arranging them, and had assigned to each their distinctive characters; in this manner constituting a mineralogy, properly so called, or what he termed Oryctognosy, that is, a knowledge of fossils.

The history of their arrangement on the globe, or what he named Geognosy-knowledge of the Earth -was the third point of view under which he regarded then.

The Earth is composed of mineral masses; and modern observers have ascertained that these masses are not distributed at random. Pallas, in his laborious journeys to the extremities of Asia, had remarked that their superposition was capable of being referred to fundamental laws; and the same thing was confirmed by the observations of De Saussure and De Luc, while traversing, in numerous directions, the most elevated mountain-ranges in Europe. Without quitting his small province, Werner ac- 
quired the most intimate acquaintance with these laws, and could read in them the history of all the revolutions from which they had resulted. Following each bed in the order of its continuity, without allowing himself to be bewildered by rents and shift. ings, or by the crests and other summits which rise above them, he in some measure determined their age, and the age of all the accessory matters which intermingle with their principal substances.

The different fluids which have surrounded the globe, the changes in composition which they have undergone, and the violent commotions by which each change has been accompanied, were all legible to his eyes on the monuments which they have left behind them.

A universal and tranquil ocean deposites in large masses the primitive rocks, which are strongly crystallized, and have silica for their predominating ingredient. Granite forms the base of the whole. To this succeeds gneiss, which is nothing more than granite beginning to assume a slaty structure. By degrees, argil begins to predominate. Schists of different kinds appear; but in proportion as the purity of the precipitations becomes changed, the distinctness of the crystalline grain diminishes. Serpentines, porphyries, and traps succeed, in which the grain is less distinctly formed, although a siliceous nature begins to resume its purity. Internal agitation in the fluid destroys a portion of these primary deposites; and their debris forms new rocks. 
united by a cement. It is in the midst of these commotions that life first begins to appear. Carbon, the first of these products, now shews itself. Lime, which was associated with the primitive rocks, becomes more and more abundant; and rich deposites of sea-salt, one day to be explored by man, fill large cavities. The waters, again becoming tranquil, but having their contents changed, deposit beds less thick, and more varied, in which the remains of living bodies are successively accumulated, in an order not less determinate than that of the rocks which contain them. At last, the final recession of the waters spreads over the continent immense alluvial collections of moveable substances, which form the earliest seats of vegetation, of culture, and of social life.

Metals, like rocks, have had their epochs and their successions. The last of the primitive, and the first of the secondary rocks, have received them abundantly. They become rare, however, in deposites of more recent formation. They are usually distributed in particular situations, in those veins which seem to be produced by rents in the rocky masses, and filled after their formation; but they are by no means of equal age. The last formed are known by their veins intersecting those of older date, and not being themselves intersected. Tin is the oldest of the whole; silver and copper the most modern. Gold and iron-those two masters of the world-seem to have been deposited in the bowels of the earth at all the periods of its formation; but at each pe- 
riod iron appears under different forms, and we can assign the age of its different mines.

The necessity of abrilgment obliges me thus to bring together, under one view, results which, as may easily be conceived, could not be obtained but by many thousand observations. All Werner's observations, however, were made with so much care, and so scrupulously combined, that their accuracy has been confirmed by all subsequent investigation; and if we except his opinions regarding volcanic countries, none of his views met with any opposition which did not soon pass away.

Such, then, is the nature of Geognosy, or of the position of minerals, viewed as lying above one another, or in a vertical direction. But in their horizontal position-that is, as they are placed by the sides of each other-there are likewise differences, of which it is important to take notice. These differences form the fourth point of view under which Werner regards minerals, and which he designates by the name of Geographical Mineralogy.

Indeed, the rocks of most recent formation, and which lie above the others, are the least elevated; the oldest penetrate through them, and form high mountains. From this we infer, that the fluid sunk in its level, in proportion as the solid substances increased. It divided itself into basins, the productions of which became of a diversified character. The surface of different countries is therefore dissi- 
milar - a fact which becomes more manifest, the more attentively we examine their structure.

But every mineral is cupable of being turned to some useful purpose ; and, on the greater or less abundance of particular kinds in certain localities, and the ease or difficulty with which they are obtained, often depend the prosperity of a people, their advancement in civilisation, and all the details of their manners.

In Lombardy, for example, we see only houses of brick; while Liguria, which is contiguous to it, is covered with palaces of marble. Its quarries of travertin made Rome the most beautiful city of the ancient world; those of coarse limestone and gypsum have rendered Paris one of the most agreeable of modern times. But Michael Angelo and Bramanti could not have built at Paris in the same style as at Rome, because the same materials were a. wanting; and this influence of local soil extends to things very remote and important.

Under the shelter of those ridges of limestone which intersect Italy and Greece, varying in height, branching in numerous directions, and giving rise to abundance of rivulets; - in those charming valleys, rich in all the products of animated nature, philosophy and the arts first sprung up. It was these that gave birth to minds of which the human race have most reason to be proud; while, on the other hand, the vast sandy plains of Tartary and Africa have al. ways prevented their inbabitants from becoming any 
thing else than fierce and wandering shepherds. In countries where the laws and even the language are alike, an experienced traveller can conjecture, from the habits of the people, and the appearance of their dwellings and clothing, what is the composition of the soil, in the same manner as a philosophical mineralogist can infer, from the same source, what are likely to be their manners, as well as their degrees of comfort and instruction. Our granitic districts produce very different effects on all the habits of the people from those that are calcareous. The natives of Limousin, or of Lower Bretagne, are neither lodged nor fed like those of Champagne or of Normandy ; and it may even be said that they do not think alike. Even the results of the conscription have been different, and the difference is conformable to a uniform law in the different districts.

Geographical mineralogy, then, assumes a high importance, when we connect it in this manner with what Werner called Economical Mineralogy, or the history of minerals as applied to the wants of man.

The comprehensive mind of this great Professor seized with equal facility all these relations, and his auditors listened, with an ever new delight, to the exposition of such of them as the plan of his public prelections permitted him to embrace. But, in lis private conversations, he followed up their application to a much greater length. The history of man and languages was connected, according to his views, with that of minerals; and he never conceived that 
he was departing from his principal subject, by indulging in these other inquiries. He traced the migrations of different tribes by the inclinations and directions of countries, and in this way connected their marches and stations with the structure of the globe. He grouped the various languages together, and, tracing each to a common source, originating always in the highest central land of an elevated mountain-range, he regarded each dialect, as descending and subdividing, according to the direction of the valleys, becoming soft or harsh as it happened to become stationary in a level or a mountainous country, and, in process of time, departing in its character for the allied tongues, the more widely as the natural obstacles to communcation became more insurmountable.

Even the laws of the military art Werner endearoured to trace to those of geology ; and if his account was to be received, every general should have commenced his career by studying for some time at Freyberg. In a word, he referred every thing to the object of his own passion, and, as Tournefort, the celebrated botanist, formerly imagined that even stones vegetated, Werner in like manner fancied that stones could speak, and he thought bimself warranted confidently to demand of them the whole history of the world.

Strangers who happened to visit Freyberg, and expected to enter into conversation with a minera'ogist only, were surprised at his continual discus 
sions on tactics, politics, and medicine. They were sometimes tempted to regard them as allied to the reveries of a maniac. Indeed, we may admit that there must have been something of exaggeration in generalizing to such an extent the relations of a single object; but it ought also to be kept in mind to what a degree those conceptions, of so varied and exciting a nature, presented in an attractive and often eloquent form, must have warmed the imaginations of youth. At that age, when exceptions are so much disliked, and difficulties so easily surmounted, the disciples of Werner hurried with enthusiasm upon a field of inquiry which he described to them as so vast and fruitful. A mineralogy purely mincralogical would perhaps have disgusted many of them; but they devoted themselves with ardour to a mineralogy which seemed to present them with the key of nature; and even although, on a final analysis, there might only remain to them the foundation of the science, would they not still have reason to rejoice at the pleasing illusions which had been the means of leading them thither?

Some individuals who have since risen to the first rank among the mineralogists of Germany, had wished to hear him, only for the purpose of obtaining a summary knowledge of mineralogy; but having once listened to him, that science became the profession of their lives.

It is to this irresistible influence that the scientific world has been indebted for those laborious aut 
thors, who have so carefully described the different states in which minerals exist; and for those indefatigable observers who have removed from the globe the last veil that concealed her mysteries. Karsten and Wiedeman in the cabinet-Humboldt, Von Buch, Daubuisson, Hermann, and Freyensleben, on the summit of the Cordilleras, amidst the flames of Vesuvius and Ætna, in the deserts of Siberia, in the deepest recesses of the mines of Saxony, of Hungary, of Mexico, and of Potosi-have been led ou by the spirit of their master. They always ascribed to him the honour that resulted from their labours; and it might be said of him, what could formerly be said with truth of Linnæus only, that Nature was every where interrogated in his name.

Few masters have enjoyed in the same degree the pure and unreserved gratitude of their scholars; but no one, perhaps, had ever so much deserved it by his paternal regard for them. There was no sacrifice which he would not make for his pupils. His time and strength were at their service; and if he knew of any of them in temporary need, his purse was opened to supply their wants. When his audience became too numerous for each to see conveniently the objects which he exhibited, he divided the students. and repeated the lecture. His door was at all times open to them: he took his meals usually with some of them in company, as if he had wished that no opportunity should be lost for their instruction.

Such a master might well entrust the care of his 
reputation to his scholars; and it is in fact by them that it has been established. In this point, also, resembling Socrates, to whom he has been compared in so many other respects, nothing can be known of his views but from the notes that have been taken of his lectures. Whether it was that he was satisfied with the indisputable ascendency which he acquired by his powers of speaking, or that the vivacity of his imagination could not submit to the restraint and tediousness of writing, it was not without the greatest difficulty that he prevailed on himself to prepare for the press one or two pamphlets, and a few articles for the journals. But he engaged in oral dis. cussion as readily as could be wished, and his conversation was that of a man of genius, as well as of benevolent feeling. For hours together he would continue to utter the boldest and best connected ideas; but nothing could make him take up a pen. $\mathrm{He}$ had an antipathy even for the mechanical act of writing, which was rendered amusing by its very excess. His letters are extremely few. The tenderest friendship, the most profound esteem, could scarcely extort one from him; and at last, that he might not reproach himself for this want of politeness, he ceased to open such letters as were sent to him. One author, who was desirous to have the opinion of many scientific men respecting a voluminous work, circulated his manuscript among them. During its progress the packet was lost. After a thousand researches, it was at last disinterred from 
under a hundred others in the house of Werner To carry this matter to the extremity, he did not even reply to this Academy when it placed him on the list of its eight foreign associates, which is adorned with all the great names of which Europe can boast for more than a century; and perhaps he did not even know that this honour had been conferred on him, unless he happened to learn it from some almanack.

But we may well pardon him, when we learn, that, about this same period, an express sent to him by his sister from Dresden, was obliged to wait two months at an inn, and at his expense, before a simple signature could be obtained to a paper relating to some urgent family business.

This insurmountable antipathy to writing seemed the more unaccountable, as it caused him to infringe the laws of etiquette, which, next to bis studies, was the subject that affected him most. In every thing else, he is said to have observed the slightest courtesies of social life with as much punctuality as he attended to the varieties of minerals. This spirit of formality, which was preserved in Germany for a longer time than any where else, and in Saxony longer than in any other part of Germany, was particularly remarkable in him, apparently because it seemed in his eyes a kind of method. He deliberated about the arrangement of a dinner with as much gravity as about the arrangement of his library or cabinet. 
There was still one other point, however, to which his observance of etiquette did not extend. Whatever might be the rank of any individual, if he handled his minerals awkwardly, he was put out of all temper. The least stain on their freshness or lustre, wounded him to the quick, and he long preserved a deep recollection of it. Of such individuals, he was accustomed to say, with his usual good humour, that such a one was a great minister or a skilful general, but, he added with a sigh, he knows not how to handle minerals.

These little eccentricities, at which he was the first to smile, were no way unpleasant when allied to whatever is most elevated in genius, and amiable in disposition. They had no influence on that affectionate veneration entertained for him by his youthful pupils, who were ever happy to be instructed, and warmed by his words and attentions. They studied his peculiarities only to accommodate themselves to them-eager to shew their attachment even by attending to his foibles.

But these peculiarities the public and posterity will have reason to lament, as they have been thereby deprived of valuable works, which no other person, for a long time, will be able to execute so well. It is said that the first sheet of his great work on mineralogy was sent to the press, but that he could not undergo the fatigue of correcting the proofs.

His whole life was thus spent either in the regions of lofty contemplation, or in the pleasures of philo- 
sophical and friendly conversation - ignorant of all that was going on at a distance, without reading the journals of literature, and without even ascertaining whether envy had occasionally made him the object of her attack. His life might have been expected to be prolonged for a considerable time; for, of all the methods which he had studied, that of taking care of his own health had not occupied him least. Among his whims, his anxiety never to be placed between two currents of air, was one of the most noticeable. But of all his precautions, the most effectual was the tranquillity of a peaceful mind, which sought to avoid every thing that might excite in it malevolent feelings.

The misfortunes of Saxony were the only calamities that escaped his foresight, and destroyed the peace which it had procured him. He tenderly loved that country with which he was identified in a thousand ways; no offer could ever prevail on him to leave it. He loved a prince who protected the sciences, because he had studied them profoundly, and whom forty years of wise administration, and of affectionate devotion to his people, could not preserve from so many calamities. His courage could not stand the sight of the sufferings of his master and of his country, and his anxiety and distress produced a complication of diseases, to which no care could administer a remedy. He died in the arms of bis sister, on the 30th of June 1817, at Dresden, 
whither be had gone in the hope of some alleviation of his sufferings.

It seems as if fortune had brought him to this capital, that he might there receive the most solemn honours. The most illustrious persons in the kingdom assisted at his obsequies. M. Bottiger, a distinguished philosopher, publicly pronounced his funeral oration. The most celebrated acadernies of Germany have already paid him the same tribute which we this day render to him, and which will be decreed to him, under one form or other, in every quarter of the world where any branch of the science of the Earth is cultivated.

ACCOUNT OF THE WERNERIAN NATURAL HISTORY SOCIE'Y OF EDINBURGH.

[From Blackwood's Magazine for June 1817.]

To determine the utility of Natural History, it is scarcely necessary to do more than to enumerate its various branches by which it will be seen in its most convincing form. In truth the correctness of this opinion requires no proof, since the general attention which has, within a few years, been excited to the study of every departinent of natural knowledge, must have rendered every illustration that can be offered perfectly familiar to cur readers. This be- 
ing the admitted fact, the importance of all attempts to facilitate such studies, to excite ardour, and to stimulate exertion, will be fully appreciated. Under the influence of this conviction, we make no apology for submitting to the public the following sketch of the rise, progress, and present state of the Wernerian Natural History Society of Edinburgh, as well as a few general observations on that branch of natural history, to which some of its most distinguished members have hitherto devoted their talents. To this society, we, without hesitation, refer not only a large share of the enthusiasm that has been kindled, but some of the most interesting observations on the internal structure of Great Britain that have yet been presented to the world. In addition to this view, it will be well to illustrate its truth, and to trace the insensible though progressive influence that has been exercised on the minds of many, by one enlightened, zealous, and persevering Individual.

On the Continent of Europe, the first steps towards improvement in mineralogical knowledge were made; while, in our own country, though so rich in its mineral treasures, scarcely a work appeared, with the exception of Williams' Mineral Kingdom, and Price's Cornwall, that contained acourate observations. Yet in the midst of this most deplorable ignorance of the works of nature, her most secret mysteries were resolved with a boldness and temerity searcely to be surpassed by the flights of Para- 
celsus, or of Arnoldus de Villa Nova. It would be a fruitiess and unprofitable task to give even a sketch of these whimsical, though often ingenious, fancies.

The individual to whom mineralogy is most deeply indebted, is the well-known WERnER of Fr yberg. He has taught the vast importance of accurate observation, and patient investigation. He has shown, that in this science, as in every other, facts should not be made to bend to hypothesis; but that every man who wishes to obtain accurate vi ws, should begin his career unfettered by theory - and that the result must be a more accurate and extensive acquaintance with the materials of this globe.

While this illustrious man was silently pursuing his useful career in Germany, other philosophers in this country, of high talent, boldly struck out general views, which, though not remarkable for accuracy, entitled their authors to the character of genius and of fancy. Dr Hutton of Edinburgh took a decided lead in this matter; and, had he studied nature, and then theorized, his genius would, in all probability, have illustrated many difficult points; but it is obvious, from his own works, that he has frequently reversed this order of proceeding.

While these dazzling speculations allured the votaries of Hutton, the present Professor of Natural History in the University of Edinburgh first became known to the world as a scientific man, by his Mineralogy of Arran and Shetland, published in 1798. 
and afterwards in 1801, by his Mineralogy of the Scottish Isles. In these works, he gave a flattering earnest of his accurate views in the study of science, and of his indefatigable zeal in the attainment of it.

About 1804, Mr Playfair's beautiful and eloquent Illustrations of the Huttonian 'Theory were first published. In this work, all that eloquence, fine taste, and infinite ingenuity, could do, were united to vindicate and establish the doctrines of which the author may be considered the most illustrious champion. Public attention having been strongly excited on these topics by the impugning of Dr Hutton's creed by Professor Jameson, the contest became keen; and the result has been, to establish, very universally, the important fact, that the science of mineralogy is only to be acquired by patient labour, and that theory is as useless as contemptible, unless supported by a " cloud of facts."

In this state of general scientific excitement, those who felt anxious to render it beneficial, naturally sought for channels through which its influence might be judiciously directed. The most obvious was the establishment of societies, which, while protecting and encouraging every branch of natural history, would afford due support to mineralogical science in all its parts, whether regarded as furnishing materials for the philosophic inquirer, or as directing the operations of the practical mineralogist. To rouse a certain interest in the neglected though bighly interesting walks of science, was an object of 
importance to every one who had perceived and felt the inconveniences resulting from the old system. Professor Jameson (who may be considered the founder of mineralogical science in Great Britain) had contemplated the object of this sketch soon after his return from Germany; and as the public attention had been strongly solicited, by his valuable works, to one department of natural history, it was considered a favourable opportunity to bring together, in an organized form, such individuals as were desirous of extending the bounds of our natural knowledge in general, without limiting the tendencies of its original founders. Accordingly, on the 12th January 1808, Professor Jameson, Doctors Wright, Macknight, Barclay, and Thomson, Colonel Fullerton, Messrs Anderson, Neill, and Walker (now Sir Patrick Walker) held their first meeting, and " resolved to associate themselves into a society for promoting the study of natural history; and in honour of the illustrious Werner of Freyberg, to assume the name of the Wernerian Natural History Society." Professor Jameson was elected the first president ; Doctors Wright, Macknight, Barclay, and Thomson, the vice-presidents; $\mathrm{Mr}$ Walker, the treasurer; and $\mathrm{Mr}$ (now Dr) Neill, the secretary. Honorary and other members were elected - and among the first of the former, the society has the honour of enumerating the illustrious names of Werner, Sir Joseph Banks, Kirwan, and many other celebrated individuals. At the same time, it was resolved that a charter should 
be applied for; and accordingly, this being done, the Lord Provost and Magistrates of Edinburgh, by virtue of authority vested in them, granted the charter on the 10th February 1808; thus solemnly incorporating the Society.

The objects of this Society are simply the general promotion of every branch of natural science. Some, who are more disposed to cavil than to reflect, have objected to the distinctive title assumed by the founders of the Wernerian Society, as narrowing its scope. Werner, it is true, is chiefly, if not exclusively, known in Britain as a distinguished mineralogist. His knowledge, however, extended to every branch of natural science, and is regarded, by those who have possessed the singular advantage of his instruction, as equally remarkable for its accuracy as for its extent.

The honourable compliment paid to Werner's merits, as a man of science, ought to be considered, what it really is, as analogous to similar distinctions bestowed on Linnæus in this country, and on other eminent men on the Continent. The name implies no determination blindly to support Werner's peculiar views - as may be shown from the published memoirs, which contain undeniable proofs of freedom of discussion.

The Society has now existed upwards of twentyseven years, during which period its records have been graced with the names of all the most distinguished philosophers of Europe and America; and 
although unaided by the advantages of wealth, it has has silently pursued its useful career, and has, both directly and indirectly, contributed most essentially to the well-doing of science. Most of the active members of this society are professional men, whose daily engagements circumscribe the sphere of their scientific utility; yet, notwithstanding this and other dis. advantages, they have explored a large portion of country - have contributed several valuable papers, which have been published, besides others of equal importance, which will, in due season, appear at the bar of the public. While the individual members are thus co-operating in their efforts, the society, as a body, has not been negligent of its more immediate duties. Six volumes of memoirs, containing several very valuable papers, have been already published; and the merits of these volumes are sufficiently known to the scientific world; and as analyses of these volumes have been formerly given elsewhere, it is unnecessary for us to enter into such details.

The course hitherto adopted by the Wernerian Society has been unquestionably good; and upon the whole, we are disposed to think that a quiet unobtrusive career, in which solid foundations, for future distinction and lasting reputation, are laid, is to be preferred to that rapid course which dazzles for a while, but leaves no fixed and permanent impression. When, indeed, we recall the circumstances under which it wa first established - when we re. 
collect the odium which was attached to the very name-we cheerfully offer the tribute so merited by him, to whose intelligence, liberality, and unwearied diligence, we owe all that true spirit of mineralogical inquiry now abroad, and which bids fair to place our country among the first where such studies have been successfully cultivated. While we thus bestow praise where it is due, we cannot refrain from ten. dering our mite to the Geological Society of London, which has done so much towards elucidating the internal structure of England. Sincerely must it be wished, by every true lover of science, that these two societies may cordially co-operate in their com mon objects. Let this be the case, and we shall anxiously apply to them the spirit of the dying address of Father Paul to his country - "Estote perpetua." 



\section{LEPIDOPTERA.}

\section{INTRODUCTION.}

Cnild of the sun! pursue thy rapturous flight, Mingling with her thou lov'st, in fields of light ; And where the flowers of paradise unfold, Quaff fragrant nectar from their cups of gold. There shall thy wings, rich as an evening sky, Expand and shut with silent ecstasy. Yet wert thou once a worm, a thing that crept On the bare earth, then wrought a tomb, and slept! And such is man; soon from his cell of clay To burst a seraph in the blaze of day !

ROGERS.

The primary division, or Order, of the Class of Insects, to the illustration of which the present volume is devoted, acquires is name, like all the other Linnean orders, from the characters presented by the wings. These members have their entire surface covered with a thick coating of minute imbricated scales, which has caused the insects to be designated by the name Lepidoptera, from $\lambda \varepsilon \pi i s, a$ scale, and $\pi \tau \varepsilon \rho$, , wings. . This clothing, however, is not universal in the group, as there are several genera partially denuded of scales, and others in which the wings are clear and transparent, without any traces of them But these occasional deviations from 
prevailing structure indicate no essential disagree. ment, nor do they disturb the regularity of the order, which is perhaps the most natural and best defined of the whis?.e.

The species which it includes are popularly known as Butterflies, Hawk-motis, and Moths; terms which nearly correspond to the genera Papilio, Sphinx, and Phalæna, as originally constituted by Linnæus, and to the sectional divisions of more recent writers, founded on the seasons of flight, Diurnal, Crepusoular, and Nocturnal. Many of these are among our most common insects; and the curious economy of some, and the remarkable beauty of others, have long attracted the notice of observers; while their varied forms, and gorgeous colouring, have afforded subjects of the highest interest to the lovers of the pictorial art. Their amount is so considerable, that the Lepidopterous order ranks among the most extensive with which we are acquainted. There is reason to believe, that it is surpassed only by the Coleoptera or Beetles; and some authors are even inclined to assign it a precedence in this respect over that numerous order. In this country alone, although its variable and humid climate seems but little adapted to the welfare of creatures formed above all others for sunshine and calm, they fall very little short of 2000. From this we may infer that their numbers are very great in countries every way adapted to their increase.

The diurnal Lepidontera, or such as fly during 
the day, to which the present notice must be restricted, are the kinds which are known in this conntry by the name of Butterfly. This term is a literal translation of the Saxon word Buttor-fleoze, and is supposed to be applied because the insects first become prevalent in the beginning of the season for butter. They are distinguished from the other scalywinged kinds, by possessing antennæ with a knob or club at the summit, * and holding their wings, when in a state of repose, erect or very slightly inclined. They are the most generally and familiarly known of our insect tribes, and, by their conspicuous appearance, seldom fail to attract the notice even of those whose perceptions are least alive to the beauty of natural objects. The graceful curves of their outline - their gay and fitful flight - the splendour of their colouring and decorations, which present every variety of tint found in the different kingdoms of nature, distributed in markings and delineations of the most beautiful and diversified character, seem to confer on them a kind of superiority over other insects. Some naturalists have accordingly considered them as entitled to stand at the head of the Insect Class; and if, as $\mathrm{Mr}$ Kirby remarks, beauty, and grace, and gaiety, and splendour of colours were the great requisite, and the law enjoined Detur pulchriori-

- Certain foreign genera, however, such as Morpho and Urania, form an exception to this rule, as they have antennæ either of equal thickness throughout, or tapering slightly to the summit. 
they are doubtless deserving of this preference. Their wings are augmented to a size that seems quite disproportioned to that of the body, as if nature had wished to enlarge the surface on which she was to employ her pencil, that it might admit of more varied and profuse decoration. Even the under face of the wings, contrary to what is observed in other flying animals, is usually as much adorned as the surface, and often in an entirely different manner. Each wing, therefore, presents what may be called two different pictures. No kind of ornament found among other insects is omitted in this favoured tribe; and so many new modes of embellishment are employed, that Nature seems to have made them the b jects of her peculiar care, and designed them, as has been remarked by the learned and pious Ray, for the adornment of the universe, and to form delightful objects for the contemplation of man, bearing conspicuous marks of the hand of a Divine Artist. *

The habits of these insects are well fitted to confirm the preference we assign to their beauty. Unlike many others of this class, which delight to riot among substances most offensive to our senses, or

- Usus Papilionum -ad ornatum universi, et ut hominibus spectaculo sint; ad rura illustranda velut tot bracteæ inservientes. Quis enim eximiam earum pulchritudinem et varietatem contemplans mira voluptate non afficiatur? Quis tot colorum et schematum elegantias naturæ sius $d$ ivinæ artis vestigia eis impressa non agnoscat et miretur?-RAII, Hist. Insect. 109. 
which destroy the property and lives of their less powerful companions, butterflies derive their sustenance from the nectareous juices and secretions of fruits and flowers. Instead of grovelling on the " dungy earth," they are generally seen either sporting in the air, or resting on the disk of some expanded flower, and all their habits are such as beseem " pure creatures of the element." They are seldom noticed but in fine weather, and never in profusion but when the season is in its highest bloom, and their appearance thus becomes associated in our minds with the charms of external nature, and is connected with those images of life and beauty which give rise to many of the genial influences of summer. Several species also contrive to outlive the winter, although their frail forms seem but ill adapted to resist the rigours of that inclement season, and issuing from their retreats in the first warm days of spring, are among the earliest and not least interesting heralds of the "purple year*". These circumstances, together with the very striking manner in which they exhibit the phenomena of transformation, have long rendered them general favourites, and caused their history to be investigated with greater attention than

- In the sunny clime of Italy, where it may be said that nature never dies, and probably also in other southern countries of Europe, most of the species which with us retire on the approach of winter into the crevices of walls, and other sheltered situations, are seen upon the wing throughout even the colder months - at least we know that it is so with Van. cardui, Atalanta, and a few others: 
has been bestowed on insects of a less conspicuous and attractive kind.

The diurnal Lepidoptera are very numerous in species, although but a limited number inhabit this country. Between 2000 and 3000 have been described, and it is probable that no inconsiderable number yet remain undiscovered. About 75 different species are recorded as indigenous to Britain. A great proportion of the largest and most highly ornamented kinds are natives of the new world, especially of Brazil ; but they abound in all tropical countries, and some of these exotics present the most sumptuous examples of insect beauty. "I should undertake an endless task," say Messrs Kirby and Spence, or one or other of these authors, " did I attempt to specify all the modes of marking, clouding, and spotting, that variegate a wing, and all the shades of colour that paint it, among the lepidopterous tribes; I shall therefore confine myself to a few of the principal, especially those that distinguish particular tribes and families. Of whole coloured wings, I know none that dazzle the eye of the beholder so much as the upper surface of those of Morpho Menelaus and Telemachus. Linné justly observes, that there is scarcely any thing in nature that, for brightness and splendour, can be paralleled with this colour: it is a kind of rich ultramarine, that vies with the deepest and purest azure of the sky; and, what must cause a striking contrast in flight, the prone surface of the wings is as 
dull and dark as the supine is brilliant, so that one can conceive this animal to appear like a planet in full radiance, and under eclipse, as its wings open and shut in the blaze of a tropical sun. Another butterfly (Papilio Ulysses), by its radiating cerulean disk, surrounded on every side by a margin intensely black, gives the idea of light first emerging from primeval obscurity: it was probably this idea of light shining in darkness, that induced Linné to give it the name of the wisest of the Greeks in a dark and barbarous age: I know no insect upon which the sight rests with such untired pleasure as upon the lovely butterfly that bears the name of the unhappy Trojan king ( $P$. Priamus); the contrast of the rich green and black of the velvet of its wings with each other, and with the orange of its abdomen, is beyond expression regal and magnificent." *

Although our British butterflies can in no way compete with the magnificent examples just referred to, we yet possess many of great beauty, whether as regards the brilliancy of their colour, or the harmonious manner in which these colours are distributed. The bluish-purple reflection that plays on the wings of the Emperor of the Woods, has a richness and brilliancy of tint, which is not often surpassed. The prevailing hue among the Lyccence, is fulgid copper colour, of a high degree of resplendency; and the Polyommati, which are so abundant in our pastures, are remarkable for exhibiting, in great variety of shade, the most delicate and beautiful tints

- Introduction to Entomology, iii. p. 651. 
of blue. What can exceed the fine pencilling and harmonious tinting on the under surface of the wings of Cynthia Cardui, Limenitis Camilla, and Vanessa Atalanta; or the richness of the eye-like spots that decorate the wings of the Peacock Butterfly, and numerous other species? The warm and beautiful shades of yellow in Colias and Gonepteryx, render them objects on which the eye rests with continual pleasure; and the silvery spots and streaks on the under side of the Fritillaries, form a fine relief, by their brilliant metallic lustre, to the uniform and comparatively duller tints of black and brown which predominate among that tribe.

The mode of painting employed to produce these rich tints, may not improperly be called a kind of natural mosaic, for the colours invariably reside in the scales, which form a dense covering over the whole surface. These scales are usually of an oval or elongated form, and truncated at the tip, where they are occasionally divided into teeth; but sometimes they are conical, linear, or triangular. (A considerable number of the most remarkable forms which they exhibit, are represented at the top of Plate I. fig. 1. Fig. 2, shews the form they sometimes assume in the fringe which surrounds the wing.) They are fixed in the wing by means of a narrow pedicle, and are most commonly disposed in trans. verse rows, placed close together, and overlapping each other like the tiles of a roof. In some instances, they are placed without any regular order, and in certain cases there appear to be two lyers of 


\section{REESE LIBPA UNIVERSITY}

\section{CALIFORNIA.}


scales on both sides of the wings. When they are rubbed off, the wing is found to consist of an elastic membrane, thin and transparent, and marked with slightly indented lines, forming a kind of groove for the insertion of the scales. The latter are so minute that they appear to the naked eye like powder or dust, and as they are very closely placed, their numbers on a single insect are astonishingly great. Leeuwenhoek counted upwards of 400,000 on the wings of the silk moth, an insect not above onefourth of the size of some of our native butterflies. But how much inferior must this number be to that necessary to form a covering to some foreign butterflies, the wings of which expand upwards of half a foot; or certain species of Moths, some of which (such as the Atlas Moth of the east, or the Great Owl Moth of Brazil), sometimes measure nearly a foot across the wings! A modern mosaic picture may contain 870 tesserulæ, or separate pieces, in one square inch of surface; but the same extent of a butterfly's wing sometimes consists of no fewer than 100,736 !

In common with several other extensive races of insects, butterflies derive their nourishment entirely from liquid substances, and the structure of the mouth is consequently very different from that of the masticating kinds. They are hence classed among the haustellated or suctorial tribes of insects. The most conspicuous and elaborately constructed organ, is the long flexible tube projecting from the mouth, 
which forms a canal through which the ailmentary juices are absorbed. This instrument, which is sometimes of great length, is spirally convoluted when unemployed, but it can be unrolled with great rapidity, and is admirably fitted to explore the tubular corollas and deep-seated nectaries of flowers, for the purpose of extracting their sweet secretions. It is of a cartilaginous substance, and owes its great flexibility to its being composed of numerous rings or trarisverse fibres, bearing some resemblance to the annulose structure of earth-worms and some other animals. It is formed of two distinct pieces, which admit of being separated throughout their whole length. Each of these pieces is traversed longitudinally by a cylindrical tube, and being grooved on their inner side, they form when united another canal in the centre, of a somewhat square form, and wider than either of the two lateral ones. The junction of the two parts is so close that the enclosed tube is perfectly air-tight; and this union is effected by means of an infinite number of filets, resembling the laminæ of a feather, which interlace and adhere to each other. Of these three tubes, the central one alone serves for the influx of the alimentary fluids, the two lateral ones being probably employed in transmitting air in aid of respiration, which, however, is mainly carried on by means of stigmata or lateral pores. The outer extremity of the proboscis is frequently beset with many membranous papillæ, resembling leaflets, which have been regarded by 
some authors as absorbents. From having observed them chiefly in long and slender trunks, Reaumur was led to conceive, that their only use is to render that organ more steady, by affording numerous points of support, and adhering in some degree to the substances into which it is inserted;-an explanation rendered highly probable by the fact, that the long and slender ovipositors of Ichneumons, and many other insects, are generally provided with some pointed projections near the tip, evidently intended for this purpose.-Several of the figures on Plate I. are designed to illustrate the structure of the organ just described. Fig. 9, is a magnified view of the trunk, showing its general form, and the projecting points near the tip $(a)$. Fig. 10, is a highly magnified section, exhibiting the two portions $(a, b)$ of which it is composed, each of them tubular $(d, d)$, and forming by their junction a central canal (e). Fig. 11, is another section, representing the under side.

The two portions of which the proboscis is composed, seem to be analogous to the maxillæ or under jaws of the mandibulated tribes, and to receive their great development at the expense of the other oral appendages, most of which are small and inconspicuous. This is not the case, however, with the labial palpi, which are generally of considerable size, and curved upwards in such a manner as to form two projecting points in front of the head. These organs are covered with hair-like scales, are usually of a somewhat conical shape, and consist, for the most part, of three articulations. (See PI. I. fig. 12, a 
They are attached to a triangular plate, which must be regarded as the labium or under lip, as it closes the cavity of the mouth, immediately below the insertion of the trunk. On each side of the latter, not far from the base, there is a minute tuberculiform projection, formed of two or three indistinct joints, which together seem to represent the maxillary palpi. The representative of the labrum or upper lip, is a minute membranous piece, usually approaching to a triangular shape ; and two other small projections, more or less ciliated internally, and placed one on each side of the proboscis at the base, are analogous to the mandibles of gnawing insects. Most of these parts, however, exist in a very rudimentary condition, and afford another example, in addition to many already familiar to us, of nature adhering to a particular form of structure, after it has ceased to be subservient to any essential function; for, if some of these parts are designed for the same purpose which they serve so effectively when fully developed, it is not easy to see how they could be employed by the insect, or in any way prove serviceable to its economy.

Both the different kinds of eyes which occur among insects, are to be found in the diurnal Lepidoptera. The ordinary, or compound eyes, are large and hemispherical, occupying greater part of the head, and no fewer than 17,325 lenses have been counted in one of them. As each of these crystalline lenses possesses all the properties of a perfect eye, some butterflies may therefore be said, if M. Puget's observations are correct, to have no fewer than 34,650 , 
The stemmatic, or simple eyes, in the form of pellucid spots, are usually two in number, and placed on the crown of the head. They are probably often awanting, and, when present, are so indistinct. from being covered by the hairs and scales that clothe the surface, that their existence in any case among the diurnal Lepidoptera has been sometimes denied.

The antennæ are of moderate length, and consist of a great number of joints, which usually increase in thickness towards the extremity, where they form a club or knob: (Pl. I. fig. 12, b). They are greatly more uniform in appearance and structure than in the coleopterous or most other tribes, or in the nocturnal species of the same order, which often have them bealltifully branched, and plumose. The shape of the terminal knob, however, varies considerably, and as its different forms afford useful characters for distinguishing genera, they will be afterwards particularly indicated.

The thorax - that portion of the body intermediate between the head and abdomen - is composed of three segments, so closely united as apparently to form a single piece. Its most ordinary form approaches to cubical, any apparent deviation from that shape being chiefly caused by the greater length and density of the hairs and scales with which it is covered. Before the insertion of the upper wings, two corneous scales may be observed, covered with tufts of hairs, so as to make them resemble an epaulet: these have received the name of patagia, or 
tippets. The scutellum - a triangular piece in the hinder part of the thorax, which is very conspicuous in beetles and many other tribes - likewise exists in butterflies, but it is very minute, and has its point directed forwards. The thorax is always shorter than the abdomen, and generally more robust, as it supports all the organs of motion, and contains the muscles by which the latter are actuated.

- These important appendages are of course the wings and legs, of which it is necessary to give some account. The latter, as in all other genuine insects, are six in number, and composed of the same amount of pieces as in most of the class. They are inserted pretty close to each other, without any inequality in the size of the intervening spaces. The thigh is often fringed with long hairs, and the tibia is frequently armed with a spur near the middle, and two others at the tip. The tarsi in all the perfect legs are fivejointed, and furnished with two claws at the extremity, which are often bifid. (PI. I. fig. 13.) Many of these insects, however, have the anterior pair of legs imperfect, or not adapted for walking, being too short to reach the plane of position, and usually drawn close to the sides of the thorax, the long hairs of which in a great measure conceal them from our view. These spurious legs have only one joint in the tarsus, which, in some cases (as in Vanessa, \&c.), is without claws; and the species so circumstanced are named tetrapod, or four-footed butterfies.

The wings are of much greater extent, in propor- 
tion to the size of the body, than in any other tribe of insects. The forms which they assume are very various; but the most ordinary shape of the upper pair is triangular, with the apex of the triangle towards the body, while the outline of the under wings approaches to circular. They are traversed by numerous nervures, which give a great degree of strength to the wing, and hold in tension the thin elastic membrane of which it is composed. These nervures are tubular, and are permeated by an aërial and aqueous fluid, the action of which expands the wing when in a moist and corrugated state after the insect has emerged from the pupa. The principal branches rise from the point where the wing is attached to the body, and they divide towards the other extremity into numerous ramifications. The spaces into which the wing is divided by these nervures, are denominated areolets by Kirby and Spence; and these authors regard the upper wings as divisible into three larger longitudinal sections, which they term areas. The costal area occupies the anterior margin: the anal area, a narrow space along the posterior margin; and the intermediate area, all that part of the wing lying between the two others. The most conspicuous areolet in butterflies is towards the centre of the wing, at the base, and is usually closed on its outer side by transverse nervures. In many instances, however, there are no transverse nervures, and all the areolets are open towards the outer side. 
With such an extent of "sail-broad vans," it is easy for butterflies to support themselves for a long time in the air; but their mode of flight, at least in Reaumur's opinion, is generally not very graceful. They seldom fly in a direct line, but advance by rising and falling alternately, in a succession of zig-zags, up and down, and from side to side. By flying in this manner, they are supposed to elude more easily the pursuit of the smaller birds, which often make them a prey. "I one day watched with pleasure," says Reaumur, "a sparrow pursuing a butterfly on the wing for a considerable time, without succeeding in catching it. The flight of the bird was notw withstanding much more rapid than that of the butterfly, but the latter was always either above or below the point to which the bird directed its flight, and at which it expected to seize it." * Many of the species, however, differ so much from each other in their mode of flying, that a practised eye can recognise them by this means alone. Such as are provided with strong wings, exercise a more steady and continuous flight, nearly resembling that of a bird, ascending high into the air, and often making their way against a pretty strong current of wind. Of our British species, the White Admiral is the most celebrated for its manner of flying. "The graceful elegance displayed by this charming species," says Mr Haworth, "when sailing on the wing, is greater,

* Reaumur, Memoires pour servir à l'Histoire des Insectes, i. p. 203. 
perhaps, than can be found in any other we have in Britain. There was an old Aurelian in London, so highly delighted at the inimitable flight of Camilla, that, long after he was unable to pursue her, he used to go to the woods, and sit down on a style, for the sole purpose of feasting his eyes with her fascinating evolutions!"

The hinder section of the body is the abdomen, which presents nothing peculiar in its form or structure. It consists of six or seven segments, and is attached to the posterior part of the thorax by a very small portion of its diameter. It is without any appendage at the extremity, there being nothing analogous to a sting or ovipositor among butterfilies.

Before acquiring their perfect form, these creatures, as is well known, pass through several different states of existence, in which they are distinguished by organs and properties of a wholly dissimilar kind. Of these a somewhat detailed account is necessary, in order to afford any thing like a complete view of their history.

All these insects originate from eggs, which are carefully deposited on the leaves and other parts of plants, by the parent fly, after accomplishing which, she soon dies. These eggs are sometimes placed singly, at other times in groups containing considerable numbers. They are always covered by a coating of varnish, which serves the double purpose of 
attaching them to the plant and defending them from the action of the weather. They differ essentially from the eggs of birds, as no lime enters into their composition, and, instead of being covered with a crustaceous shell, they are merely enveloped by a thin membrane. They are also very unlike each other in different species, whether we regard them in respect to colour, form, or sculpture. Some of them are nearly orbicular or oval, others cylindrical, and not a few conical. The surface is often beautifully carved, as will be seen by the accompanying figures, which represent several varieties, as they appear when highly magnified. Plate I. fig. 3, Egg of Vanessa urtica, with several longitudinal ridges. Fig. 4, Subconical egg of Pontia brassica, with granulated longitudina ribs, connected by elevated cross lines; the colour bright yellow. Fig. 5, Egg of Hipparchia Tithonus. Fig. 6, Of Hipparchia Jurtina, crowned with a series of imbricated scales. Fig. 7, Globular egg of Hipp. Hyperanthus, ornamented with regular rows of minute elevated points. Fig. 8, Egg of Hipp. ageria, having the whole surface covered with hexagonal meshes.

After the fly has fixed her eggs on a plant, she takes no further care of them, but leaves them to be hatched by the heat of the atmosphere. This generally takes place in the course of a few days, but the period varies according to the degree of warmth to which they are subjected, and the greater or less density of the shell or outer covering. Such, indeed, 
as are laid late in autumn, do not produce their caterpillars till the ensuing spring. Tn facilitate the egress of the young larvæ, the eggs of some species are furnished with a kind of lid at one end, which is pushed outwards by the pressure of the head.

Guided by an instinct which must excite the admiration of every reflecting mind, the butterfly, however herself regardless of such pasture, never fails to place her eggs either upon the plant which is to afford sustenance to her infant progeny, or in its immediate vicinity; so that, upon their first exclusion, hey are surrounded by their appropriate food. Upon issuing from the egg, the young larvæ appear as small cylindrical worms ; but their growth is rapid, and no very lengthened period elapses before they attain their full dimensions. It is in this state that they are termed caterpillars, a name which they probably owe to their voracious habits.* They are the most destructive of all the smaller animals to living vegetation, and their ravages are sometimes so extensive, as not only to occasion considerable loss to the gardener and agriculturist, but even to render

- The origin of this word is not very obvious, but it no doubt refers to their destructive propensities. The most probable derivation is that which assigns it to the two old French words, acat, food or provisions, more recently written cates, as in Paradise Lost,

........alas! how simple to these cates

Was the crude apple that diverted Eve!

and piller, to rob or plunder, whence also we have the word pillage. 
unsightly the otherwise umbrageous trees of the forest, by consuming their leafy verdure. Almost their only employment, indeed, is to eat; and so industrious are they at this agreeable occupation, that they often consume, in the course of twenty-four hours, double their own weight of food - a degree of voracity of which we find no example among the higher animals. Their structure is admirably adapted to their mode of life; and their singular habits and economy render them even more interesting objects of observation in this preparatory state, than after they have assumed their more perfect and imposing form, when,

No longer reptile but endowed with plumes, They through the blue air wander.

The body of caterpillars is long and nearly cylindrical, and is divided, by deep incisions, into twelve segments, exclusive of the head. The outer integument, or skin, is usually membranous and soft, but in some instances it approaches more to a coriaceous texture. The general softness of the body is of great utility, as it thereby acquires great flexibility, and readily accommodates itself to the various curves and inflections which the insect is continually giving to it, and which are rendered necessary from the manner in which it obtains its food. Most of the caterpillars that produce day-flying Lepidoptera, have sixteen legs, which are of two distinct kinds. Six of them are placed on the three anterior segments - that portion of the body which corresponds to 


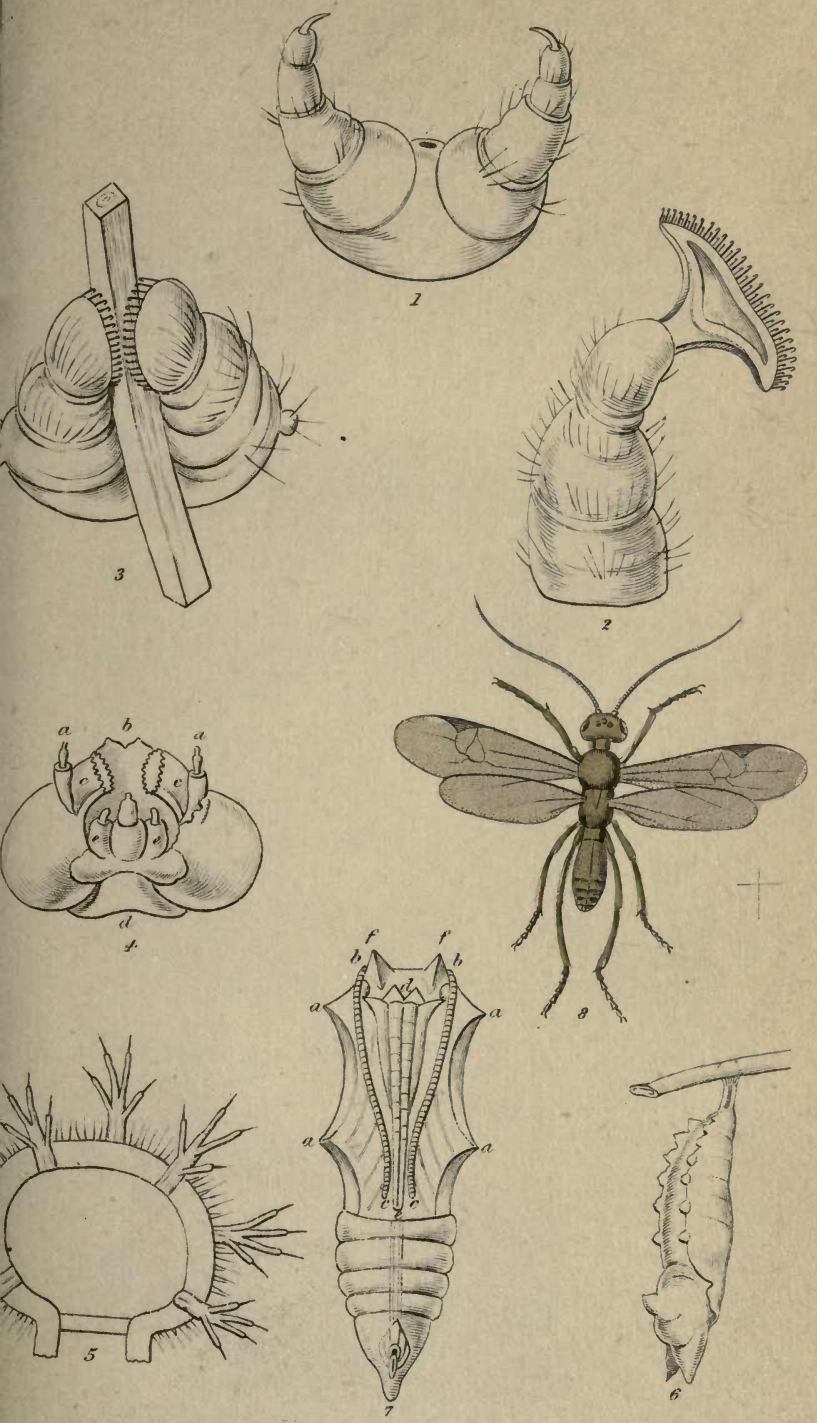


the thorax of the winged insect - and the others are attached to the sixth, seventh, eighth, ninth, and anal segments. The form of the anterior or thoracic legs is wholly unlike that of the others, and they seem to be the principal instruments of locomotion. They are of a horny substance, wide at the base, and gradually growing narrower to the lower extremity, where they terminate in a strong claw. Each of them is divided into several segments, which correspond to the different parts that compose the leg of the future fly. (Plate II. fig. 1 , represents a pair of these legs). The other legs, attached to the hinder or abdominal portion of the body, are soft and fleshy, and therefore have been called the membranous legs, or pro-legs. Their principal use is to support the bo$\mathrm{dy}$, by adhering to the slender twigs and shoots which the animals frequent to procure their food. For this purpose they can be lengthened and shortened at pleasure, and can even be drawn almost within the body, like the horns of a snail. Their general figure approaches to that of a truncated cone, which is terminated by a fleshy foot of a construction peculiarly fitted to cling to a smooth surface, or embrace a slender twig. What may be called the sole of the foot, expands into a somewhat triangular plate, which is furnished on its inner edge with a row of small horny hooks or claws, consisting of a short and long one alternately, forming, as Reaumur remarks, a kind of palisade round part of the circumference. When the disk, or central plate of 
the foot, is dilated, these claws are turned outwards, and their small curved points find inequalities to which they can adhere even on a surface which might appear to the naked eye almost smooth. Several modifications of this curious prehensile foot occur among the larvæ of various kinds of moths; but of these it forms no part of our present purpose to give an account. (Plate II. fig. 2, Represents the proleg of the caterpillar of a butterfy, from Reaumur. Fig. 3, A pair of pro-legs, shewing the manner in which they cling to a branch).

The head of caterpillars is of a harder-consistence than the rest of the body, and in most cases seems to be composed of two oval lobes united. In that of the Purple Highflier, these lobes are produced behind into two rather long occipital horns. (Plate III. fig. 6). The conformation of the mouth of lepidopterous larvæ in general, bears considerable resemblance to that of several masticating insects in their perfect state. See Plate II. fig. 4, which represents the under side of the head of a caterpillar.) It consists of an upper lip, with a deep notch in the centre (b); two strong mandibles divided at the tip into numerous sharp teeth, which cut the leaves that serve as food $(c, c)$; two small and indistinct organs of a soft consistence, lying under the mandibles, which may be regarded as the maxillæ; and an under lip $(d)$. Near the summit of the latter, which is usually of a pyramidal shape, is placed, according to Reaumur, a small conical protuberance, perforated 
by a small hole, through which issues the silken thread which serves so many important purposes in the remarkable changes these creatures undergo. This organ has been named the spinneret.- On each side of the under lip, and connected with it at the base, are two minute palpiform bodies $(e, e)$, which may be regarded as the labial palpi.

The efficiency of the organs just described, is well evinced by the address and rapidity with which these creatures consume the leaves which they select for their food. They invariably begin to gnaw the margin of the leaf, placing the body in such a position that a portion of the edge passes between the anterior legs, which support and keep it steady. Before applying its mouth, the caterpillar stretches its body, and advances its head as far as possible, that it may command a larger extent of the leaf. The mandibles are moved with great rapidity, and every time they meet cut off a small piece, which is instantly swallowed. At every motion of the jaws, the head is drawn nearer the legs, and after it has been brought as far as possible, the body being contracted for the purpose, it is again extended to the point where it commenced to gnaw, and the same process repeated. In this manner the mandibles describe a succession of arcs, and the leaf is cut in the segment of a circle, somewhat resembling the circular incision made by the leaf-cutting bees. It seems, also, that the notch in the middle of the upper lip, formerly alluded to, is of great service, as it is placed on a line with the 
place where the jaws unite, and serves as a groove, both to give steadiness to the margin of the leaf, and to guide it in the direction most favourable for the jaws to act upon it.

The only remaining organs to which it is neces. sary to allude, are the eyes and antennæ. The former appear as small dark-coloured points, arranged in two circles, containing six each, on the anterior part of the head. These points vary in size, and seem to be of the same nature as the simple eyes of spiders, and the stemmata of various kinds of insects. The antennæ, often the most conspicuous appendages of the head in perfect insects, are very minute in lepidopterous larvæ, usually consisting of two or three short joints. They are almost always of a conical form, and many species have the power of drawing the joints within each other, like the tubes of a telescope, till they are wholly concealed.

Many caterpillars of the day-flying Lepidoptera are smooth on the surface, or covered only with a very short matted pubescence; but in some cases they are furnished with rigid hairs, and numerous long spines. These hairs are sometimes simple, but more commonly they have a series of small pointed pieces springing from each side, like leaves from a stem. They are seldom planted irregularly over the surface of the skin, but usually issue from a tubercle, and diverge in all directions. These tubercular elevations vary greatly is number, and are placed in a 
row across the middle of the segments. The spinous caterpillars indigenous to Britain are but little remarkable when compared with many exotic species, but we have several which afford good examples of this description of defensive armour; such, for instance, as the very common kinds that feed on the nettle. In these, and most other instances, the spines are sufficiently strong and sharp as readily to pierce the skin of the hand. They are very often beset with hairs, and frequently divide towards the top into several small branches. Even when so numerous as entirely to cover the body, they are not placed promiscuously, but arranged, like the tubercles formerly mentioned, in a certain order. Each segment, with the frequent exception of that next the head, is armed with a transverse series, varying in number from four to eight. The accompanying figure represents a magnified section of the caterpillar of Cynthi Cardui, exhibiting the number, mode of arrangement, and structure of the spines. (Plate II. fig. 5.) These appendages, in many foreign caterpillars, are said to sting like a nettle; and there can be no doubt, that, in all cases, they are a powerful means of defence, not only against the smaller birds, * but even against more formidable enemies.

* Few birds prey upon hairy caterpillars, although the Cuckoo which is extremely fond of the larvæ of Arctia caja (called par excellence the hairy-worm) forms an exceptio to the rule. 
The history of insects, fruitful as it is in all itg branches, in instances of nice adaptations and ingenious mechanism, presents few topics more deserving of consideration than are afforded by the proceedings of these caterpillars when they change their skin, and when they prepare to enter upon that dormant state which precedes the development of the perfect fly. The proximate cause of the moulting or change of skin, is the internal growth of the body, which thus becomes too bulky for the envelope in which it is enclosed. The latter can scarcely be said to grow, but is merely capable of being dilated to a certain point, after which it offers so much resistance to the expansion of the enclosed animal, that it becomes necessary to throw it off entirely. It must be evident, however, that it is no easy task to withdraw the body from a shell in which every separate limb and articulation is closely encased, without any assistance being derived from without. This, however, the animal accomplishes so adroitly, that the cast-off skin appears almost entire, and even retains all the spines and other appendages with which it may have been furnished. The operation, which seems to be a painful one, and even at times attended with fatal consequences, is thus described by Reaumur:-

A day or two before the critical moment arrives, the caterpillars cease to eat, and become very inactive, usually remaining stationary on a single spot. They select some place where they may be in greater 
security, and seldom leave it even though disturbed. Although weak and languid, they are continuaily giving various movements to the body, but without shifting their station. The back is sometimes bent outwards, and soon after resumes its natural position, and the head is elevated, and speedily drawn down again. At other times, the anterior part of the body makes two or three very rapid vibrations to the right or left; while less perceptible motions are communicated to the different rings, some of which are considerably dilated, and others contracted. The effect of these alternate swellings and contractions soon becomes apparent, for the outer skin, now rendered dry and rigid, by the subtraction of the juices by which it was previously nourished, begins to split on the back of the second or third segment, and discloses a portion of the new integument. The rent being once commenced, is easily extended by the dilatation of the body, from the first to the fourth segment, and thus leaves a considerable part of the back uncovered. This part of the body is no sooner free than it is curved upwards, a movement by which the head is disengaged from its old envelope, and raised through the fissure. The head is then reclined on the case that formerly contained it, and nothing remains but to withdraw the hinder part of the body, which is done by contracting the segments, and drawing them towards the head till they reach the opening.

All these operations, apparently so laborious, are 
accomplished in a very short time. As if exhausted by its efforts, the caterpillar continues for a while in a state of inactivity, till the moisture evaporate from its skin, and the newly exposed parts become sufficiently consolidated. The colours which, before moulting, were pale and indistinct, soon become bright and well defined, and are often distributed in a manner different from those which adorned the rejected covering. Its strength and activity are soon restored, and the renovated animal,

Nunc positis novus exuviis, nitidusque juventa,

returns to its wonted occupation with even greater voracity than before.

These changes take place at least three different times before the caterpillar attains its full maturity; and in many instances, it is probable that there are not fewer than five or six moults. After continuing in their reptile form for a longer or shorter period, according to the species, they prepare to enter upon a new state of existence, distinguished by attributes very dissimilar to those they previously possessed. This important and singular metamorphosis, by which a long cylindrical worm, possessing all the necessary organs of motion and nutrition, and employing these with the utmost activity, is converted into an inert mass, without external organs, and incapable of locomotion, or of receiving food, is preceded by some preparations similar to those that attend a change of skin. As if foreseeing its ap- 
proaching incapacity either to defend itself or to flee from danger, the caterpillar, having now completed its full growth, generally abandons the plant on which it fed, and seeks a secure retreat, or some fixed and stable object to which it may adhere. It is in consequence of this precaution that we so often find chrysalides in the holes of old buildings, in the fissures of timber, \&c. or attached to walls, posts, and trees, as the latter afford more permanent security than the weak and perishable herbaceous plants which so many caterpillars frequent during their voracious days. Having selected a proper place, the animal commences its curious proceedings, which terminate in the ejection of its skin, the evolution of the chrysalis, and the suspension of the latter by means of a cord of silk. As chrysalides are sus. pended in two different ways, either perpendicularly by the tail, or horizontally by means of a band round the middle, the proceedings of the caterpillars necessarily vary accordingly, and it will therefore be requisite to advert successively to each.

When the chrysalis is to be suspended by the tail with the head downwards, the first operation of the caterpillar is to cover a portion of the surface to which it is to attach itself with a layer of silken threads, which readily adhere in consequence of their viscosity. Each successive layer covers a smaller space than that which preceded it, so that they form, when completed, a little hillock of silk, approaching to the figure of a reversed cone. Into 
this the animal pushes its hinder pair of pro-legs, which immediately get entangled among the threads by the small hooks which project from a part of the outer edge of the foot. (Plate II. fig. 2.) The anterior part of the body is then permitted to fall down, and it therefore hangs in a vertical position, with the head lowest. Soon after, it begins to bend the head upwards, in such a manner that the convexity of the curve is formed by the back: it retains this position for a considerable time, then allows the head to fall down, and again bends itself, always taking care to do so in one direction. After this process has been continued for some time, occasionally not less than twenty-four hours, and in one instance mentioned by Reaumur, it lasted for two whole days, the skin rends in the back, and a portion of the chrysalis projects from the opening. The latter is gradually enlarged by the pressure and swelling of the chrysalis, which acts as a wedge, both in splitting the skin and in pushing it upwards to the tail. By alternate contractions and expansions, the head, or lower portion of the chrysalis, becomes wholly disengaged; and the skin of the caterpillar, now dry and shrivelled, is pressed together into a small bundle which surrounds the tail of the chrysalis. This, however, is still the only means of support, and the difficult task which yet remains for the chrysalis to perform, is to extricate itself from the skin, and suspend itself to the silken mooring, which is now considerably above it. In order to accomplish this, which seems to require an effort beyond the 
power of a creature unprovided with arms or legs, it seizes on a portion of the skin between two segments, holding it as with a pair of pincers, and thus supports itself till it withdraw the tail from its sheath. It then elongates the rings of its tail as much as possible, and seizes a higher portion of the skin, repeating the same manœuvre till the extremity touch the hillock of silk, to which it immediately adheres by means of a number of hooks with which it is provided for the purpose. "These operations of withdrawing the tail from its case," says Reaumur, to whom we have been chiefly indebted for the preceding account, " climbing up the skin, and finally attaching the extremity to the silken web, are very delicate and perilous manœurres. It is impossible not to wonder, that an insect which executes them but once in its life, should execute them so well. We must necessarily conclude that it has been instructed by a Great MAster ; for he who has rendered it necessary for the insect to undergo this change, has likewise given it all the requisite means for accomplishing it in safety." * In order to get quit of the slough, which is still suspended by its side, the chrysalis curves its tail in such a manner as partly to embrace it, and then, by whirling rapidly round, sometimes not fewer than twenty times, and jerking suddenly against it, it generally succeeds in disengaging it trom its fastenings, and throws it to the ground.

- Reaumur, vol. i. p. $423,424$. 
When the chrysalis is to be suspended horizontally, or in an inclined position, the caterpillar commences, as before, by fixing its hinder pro-legs to a button of silk spun for the purpose. But as some additional support is necessary in this case, it prepares a band of the same material for encircling its body near the middle. Different methods are practised by caterpillars for fixing this cincture. The most simple, and least liable to accidents, is that adopted by the larva of the common Cabbage Butterfly, and other allied species. Availing themselves of the great flexibility of their bodies, they bend the head backwards to the point where the girdle is to be placed, and, after fixing the threads on one side, carry them over to the other, merely by turning the head in the opposite direction. Other caterpillars, of which that of the Swallow-tail (P. Machaon, Pl. III. fig. 1.) may serve as an example, spin their suspensory band, and fasten it at each end, allowing it to hang down in a loop, into which they insinuate their bodies after it is completed. But the threads not being agglutinated, or twisted into a compact cord, the creature could scarcely avoid being entangled among them in its passage, but for the dexterous use it makes of its fore-legs, which it employs to keep the band extended and in a proper position.

Some time after the caterpillar has been thus attached to the under side of a branch, or some other object, the skin is cast nearly in the same manner as formerly described, being ruptured on the back 


$$
\text { 永 }
$$







by the contortions and annular contractions of tne animal, while the band is too loosely girt to form any material hinderance to its being slipped downwards to the tail, where it is ultimately thrown off altogether.

When the chrysalis is first disclosed it is soft anci tender, and covered with a viscid transparent liquor, through which many portions of the future butterfly may be pretty distinctly discerned. As this liquor dries, it acquires the consistency of an opaque membrane, which envelopes all the parts, binding them more firmly together, and forming a protection from the weather. It so closely encases the different limbs and organs, that the disposition of many of them can be traced by the ridges and other prominences they form on the surface. This will be seen by the accompanying figures of the chrysalis of the larger Tortoise-shell Butterfy ( $V$. polychloros), which may likewise serve to exemplify the general appearance of the diurnal Lepidoptera in their pupa state. Plate II. fig. 6, represents the natural size of the chrysalis, which is one of those distinguished by a kind of mask, in which some authors have had the ingenuity to discover a striking resemblance to the human countenance. Fig. 7, a magnified view of its under side: $a, a$, the wing-cases (Ptero-theca, Kirby); $b c, b c$, the antennæ; $d e$, the trunk or sucker; $f, f$, two trigonal pieces, forming the eyecases. In consequence of their being so completely unclosed by this rigid integument, Linné termed these 
pupæ obtected. In this state, they are of course in. capable of moving from the place to which they are fixed, and indeed of making a movement of any kind, save twisting the abdomen to one side, which they generally do when disturbed. Scarcely any other symptom of animation is perceptible, but during the continuance of this apparent torpor some important changes are taking place internally. The milky fluid which at first filled nearly the whole of the interior, is gradually absorbed and assimilated by the growing embryo, while the watery portions pass off by evaporation. In this way the germ of the future fly is enlarged and matured, till it ultimately fill the whole cavity of the puparium or pupa-case. The process of respiration is likewise carried on, though to all appearance in a very languid manner, through the medium of a series of spiracles or air-holes placed on the sides of the abdominal segments.

The greater number of butterfly chrysalides are of an angular figure, wide and obtuse at the head, and tapering to the tail in the form of a cone. Besides having various angular projections on different parts of the surface, the head terminates in a conical projection, which is very frequently double. In a pretty extensive group, however, (comprising the genera Thecla, Lycæna, \&c.) the chrysalides are without any protuberancé, and of a conical shape, the anterior extremity being simply rounded. The prevailing colour is brown, often inclining to black; but, in some instances, they are adorned with very 
agreeable hues. Those of the Swallow-tail and Purple Emperor are of a fine green, resembling their respective caterpillars : the ground colour of that of the common Cabbage Butterfly is greenish-yellow, marked with small black points, somewhat arranged in lines; while that of the Black-veined White (Plate III. fig. 4.) is yellow, streaked and spotted with black. But many chrysalides are decorated in a more sumptuous manner, some of them appearing entirely covered, and others spotted with goldenyellow of the highest metallic lustre. It is this colour which caused the Greek name Chrysalis, and the Latin one Aurelia, to be applied to the kinds so distinguished, although these terms are now used indiscriminately in relation to the whole. Among British chrysalides, the kinds that exhibit most of this metallic brilliancy, are those that produce flies belonging to the genera Argynnis and Vanessa. That it is not a superficial application, is proved by its disappearing as soon as the enclosed fly escapes. The observations of Reaumur have shewn that it is owing to the transparency of the outer skin, which is of a yellow colour, and gives a golden tinge to a shining white membrane lying immediately beneath it. A similar effect is sometimes produced by artificial means.

The duration of the pupa state varies greatly in different species, and even in the same species, according to circumstances. Thus, the chrysalis of the Swallow-tail Butterfly (P. Machaon), when the 
caterpillar enters upon that state in July, produces the butterfy in thirteen days; but when the chrysalis is formed in the end of autumn, the perfect insect is not evolved till the succeeding June. Suck variations were conjectured by Reaumur to depend on the temperature to which the chrysalides are exposed; and he proved this to be the fact by a series of very simple and conclusive experiments. By placing a variety of chrysalides in an atmosphere artificially heated, he succeeded in bringing out several broods of butterflies in the very middle of winter, which, if left to natural influences, would not have appeared till the ensuing summer. He found that when the temperature was rather high, the chrysalides made as much progress to maturity in five or six days as they would have done in ordinary circumstances in an equal number of weeks. Having thus proved the influence of heat in hastening the exclusion of these insects, he next tried the effect of cold in retarding it; and the result was equally satisfactory. He preserved several pupæ from heat, by keeping them during summer in an icehouse, in consequence of which the butterflies were not disclosed till a year after their ordinary and natural time.*

When the butterfly is fully matured, it extricates itself from the puparium, by bursting that portion of it which covers the thorax, an operation which is easily accomplished, as the membrane has by that time become weak and friable. On its first exclusion, it

- Reaumur, ii. 10. 
is feeble and languid, and usually fixes itself on the exuviæ from which it has just emerged, or on some neighbouring object, till it acquire some degree of strength. All the parts are soft at first, and covered with moisture, but this speedily evaporates, the organs become firm, and every symptom of debility soon disappears. In this process, the development of the wings is not the least interesting object. $\mathrm{Hi}$ therto compressed within a very narrow space, they at first appear as small crumpled packets, affording no indication of the extension and beauty which they ultimately acquire. But their folds and corrugations soon begin to give way to the pressure of the nervures, which are tubular vessels ramifying through the whole extent of the wing, and which are them. selves excited and dilated by having an aqueous fluid impelled into them from the trunk of the insect. As the nervures diverge, the interjacent spaces gradually become tense, the animal assisting greatly in extricating the folds, by frequently shaking its wings with a tremulous motion. The spots and other markings are by degrees unfolded, and after the expanded wings have been for a short time exposed to the sun, the new-born fly launches into the air witb as much apparent ease and confidence as if it had been long familiar with such an exercise.

The appearance of these creatures in their various states of caterpillar, pupa, and butterfly, is so strikingly dissimilar, that it was long a general belief that they underwent, at each successive stage, a complete 
transmutation, or change from one being to another Such an opinion presented no difficulties to those who, like Virgil, imagined that a swarm of honeybees might be generated from a piece of putrid flesh; or, like Kircher, that a crop of serpents might be reared from cut pieces of snakes, roasted, and sown in an " oleaginous soil ;" and may even now seem not untenable by such as believe that a horse-hair placed in the water of a spring, will, in process of time, be transformed into a hair-worm, or young eel! The accurate investigations of Malpighi and Swammerdam were the first to show this subject in its true light, by demonstrating in what the transformations of butterflies essentially consist. By the dissection of caterpillars - an operation which they performed with astonishing skill and delicacy - they were able to discover the parts of the future butterfly folded up within the body, in the same manner as an embryo flower may be detected in the interior of an unexpanded bud. "It is clearly and distinctly seen," says Swammerdam, " that within the skin of the caterpillar a perfect and real butterfly is hidden, and therefore the skin of the caterpillar must be considered only as an outer garment, containing in it parts belonging to the nature of a butterfly which have grown under its defence by slow degrees, in like manner as other sensitive bodies increase by accretion." * In every caterpillar, therefore, there exists, from the earliest period of its life, the germ

- Book of Nature, ii. 26. 
of the future fly, which is gradually developed by the accretion of new matter; and its various envelopes are thrown off as they successively become su. perficial, till it is fully matured and perfected. When in the state of pupa, the embryo having then advanced another stage towards completion, the parts of the perfect insect are even more easily discerned than in the previous condition; and for some time before the final change they may even be perceived through the membrane in which they are enclosed.

Even when viewed in this light, as a series of de. relopments without any absolute change of identity, the metamorphoses of these creatures are sufficiently wonderful to be ranked among the most remarkable and interesting natural operations with which we are acquainted. So striking did they appear to the ancients, that they regarded the butterfly as affording a most lively and beautiful emblem of the soul; and according to this idea, the Greeks often used the word $P$ syche, which properly means the human soul, to signify also a butterfly. With greatly more accurate notions of the real nature of these transformations, few modern writers on the subject have failed to notice and dilate upon the general symbolical analogy which subsists between them and the changes which the human body is destined to undergo. The caterpillar-chiefly occupied in providing for its bodily wants and appetites - is regarded as representing the ordinary condition of human life : the chrysalis the intermediate state of death; 
and the perfect animal, the renovated body when it rises from the tomb to enter upon a more exalted state of existence. "But although the analogy between the different states of insects and those of the body of man is only general, yet it is much more complete with respect to his soul. He first appears in this frail body, a child of the earth, a crawling worm, his soul being in a course of training and preparation for a more perfect and glorious existence. When it has finished this course, it casts off this vile body, and goes into a hidden state of being in Hades, where it rests from its works, and is prepared for its final consummation. The time for this being arrived, it comes forth with a glorious body, not like its former, though germinating from it; for though " it was sown an animal body, it shall be raised a spiritual borly," endowed with augmented powers, faculties, and privileges, commensurate to its new and happy state. And here the parallel holds porfectly true between the insect and the man. The butterfly, the representative of the soul, is prepared in the larva for its future state of glory; and if it be not destroyed by the ichneumons, and other ene. mies to which it is exposed, symbolical of the vices that destroy the spiritual life of the soul, it will come to its state of repose in the pupa, which is its Hades ; and at length, when it assumes the imago, break forth with new powers and beauty to its final glory and reign of love. So that in this view of the sub. ject, well might the Italian poet exclaim, 


\section{INTRODUCTION.}

Non $v^{\prime}$ accorgete voi, che noi siam' verm

Nati a formar l' angelica farfalla ?" *

Lepidopterous insects, like most others of their class, are liable to be attacked by various parasitical assailants, which effect a lodgment in the interior of their bodies, the substance of which they speedily consume, and thereby destroy them in great numbers. In none of their different stages are they exempt from these attacks, excepting perhaps in their winged state; but they are particularly exposed to them when caterpillars. The parasites are hymenopterous flies belonging to the genus Ichneumon of Linnæus; and perhaps the most destructive are those minute kinds which compose the modern generic group named Microgaster. As an example of the latter, we have represented the species which destroys the caterpillar of the common Cabbage Butterfly: it is the Ichneumon glomeratus of Linn. (Plate II. fig. 8, greatly magnified.) The size is very diminutive, the largest specimen seldom exceeding two lines in length. The general colour of the body is deep black, and the legs reddish-yellow. The wings are somewhat longer than the body, and pubescent, each of the upper pair having a triangular black spot near the middle of the anterior margin (the stigma), three discoidal cells, and a triangular areolet, rather imperfectly formed. The abdomen is furnished with an ovipositor, consisting of two flat valves, and a curved horny sheath, terminating in a point. The

- Introd. to Entomology, i. p. 76. 
use of this instrument is to pierce the skin of the caterpillar, and to form a conduit for conveying the . eggs into the hole thus prepared for their reception. When the fly has selected a caterpillar fitted for her purpose, she alights upon its back, and plunges her weapon into its body, chiefly at the incisures of the segments, depositing an egg at every insertion. This operation is repeated till no fewer than thirty or forty eggs are sometimes laid in the body of a single caterpillar. These are soon hatched in their singular nidus, and the grubs which they produce immediately begin to feed on the substance of the living animal. They do not, however, devour every part indiscriminately, but are taught by a wonderful instinct to abstain from injuring any vital organ, as if aware that their own existence depended upon that of iheir unwilling foster-parent. In consequence of this, the caterpillars survive for a considerable time, and sometimes retain sufficient strength to assume the pupa state, in which, however, they invariably perish. But most frequently the grubs arrive at maturity before that change takes place, and in that case they escape from the body of the caterpillar by gnawing a passage through its sides. Having in this way effected their liberation, they arrange themseives round the sides of the caterpillar, which is now so exhausted that it soon dies, and spin cocoons of a fine yellow colour, in which they are transformed into pupx. When the perfect fly is ready to emerge, it pushes open a small lid at one end of the cocoon, 
and after it has been for a short time exposed to the air, it is ready for flight.

Other minute ichneumons deposit their offspring in the eggs, or in the pupa of butterflies, and such numbers are destroyed in this way, that it is evidently one of the means employed by Providence to keep within due limits a tribe of creatures which, if left to propagate without restriction, would occasion incalculable mischief, by destroying almost every kind of regetable produce.

Having thus attempted to sketch the general history of Butterflies, a subject of sufficient extent to admit of much further detail, we now proceed to describe the species which have been ascertained to inhabit Britain, reserving such additional historical notices as may be necessary for the full elucidation of the subject, till we come to treat of the genera and species to which they respectively refer. 
Lo! the bright train their radiant wings unfold, With silver fringed, and freckled o'er with gold. On the gay bosom of some fragrant flower, They idly fluttering live their little hour, Their life all pleasure, and their task all play, All spring their age, and sunshine all their day.

Barbauld.

\section{Geves PAPILIO.}

The word Papilio was used by Linnæus in the comprehensive sense which he was accustomed to attach to such terms, to designate generically all the diurnal Lepidoptera. As the amount of known species increased, and their structural differences were more carefully noted, they were arranged in numerous generic groups, both for the purpose of affording a more accurate view of their affinities, and facilitating the identification of species. The original term thus became greatl testricted in its application, and is now confised to ouch butterflies as present the following maracters:- Antennæ rather long, with a slightly cur $\cdots$ d club, which is not compressed, and of an ovate form, terminating in a point : palpi short, not projecting beyond the head, the third or terminal joint minute and indistinct: legs all formed for walking, the hinder tibiæ with two small 
spines at the apex, and the claws undivided: hinder wings scolloped, and furnished with a long narrow projecting lobe like a tail; their interior edge concave or grooved, to receive the abdomen. The caterpillars are smonth and naked, and often ornamented with very veautiful coiours. They have the power of protruding from the neck a soft fleshy horn, which divides near the middle into two branches, like the letter $\mathrm{Y}$. This appendage might be supposed to serve the same end as the horns of the snail, to which it bears much resemblance, but, unlike that animal, the caterpillars are said to push it forth only when alarmed, and it has therefore been regarded as a means of defence, the more especially since it diffuses a penetrating and disagreeable odour. The caterpillar of $P$. Machaon, with the horns exserted, is represented on Plate III. fig. 1.

The chrysalis is angular, and fixed by a silken band round the middle.

These insects composed the section which Linnæus distinguished by the name of Equites. Nearly 200 species have been described, many of which are the largest papilionaceous insects known, and remarkable for the variety and richness of their colours. They abound in the tropical regions of both hemispheres, but occur very sparingly in temperate climates. Besides the two which we have figured, only one other species is known to inhabit Europe, viz. $P$. Alexanor, which, though observed of late years more frequently than formerly, is still extremely rare. 
94

\section{SWALLOW-TAIL BUTTERFLY.}

Papilio Machaon.

PLATE IV. Fig. 1.

inn. Donovan, vi. 75, pl. 211.-Lewin's Insects of Great Britain, pl. 34.

Thrs elegant insect is the largest of our indigenous butterflies, the female being sometimes found to measure upwards of three inches and a half between the tips of the wings. The base of the upper wings is black, powdered with yellow; a large portion of the apex is of the same colour, and adorned with a row of eight semicircular yellow spots, parallel with the outer margin, which is narrowly edged with yellow: the central portion of the wings is yellow, spotted with black, the latter colour forming three large patches towards the anterior margin, and running in a broad line along the nervures. The basal half of the under wings is yellow, except the inner side, which is black, and covered with yellow a airs, and the curved nervure on the under side of the discoidal cell, which is defined by a black streak : the other nervures are dusky. Beyond the yellow portion there is a broad black band, ornamented with 







\section{CALIFORNIA.}


a series of imperfectly defined blue spots, and a row of six large yellow crescents externaily; the outer edge is also yellow, interrupted with black at the nervures. On the hinder angle of each of the under wings there is a large round spot of red, streaked with light blue anteriorly, and nearly surrounded by a black ring. The under side resembles the upper, the most considerable differences being in the yellow outer border of the upper wings, and the presence of two or three faint red spots behind the discoidal cell, and another on the outer edge of the under wings. The body is black above, and clothed with yellow hairs, the latter forming a line on each side of the thorax; the under parts are chiefly yellow.

The caterpillar is not of large size compared with the perfect insect. It is smooth, of a greenish colour, with the incisures and a band on each segment deep black, spotted with red; the retractile organ on the neck of the latter colour. * (Plate III. fig. 1.) It is a solitary feeder, and usually frequents umbelliferous plants, preferring fennel, and the wild carrot. It also feeds on the latter plant in a cultivated state, and sometimes occasions considerable injury to it in France, where the insect if very common, and hence known in certain districts by the name of Grand Carottier. The chrysalis is green, with a streak of yellow along each side, and an irregular row of yellow spots on the back.

- For an accurate and more detailed description, re ference may be made to Ray's Hist. Insect. p. 111. 1. 
Although somewhat local in Britain, this species seems to be pretty widely distributed throughout the southern parts of England, and has been found as far north as Beverley in Yorkshire. It probably does not extend beyond that place, as it certainly has never been observed in Scotland; nor have we heard of its occurrence in Ireland. The fenny districts of Cambridgeshire produce it in considerable abundance; it has been often found in Norfolk, and occasionally in Hampshire and Middlesex. Ray observed it both in Sussex and Essex; and in the days of Wilkes (who has given a good representation of the caterpillar), it was rather pleutiful near Westram in Kent. It is generally diffused over the continent of Europe : it occurs plentifully in Egypt and Syria; and specimens are said to have been brought to this country from the Himalayan mountains. It appears in this country about the end of May, and sometimes continues till the middle of August. 




SCARCE SWAI.IOW.TAII, BUTTERFI,Y.

Pupilio Podalirius.

PLATE IV. Fig. 2.

Linn.-Donovan, iv. 1, Pl. 109._Lewin, Pl. 35.

THE ground colour in this conspicuous insect is yellow ; the anterior edge and outer margin of the upper wings are black, and there are six transverse tapering bands of the same colour on each, the third and fifth from the base scarcely reaching the middle, and the fourth and sixth not extending to the hinder maryin. The under wings are likewise marked with several parallel black streaks; a large portion of the hinder extremity, as well as the elongated tail, are of the same colour, and there is a series of large blue crescents near the margin, which is itself edged with yellow. The anal angle of each of the hinder wings is ornamented with a red spot, bounded in front by a llack crescent, and behind by an oval black spot bearing a curved streak of blue. The markings on the under side do not differ materially from those of the surface, the principal difference consisting in a reddish line between the two largest bars on the under wings. The body is vellow black on the 
back, and having a row of black spots on each side of the abdomen.

The caterpillar is widest at the head, and tapers considerably to the hinder extremity. It is smooth, of a bright green colour, with three longitudinal white imes, and incistinct opiique wnite streaks, spotted with red on each side of all the segments, except that next the head and tail. It feeds chiefly on the various species of the genus Prunus, seeming to be most partial to the sloe-thorn.*

Numerous notices are on record of this species having occurred in Britain, but all of them have been found, on strict investigation, to be of so unsatisfac. tory a nature, as to leave it in some measure doubtful whether it is really indigenous. In some instances, the preceding inseet appears to have been mistaken for it; and in others, examples have been introduced into collections as British, without that fact having been fully ascertairied. Mention is first made of it by Ray, who states that he found it during his tour in Italy; and also, if he recollected rightly ( $n$ i male memini, is the expression) in England. Berkenhout has admitted it into his Synopsis; and it is figured by Donovan, Lewin, and others, among our native species. In a list of rare British Insects, published in 1827, there is an announcement of its having been discovered in the New Forest; but subsequent in-

* Mr Stephens, following Fabricius, says that its fond consiets of the different kinds of brassica; but this statement is at variance with recent and more accurate observation. 
quiry has thrown suspicion on the authenticity of this account. The Rev. F. W. Hope informs Mr Stephens (Illus. of Brit. Ent. 145), that he possesses a specimen of $P$. Podalirius which was taken at Netley, Salop. This statement nas not, as far as we know, been controverted, and seems to form the only unexceptionable authority for regarding the insect as an inhabitant of this country. It is very rommon in some parts of France, where it is named Le Flambe, from a supposed resemblance in the pyramidal shape of the black stripes to the form of flames. 


\section{BRTMSTONE BUTTERFLY.}

Gonepteryx Rhamni.

\section{PLATE V. Fig. 1.}

Pap. Rhamni, Linn.-Donovan, v. 1, Pl. 145.

THIs insect, and a few others, were first former into a distinct genus by Dr Leach, on account of the peculiar shape of the wings, which are large and angulated.* The antennæ are rather short and robust, thickening gradually near the summit into an obtuse club: the palpi project a little beyond the head, and are compressed, the radical joint longest and curved, the terminal one minute and conical : all the legs are perfect, and alike in both sexes; the claws bifid (Pl. I. fig. 13.). Under wings grooved to receive the abdomen.

The male is entirely bright sulphur-yellow above, and the female greenish-white, both sexes with a small round orange spot near the middle of each wing, those on the upper wings being smallest, and a few minute rust-coloured dots along the outer edge. The under side is paler than the upper, and the central spots rust-brown round the margin, and

* Named from yovos an angle, and rrseus a wing. 
PLATE 5.



1. Gonepteryx Rhumni. Drimstone $B$.

2. Colias edusa Clomied yellow B 
REESE LIBRAPY UNIVERSITY

CALIFORNIA. 
pale in the centre. The body is black above, and clothed with fine white silky hairs; the under parts and the legs yellow. The antennæ are reddish, and the anterior part of the head and thorax are faintly tinged with rose-colour.

The caterpillar is elongated and naked, of a light green colour, with numerous black scaly dots on the back, and a pale line along each side of the belly. It is said to feed on the buckthorn (Rhamnus catharticus), and the berry-bearing alder ( $R$. frangula). It changes into a short angular chrysalis with a single conical beak, which is attached by the tail, and has a loose girth round the middle.

This insect is generally distributed over the southern parts of England : it likewise occurs pretty far to the north, as it is abundant at York, and has been observed by $\mathrm{Mr}$ Wailes on the magnesian limestone district near Newcastle, and by Mr Wilson on the banks of Winciermere. It has not, however; been noticed in scotiana, a circumstance perhaps to be attributed to the rarity of the plants from which the larvæ derive their sustenance. It very often survives the winter; and its early appearance (sometimes before the middle of February), together with the gay tint of its colour, and the graceful outline of its wings, render it one of the most interesting heralds of the "grata vice veris et Favonii." "The very first butterfly," says Mr Knapp, "that will

And sport and flutter in the fields of air, 
is the sulphur butterfy, which, in the bright sunny mornings of March, we so often see under the warm hedge, or by the side of some sheltered copse, undulating and vibrating like the petals of a primrose in the breeze." There are two broods, the first appearing in May and June, the last in autumn. It occurs in great profusion in all the continental countries of Europe, and often in company with another species so closely resembling it, that the one might readily be taken for a variety of the other. The atter is named G. Cleopatra, and presents scarcely any other distinctive mark, but a suffusion of bright orange-red on the middle of the primary wings of the male. Mr Curtis has figured, with his usual accuracy and elegance, what he regards as a variety of G. Rhamni, taken many years since in the neighbourhood of London, and possessing characters almost intermediate between the two species.

- Journal of a Naturalist, 98. 


\section{CLOUDED YELLOW BUTTERFLY.}

Colias Edusa.

PLATE V. Fig. 2.

Colias edusa, Fab._Donovan, vii. Pl. 238, Fig. 2, fema:e, and ii. Pl. 43 (C. hyale), male.-Pap. Electra, Leuin, Pl. 32.-Clouded yellow or Saffron B., Harris' Aur. C. Helice, Haworth, Jermyn, var.

In the form of the antennæ, oral organs, and most other parts from which generic characters are usually drawn, Colias presents no very important difference from the preceding genus. The wings, however, are of a different shape, the primary pair being triangular, and the secondary ones rounded. The species are not very numerous, and none of them, even of the exotic kinds, are beyond the midlle size. They are remarkable for the uniformity of their tints, the ground colour being some shade of yellow, often tinged with green, and a portion of the wings more or less marked with black. This general resemblance has led to some confusion in their synonymy. The male of C.edusa is fulvous above, or pale orangeyellow; the upper wings with a wide black border at the extremity, which is waved on its inner edge, and a rounded spot of the same colour in the middle 
of each. The hinder wings are likewise margined with black, the ground colour slightly mixed with green, and there is on each a round discoidal spot of deep yellow. On the under side, the upper wings are pale tawny on the disk, and greenish at the extremity, with a central black spot, and an obsolete series of blackish spots parallel with the outer edge: the under wings greenish, with a central silvery ocellus, having another small one adjoining, and a curved row of faint rust-coloured dots posteriorly. The body is yellowish-green, dusky on the back: the antennæ reddish. The female is distinguished chiefly by having a few yellow spots on the black marginal band of the upper wings. Examples of this sex sometimes occur, in which the parts, usually yellow, are greenishwhite, a circumstance which has led some authors to describe it as distinct, under the name of $C$. helice. Varieties of both sexes have been found in Britain, of a considerably smaller size and paler colour than ordinary specimens, and presenting at the same time so many other minute points of difference, that they have been figured and described as examples of the species named chrysotheme by continental naturalists.*

The caterpillar is deep green, with a white line along each side of the belly, marked with yellow spots and minute bluish dots. On the Continent it is found chiefly on the Cytisus austriacus, but as,

* See Stephen's Illus. of Entom. Haustellata, vol. i. p. 1], P1. II.*, figs. 1, 2. 
that plant is not indigenous to Britain, it probably feeds in this country un sulno diadelphous herb pertaining to the same natural order. The butterfy occurs in the south of England in considerable plenty in particular years, while in others scarcely an example is to be met with. It seems to prefer the vicinity of the sea, having been found more copiously than elsewhere along the south-east coast, particularly in the neighbourhood of Dover. It is likewise seen occasionally in the midland counties. Over foreign lands C. edusa is characterised by a very extensive range. It is well known in most portions of the continent of Europe. Mr Burchell found it in the south of Africa, and Mr Swainson has seen specimens from the mountains of Nepaul. 


\section{6}

\section{PALE CLOUDED YELLOW BUTTERFLY.}

$$
\text { Coline trople. }
$$

\section{PLATE VI. Fig. 1.}

Pap. Hyale, Linn. Donovan, vii. 238, Fig. 1.-Curtis, Brit. Ent. vi. 242.-Pale Clouded Yellow, Harris' Aurel.Lewin, $\mathrm{Pl} .33$.

Thrs fine species is generally somewhat larger than the preceding, the male of a fine sulphur-yellow (sometimes, however, nearly white); the female white, faintly tinged with sulphur. The upper wings are greyish at the base, marked with a black spot near the middle anteriorly, and having at the extremity a broad black border, which is attenuated at the hinder angle, and almost divided by a series of nearly continuous spots down the middle. The under wings have a large orange spot on the disk, with a small one attached to it; the margin next the upper wings is dusky, and there are a few dusky spots remote from the outer edge, and nearly parallel with it. Beneath, the upper wings are whitish.yellow, suffused with orange at the tip, having a discoidal black spot with a yellow centre, and a row of small dusky marks at some distance from the outer mar- 
PI.ATE

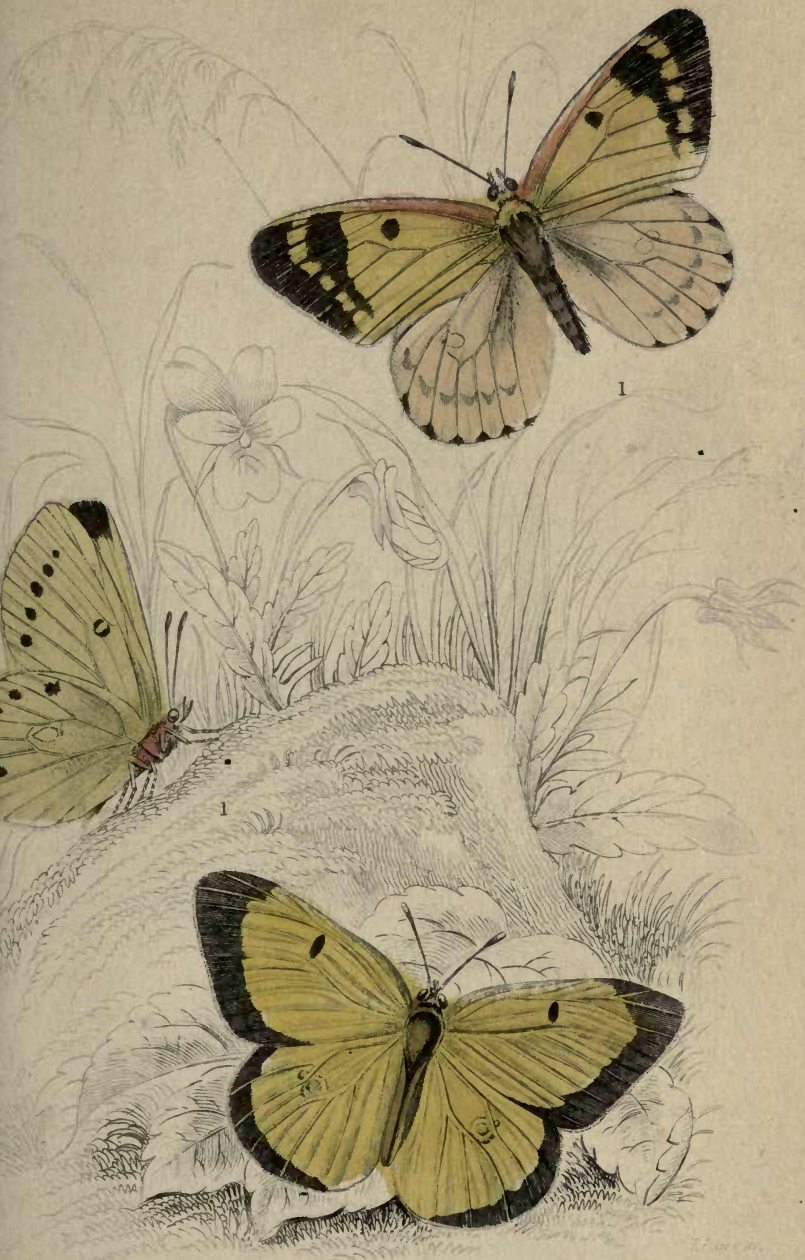

1. Colins Hyale.

Pate clouded yellow. 


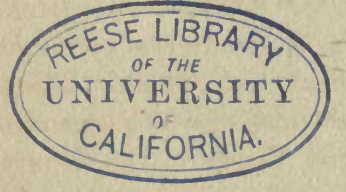

는 
gin : the under wings dull orange, with a large and small silvery spot in the centre, cinctured with rustred, and a curved row of small black spots. The fringe of the wings and the antennæ are rose-red.

The caterpillar is green, with two white lines on the sides, each segment marked with two irregular transverse series of black spots. (Plate III. fig. 2.) Its appropriate food is said to be the Coronilla varia, but in this country it must often content itself with other fare, and probably has recourse to different kinds of diadelphous plants. The butterfly is considerably rarer than C. edusa; and, like that species, is found chiefly on the sea-coast in the south-east corner of the island, as in Kent, Sussex, and Suffolk. There is a pale variety, nearly pure white, of which examples of both sexes have occurred, chiefly in the vicinity of Dover. Indeed, the insect may almost be said to be a maritime fly, so rarely has it been noticed at any distance from the sea-coast. 


\section{SCARCE CLUUDED YELLOW BUTTERFLY.}

\section{Colias Europome.}

\section{PLATE VI. Fig. 2.}

Stephen's Illus. ii. Pl. 1", Figs. 1, 2, and 3.-Eurymus Eura pome; Clouded Sulphur, Swainson's Zool. Illus. 2d ser. No. 15.-Haworth, Lep. Brit. 13. No. 12.

"Both sexes of this fine insect are of a fine sulphureous-yellow above; the male has the hinder margin of both wings deeply edged with black, an ovate spot of that colour on the disk of the anterior, and an obsolete fulvous spot on that of the posterior; the border on the latter is irregularly sinuated within: beneath the anterior wings are paler, with the tips rather deeper, the discoidal spot is whiter, with a black or dusky iris, and parallel with the hinder margin is a very obsolete row of dusky spots ; the posterior wings are of a deeper yellow, minutely irrorated with black, with a discoidal silvery ocellus, having a fulvescent iris, and a secondary silver spot adjacent ; they have also an obsolete row of dusky spots parallel with the hinder margin, and forming a continuous series with those of the anterior wings, and a larger somewhat triangular fulvescent spot on the upper edge. The female differs in having the black border of the 
hinder margin of the anterior wings, irregularly spotted with yellow, and in wanting the border to the posterior wings, having in its place some obsolete triangular dusky spots. Both sexes have the extreme edge, both above and below, and the cilia, rose-colour:"

Having never seen authentic specimens of this insect, we have introduced the description of the author by whom it was first made known to the public as British. Many doubts have been expressed as to its being strictly indigenous, and perhaps the evidence which at first led to its being regarded in that light, might not unjustly be considered somewhat inconclusive. But since the means of identifying the species became accessible to all, several announcements have been published of its having been found in England. It has been observed near Ipswich, in Suffolk, and also in Sussex. "Has been noticed in the meadows near the confluence of the Avon and Severn, flying with great swiftness, in August, but it is a rare insect." 


\section{0}

\section{Genus PONTIA.}

THIS genus comprehends the white butterfies, which are so common in gardens, and which are so well known for the depredations they commit in their caterpillar state, on cabbages and other oleraceous plants. The species are by no means numerous, but they are so prolific, that even in those seasons which are most unfavourable to the increase of insects, we seldom fail to see them flitting about in every transient gleam of sunshine. Till lately our native species were not thought to exceed three, but an indefatigable naturalist, who has laboured most successfully in elucidating the entomology of Britain, has described four others, which he regards as distinct, and which he names $P$. Chariclea, Metra, Napaea, and Bryonia. "It yet remains to be seen, however," says the Rev. W. T. Bree, "whether, in the judgment of entomologists in general, these early whites (as they are termed), will eventually maintain their place as genuine and distinct species. For myself, I may say that I have not been unobservant of these insects for some years past, and have more particularly attended to them during the spring and summer of the present year; and as far as my observations go, they lead me to the conclusion, that $P$. Chariclea and Metra are mere varieties respectively 
of P. Brassicae and Rapa. P. Rapa is avowedly a very variable insect, and being too, as well as $P$. Brassica, a most abundant species, there is consequently the more scope,-there are so many more chances - for variation to take place in the individuals. It must be admitted, indeed, that when a small and perfectly immaculate specimen of P. Metra is compared with a full sized and strongly marked one of P. Rapa, the prima facie difference is so wide, that any one would at once pronounce them distinct. But then, on the other hand, we find that intermediate specimens occur, which, presenting every possible shade and gradation of difference, appear naturally to connect and identify the two extremes; and it would be next to impossible to decide, in many instances, to which of the two these intermediate links should with more propriety be referred. The same observations apply alsu to the kindred species $\boldsymbol{P}$. $\mathrm{Napi}$, the earliest spring specimens of which are smaller than those of the summer brood, paler in their markings above, and sometimes also entirely destitute of them; and this species too, like P. Brassica and Rapoe, is subject to endless variations. No material difference has yet been observed in the caterpillar or chrysalis of the early whites, to distinguish them from P. Brassica and Rapa ; and the distinctions in the markings, \&c. pointed out by Mr Stephens in proof of their being genuine species, seem scarcely sufficient to outweigh what may be urged on the other side."*

- Loudon's Mag. of Nat. History, iii. 242. 
The judiciousness of the above observations, few who have had an opportunity of examining the insects to which they refer will, we think, hesitate to acknowledge ; and, taken in connexion with other points of agreement subsequently pointed out, they seem to leave little doubt about the propriety of regarding the reputed new species as mere varieties. Several competent observers, however, being still inclined to consider them distinct, it may be as well in the meanwhile to regard them in that light, till it be seen whether further investigations tend to confirm or confute this opinion. With the view of aiding such inquiries, we have described $P$. Chariclea, Metri, and Sabellica, and given figures of them from characteristic examples procured from the cabinet of the eminent naturalist by whom they were first named and described as likely to prove genuine species.

The true Pontia may be known by the following characters : Antennæ long and slender, terminating in a somewhat abrupt, compressed, obconic club, consisting of seven or eight joints, and grooved on one side; palpi clothed with scales, and fringed with hairs externally, the terminal joint longer than either of the preceding; anterior wings nearly three-cornered, the apical angle not very acute; the posterior wings rounded and not variegated beneath : legs alike in both sexes, the claws slightly forked. The chrysalis terminates anteriorly in a single beak, and is attached by the tail, and has a loose band round the middle. 


\section{3}

\section{COMDMON CARIBATE BITTERFL:.}

\section{Pontia Brassica}

\section{PLATE VII. FIGs. 1 AND 2.}

Pan, Brassicx, Linn.-Don. xiii. 29, 446.-Lewin, Pl. 25.Large Garden White, Harris.

IN this well known insect the wings are white above, with a large patch of black, somewhat inderited on its inner edge, on the tip of the anterior pair : the male has no other mark on the upper surface, except a black spot near the middle of the anterior edge of the secondary wings ; but the female, besides the spot just mentioned, has two others on the disk of the upper wings, and an elongated patch at their hinder margin. On the under side, both sexes are nearly alike; the colour inclines to yellow, especially on the hinder wings, which appear as if sprinkled with black, owing to an intermixture of dark-coloured scales; the upper wings bear two conspicuous black spots on each, and there is an indistinct dusky mark on the anterior margin of the hinder pair. The fringe of the wings is yellowish, slightly waved with black. The body and antennæ are white beneath 


\section{4}

and black above, the former clothed with hoary pubescence on the thorax. Males sometimes occur spotted with black on the upper wings, somewhat in a similar manner to the female.

The caterpillar is green, having a narrow ine of yellow along the back, and another on each side of the belly; the body pretty thickly covered with black tubercular points, each of them.with a hair in the centre. Besides consuming the different varieties of the common cabbage (brocoli, cauliflower, \&c.), this destructive caterpillar has been often found to attack the turnip, and its voracity is so great, that these useful vegetables would often be completely destroyed, were it not for the numerous enemies which prevent its superabundant increase. Of these, the most formidable are the parasitical ichneumons, es. pecially the minute species formerly described,* and others allied to it. The small birds likewise destroy great numbers. "I once observed a titmouse ( $\mathrm{Pa}$ rus major)," says Haworth, "take five or six large ones to its nest in a very few minutes. In inclosed gardens, sea-gulls, with their wings cut, are of infinite service. I had one eight years, which was killed by accident, that lived entirely all the while upon the insects, slugs, and worms he found in the garden. Poultry of any sort will soon clear a small piece of ground ; but unless they are of the web-footed kind they do much mischief, by scratching the earth.' But perhaps the most effectual method would be to 
COMMON CABBAGE BUTTERFLY.

destroy the parent flies when they first begin to appear in May, before they have had time to deposit their eggs.

The butterfly is first seen on the wing about the middle of Mav, but in the south of England it often appears much earlier. It occurs abundantly in all parts of Britain, and seems to be equally plentiful throughout Europe. 
EARLY WHITE CABBAGE BUTTFRFLY.

\section{Pontia Chariclea.}

PLATE VIII. Fig. 1.-MAl.E.

Stephen's Illus. Haust. i. Pl. 3, fig. 1. đ, fig. 2. ㅇ

THIs insect is in general considerably less than the preceding species; the anterior wings have a similar patch on the tip, but it is of a light brown, approaching to ash-colour, clouded with black internally, especially in the female, and having no strongly marked indentations on its inner side; the fringe yellowishwhite. On the underside, the tip of the primary wings is yellow, and the secondary pair entirely deep yellow, very thickly sprinkled with minute black points; in other respects there is no appreciable dif ference from $P$. Brassica.

Said to occur in the beginning of May, and again in the end of June. It has hitherto been observed chiefly in Hertford and Derbyshires ; and Mr. Wailes thinks that he has seen it in the neighbourhood oNewcastle. 




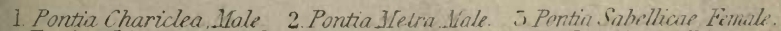
Early White Cabhage B. Howards White. Mhushy veimed thite. 
REESE LIBRAAY

UNIVERSITY

CALIFORNIA.

늘 


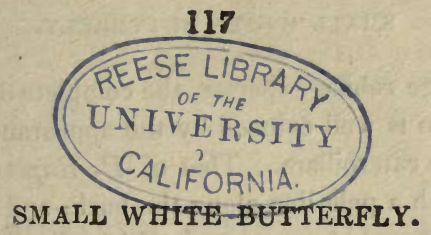

\section{Pontia Rapa.}

\section{PLATE VII. Fig. 3.}

Pap. Rapæ, Iinn.-Lewin, Pl. 26.-Pap. alba mediẹ, Raii, Hist. Insect._Small Garden White, Harris.

THe expansion of the wings is from one inch and eight lines to two inches five lines; it is therefore considerably smaller than the preceding, to which in other respects it bears a strong resemblance. The upper surface is white, slightly inclining to yellow; the primary wings have a dusky spot at the tip, extending a short way along the anterior border ; in the male there is a single rounded spot on the disk, and two in the female, with an oblong patch behind, as in the same sex of $P$. Brassica; the hinder wings with the usual black mark on their anterior border. Beneath, the anterior wings bear two discoidal black spots, the tip is yellow, and the base slightly sprinkled with dusky; the under wings are rather bright yellow, with dark scales intermixed, making them appear as if powdered with black dust ; on the anterior edge at the base, there is a narrow streak of orangeyellow.

Although this butterfly bears so much resemblance 
to the large cabbage species, the complete distinction of the two is well evinced by the appearance of the respective caterpillars. That of $P$. Rape is lightgreen, with a pale line along the back, and a whitish streak, somewhat punctured with yellow, on each side of the belly. It feeds on cabbages, turnips, \&c. and is often found associated with the larva of $P$. Brassica in devastating our garden produce. It generally insinuates itself between the folded leaves in the centre of cabbage and cauliflower plants; hence it is named in France ver du coeur. The butterfly is very common in all parts of this country, and in most quarters of Europe. Il appears in the end of April or beginnıng of May, and a second flight takes place in July. But the insect is at all times so abundant, that there is probably a succession of broods throughout the summer and autumn. The markings vary considerably. 


\section{9}

HOWARD'S WHITE BUTTEKFLY.

Pontia Metra.

PI,ATE VIII. Fig. 2.

Stephen's Illus. Haust. i. 19.

THE wings of this insect expand from 20 to 25 lines. The colour is entirely yellowish-white, the base of the wings blackish, and the tip of the anterior pair, which is more acute than in the allied species, slightly suffused with light brown: in the male there is a single dusky spot, and in the female two, which, however, are always very obsolete, and sometimes, as in the variety figured, entirely wanting. The hinder wings are wholly white, with the usual dusky spot anteriorly. The tip of the upper wings is yellow beneath, and two faint spots are observable on the disk; the hinder wings beneath rather bright yellow, especially on the anterior edge at the base, and sprinkled with black points. The fringe of the wings is nearly pure white.

Occurs early in April, and there appears to be a second brood in June. It has been noticed chiefly in the south of England, but is probably to be found 

HOWARD'S WHITE BUTTERFLY.

in most parts of the country. "Found near Newcastle early in spring, but whether specifically distirirt I have been unable to satisfy myself: thus much I may say, I never took it in the autumn."G. Wailes, Esa. 
GREEN-VEINED WHITE BUTTERFLY.

Pontia Napi.

PLATE IX. Fig. I.

Pap.Napi, Linn._Lewin, pl. 27.-Donovan, viii. 23. pl. 280. fig. 1.-Green-veined white, Harris.

THE wings of this species expand from 17 to 22 lines; the colour white, inclining to yellow. The tip of the primary wings is dusky, and in the male there is a round black spot near the middle, not very remote from the outer margin, the female having two such spots on each wing. The hinder wings are free from marks, except the ordinary dusky spot on the anterior margin. On the under side, the tip of the primary wings, and the whole of the secondary pair, are sulphur-yellow, the nervures strongly marked with a dilated line of dusky green; and there are two black spots on the upper wings, near the hinder margin. The body and antennæ are nearly as in the preceding species.

The caterpillar feeds on tetradynamous plants, particularly those belonging to the genus Brassica. It is of a dull green colour, lighter on the sides, with 
yellow stigmata, and covered with white warts, which are blackish at the tip, and tufted with short hairs. The chrysalis is greenish-yellow, the angles very acute and prominent.

This butterfly is one of the most common species both in this country and throughout Europe. Its first time of appearance is about the middle of May, and it is again abundant in the beginning of July. It presents numerous variations in its size and markings, of which it is unnecessary to give a particular account. One of the most remarkable has been regarded as a species by Esper and others, and described under the name of Napace. It is of larger size than ordinary specimens of $P$. Napi, the upper wings with a black spot, the tip and some triangular patches being of the same colour: the secondary wings rather pale, and having only the three first nervures dilated and greenish. This variety seems to occur not unfrequently. 


\section{DUSKY-VEINED WHITE BUTY'ERFLY.}

\section{Pontia Sabellica.}

\section{PLATE VIII. FIG. 3.}

Stephens, Illust. Haust. i. pl. 111 * fig. 3 ठే ; fig. 4 ๆ.-Pap. Bryoniæ, Godart, Ency. Meth. No. 146.

UPPER surface of the wings, which are short and considerably rounded, yellowish-white; the base, anterior margin, and the tip, dusky black, all the nervures with a broad stripe of the same colour, the male having a single dusky spot towards the tip, and the female twn. On the under side, the hinder wings, and the tip of the antelior pair, are tinged with sulphur-yellow, and all the nervures are broadly margined with dusky.

The larva of this insect, which may eventually prove to be a distinct species, is not known. The fly has been frequently taken in the vicinity of London. "Not rare in some seasons near Newcastle." -G. Wailes, Esq. 


\section{Genus MANCIPIUM.}

So close a connexion subsists between this and the preceding genus, that the species have been generally grouped together under a common generic name. But the structural differences of M. Cardamines and Daplidice are too considerable to admit of their being associated with the true Pontia, however much they may be allied in habit and general appearance. The principal distinctions consist in the relative proportion of the joints of the palpi, which, in Mancipium, have the terminal joint shorter than either of the two others; in the rounded form of the tip of the anterior wings; and in having the under side of the secondary pair variegated - characters sufficient to constitute a subgenus. The chrysalis (at least in M. Cardamines), is boat-shapea. heing widest in the middle, and narrowing gradually to hoth ends. 


\section{BATH WHITE BUTTERFLY.}

\section{Mancipium Daplidice.}

PLATE IX. Fig. 2.

Pap. Daplidice, Linn.-Lewin, pl. 28.-Donov. vi. 47, pl. 200. - Bath White, Lewin, 1. c.-Green chequered White, Haworth, Curtis, B. E. i. pl. 48.

THE male of this rare British insect is nearly white above; the superior wings have a large blackish patch at the tip, interrupted by large spots of white, and a dusky spot near the middle, with a faint white streak across the centre of it. The secondary wings are unspotted in this sex, but in the female they are widely bordered with black, which is sinuated and divided by large spots of the groundcolour of the surface: the female has likewise an additional black spot on the upper wings, near the hinder angle, and is usually larger than the male. The markings on the under side of the primary wings nearly correspond to those on the upper side, but instead of being black, they are greenish. The hinder wings are green beneath, sprinkled with minute black points, with a row of large white spots on the hinder margin, an irregular cross band of white, and three spots of that colour towards 
the base. The antennæ are whitish, variegated with black.

The caterpillar frequents the different species of Brassica; also wild Mignonette (Reseda lutea), Thlaspi arvense, and other cruciferous plants. It is of a dull biue, according to Godart's description, bordered with yellow, and covered with black points; the head clear green, with yellow spots and black points. The chrysalis is at first greenish, but afterwards becomes grey.

Although recorded from a remote period as a native of Britain, this insect still continues to be classed among our rarest kinds. It is noticed by Ray as having been found near Cambridge: it has likewise occurred at Hampstead in Middlesex, and in the neighbourhood of Bristol. More recently it has been taken, both by $\mathrm{Mr}$ Stephens and $\mathrm{Mr}$ Le Plastrier of Ramsgate, in the meadow under Dover Castle, in the month of August. We are told by Lewin, that it was named the Bath White, from a piece of needlework, executed at Bath by a young lady, from a specimen of this insect. said to be taken near that place. 




ORANGE-TIP BUTTERFLY.

Pontia Cardamines.

PLATE X. Figs. 1. \& 2.

Pap. Cardamines, Linn._Donovan, v. pl. 169._Levein, pl. 30._Orange-tip, or Lady of the Woods, Harris, Aurel. pl. 32. -Pontia Cardamines, Steph. Illus.-Mancipium Cardamines, Hubner.

THIS delicate and warmly tinted species seems to occur in considerable plenty in all parts of Britain, and it is not unfrequent in Ireland. Its ordinary time of appearance is near the end of May, but when the weather is mild it is on the wing much sooner, especially in the southern parts of England, where it has been sometimes seen by the middle of A pril. It frequents lanes and open glades in woods, and sometimes enlivens our gardens by its gay and fitful flight. The sexes are so dissimilar, that they were mistaken by Ray and some other authors for distinct species. The expansion of the wings varies from an inch and a quarter to nearly two inches. The primary wings are white, dusky at the base, with a small black crescent-shaped spot in the middle, and an interrupted patch of black round the tip : the 
outer half of the wing is deeply tinged with orange in the male, but there is no trace of that colour in the female. The hinder wings are alike in both sexes; on the upper side they are dusky at the base, the outer margin bears a few blackish points, and the surface presents faint traces of the markings on the under side; the latter consist of irregular marmorated spots of green, powdered as it were with yellow. The antennæ are white, with dark rings.

The caterpillar feeds on several cruciferous plants, especially those of the genus Cardamines; also on Turritis glabra, Brassica campestris, \&c. It is of a green colour, with a whitish line along each side, just above the insertion of the legs. The chrysalis is also greenish-yellow.

\section{WOOD WHITE BUTTERFLY.}

Leucophasia Sinapis.

PLATE X. Fig. 3.

Pap. Sinapis, Linn.-Donovan, vii. pl. 280_-Pontia Sinepis, Leach, Jermyn.-Wood White, Harris' Aur. pl. 29. -Leucophasia Sinapis, Steph._Leucoph. Loti, Rennie.

THE present genus (named from $\lambda$ svxos, white, and Qarbs, an apparition or appearance), is distinguished by the structure of the palpi, which are 
short and flat, with the basal joint large and conical, the second short and quadrate, and the third or terminal one minute, and almost globular; and by the shape of the wings, which are very narrow, and almost elongate-oval, the surface wholly covered with scales. The antennæ have an abrupt compressed club, and the legs, which are alike in both sexes, terminate in bifid claws.

It is much the smallest of our white Butterflies, and the narrow elongated wings give it, as has been well remarked, something of the appearance of a Dragon-fly. The colour is nearly milk-white, the base of all the wings somewhat dusky, and the tip of the anterior pair with a large brown spot. On the under side the latter are faintly tinged with green at the tip, and the costa is sprinkled with black points from the middle to the base. The under side of the hinder wings is tinged with yellowis!green, and sprinkled with ashy points, which form indistinct clonds and bands.

The caterpillar is usually found on the Bird's-foot Trefoil (Lotus corniculatus), and Meadow Vetchling (Lathyrus pratensis). It is green, with a deep yellow line along each side of the body.

There are two broods of the butterfly each season, one in May, the other in the end of July. Although an abundant species in most parts of Europe, it is rather scarce in Britain. In certain localities, however, it has been found in plenty; - as in Darenth 
wood, Hartley and Bromley woods, Essex ; also ir Surrey, Kent, Devonshire, \&c. We have not heard of its occurrence in Scotland. It has been taken by $\mathrm{Mr}$ Heysham near Carlisle, the most northern locality hitherto ascertained. 


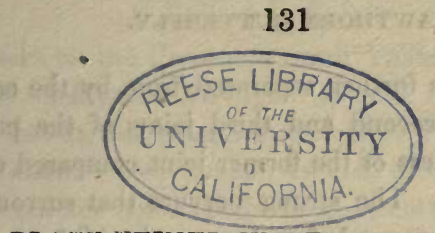

BLACK-VEINED WHITE, OR HAWTHORN BUTTERFLY.

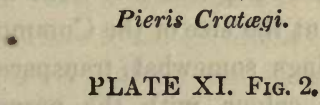

Pap. Cratægi, Linn.-Lewin, pl. 24.-Donovan, xiii. pi. 451.-Hawthorn Butterfly, Kirby \& Spence.

IN this genus the antennæ are rather slender, and the club is formed gradually: the palpi have the two lowest joints robust, the radical one being twice the length of the second, while the terminal one is about the length of the second, and very slender: the upper wings are nearly diaphanous, being sparingly clothed with scales; the claws are strong and bifid, and have a slender appendage on the outside at the base.

"The black-veined white is one of the few butterflies that cannot be mistaken for any other species, and it is remarkable for having both sides very similar, which is scarcely the case in any of the other British Papilionida. In this respect, as well as in the semitransparent wings and short cilia, it approaches Doritis (Parnassius, pl. 11, fig. 1.) The same characters will distinguish it at once from $P$ un- 
tia, which it is further separated from by the equal length of the second and third joints of the palpi, and the shortness of the former joint compared with the basal one. The strong nervure that surrounds each wing has never before been noticed." *

The English name sufficiently describes this spe cies, and readily distinguishes it from all its associates. It is about the size of the Common Cabbage Butterfly, the wings somewhat transparent, and of a uniform white colour, with the nervures black. There is also a black line round the outer edge of the wings, and generally a few dusky triangular marks on the outer margin of the upper pair. The caterpillars are black for some time after they are hatched, but soon become partially clothed with hairs, and striped with reddish-brown on each side of the body. (Fig. 3, PI. III. represents a fullgrown caterpillar of this species.) They are gregarious, and live for a time under a net-work of silk, which they spin for their protection. Their favourite food is the leaves of the Hawthorn, but they likewise attack fruit-trees, and have been known to commit considerable damage in orchards. This butterfly is by no means generally distributed through England, and is wholly unknown in Scotland; but it has occurred plentifully in the following places, and is occasionally observed elsewhere:- New Fo. rest, Hampshire, Chelsea, Coombewood, Enborne, Berkshire, Dorsetshire. It is by no means a scarce

- Curtis, British Ent. viii. 360. 
insect on the Continent; and Pailas relates that he saw such extensive flights of them in the vicinity of Winof ka, that he at first conceived them to be flakes of snow. The female, indeed, is very prolific, and covers her eggs, which she deposits on the extremity of a hawthorn branch, with a coating of varnish, so effectually weather-proof, that they remain in security (sometimes, it is said, for several years), till circumstances favour the exclusion of the larvæ. The chrysalis is very obtuse anteriorly, and of a yellow colour, streaked and spotter with black. (PI. III. fig. 4.) 
APOLLO BUTTERFLY.

Parnassius Apolio.

PLATE XI. FIG. 1.

Pap. A pollo, Linn.-Haworth.-Donovan, xiii. pl. 433.-

Crimson-ringed Butterfly, Haworth.-Doritis Apollo, Fab.-Steph.

IN this genus the antennæ are rather short, with the club narrow, nearly oval, and not compressed ; palpi rather long, and rising considerably beyond the head; wings nearly free from scales, especially at the apex, where they are transparent, the hinder pair concave on their inner edge. The females are provided with a small corneous bag, at the hinder extremity of the abdomen. The caterpillars have the power of protruding a retractile tentaculum from the neck, similar to that found in the larvæ of the genus Papilio, formerly described; but, unlike the latter, they form a kind of cocoon when about to change into chrysalides, by conneeting a few leaves together by means of silken threads.

The expansion of the wings is nearly three inches; the colour white, slightly tinged with yellow, each 


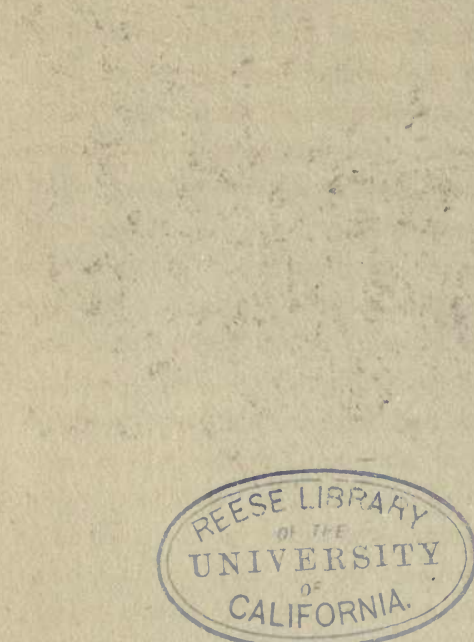

tan

ot the upper wings bearing five pretty large black spots, and each of the hinder ones two large round crimson spots, with a white pupil, surrounded externally by a black circle. The extremity of the wings is naked and transparent, appearing as if varnished, pretty thickly sprinkled with minute black dots, which form a faint flexuose cross band at some distance from the margin, and parallel with it. The base and anterior edge of the primary wings are covered with black dots; the abdominal margin of the hinder pair with similar points and long whitish hairs, as far as the extremity of the abdomen, beyond which there is a curved patch of black. The markings on the under side nearly correspond to those just described: some of the black spots on the upper wings, however, have occasionally a red mark in the centre; and on the hinder pair there are four red spots, bordered with black, forming a kind of cross-band near the base, while the anal black patch often has a red streak in the middle. The body is black, with whitish hairs on the abdomen, and reddish ones on the front of the thorax : the antennæ white, with a black knob.

The caterpillar is of a beautiful velvet-black colour, with two rows of deep orange spots on each side, one near the back, the other towards the belly: the incisures are glossed with blue, and the whole body is clothed with short black hairs. It feeds on the Orpine (Sedum telephium), and various kinds of Saxifrage, particularly Saxifraga pyramidalis. 
This insect was first introduced into our Britisb lists, in consequence of it having been supposed, through some mistake, that a few continental specimens in the possession of Lord Seaforth, were procured from the Island of Lewis, one of the Hebrides. Since that time, it has been oftener than once figured and deseribed as a British species; but no authentic instance is on record of its having been observed by any one-a circumstance which may fairly be assumed, in the case of such a marked and conspicuous object, as a sufficient indication that it is not an inhabitant of this island. We have been assured, however, that it was noticed on the wing last summer in some part of the west coast; and, though inclined to think that this must be a mistake, we willingly avail ourselves of the excuse which it affords for retaining, in the mean while, such an ornamental insect among our indigenous species. On the Continent, it inhabits the Alps, Cerennes, the mountains of Auvergne, and various parts of Norway and Sweden, in considerable numbers. Its flight is said to be slow and heary. 




1. Nemeubius Luina. 2. Melitaea Athatia Duhe of Burgundy Fritillary. Pearl borderal liheness: 
REESE LIBRARY

UNIVERSITY CALIFORNIA. 
DUKE OF BURGUNDY FRITILLARY.

\section{Nemeubius Lucina.}

PLATE. XII. Frg. 1.

Pap. Lucina, Linn.-Lewin, pl. 15.-Donovan, viii. 70. pl. 242. f. 2.-Duke of Burgundy Fritillary, Harris.Hamearis Lucina, Hübner.-Curtis, B. E. vii. 316.-Nemeobius Lucina, Stephens.-Horsf.

THIs and several of the following genera may be readily distinguished from any of the preceding, by having the anterior legs more or less imperfect, being very short, and destitute of tarsal joints, by which they are rendered unfit for walking. In the present iitstance, this imperfection is found only in the male, the fore-leg of the female presenting the ordinary structure. Nemeobius (from vqpos, a grove, and $\beta$ los, life), is further characterised by having the club of the antennæ rather large and abruptly formed; palpi very short and horizontal, the second joint much the longest, and the third, or terminal one, minute and oval. The anterior wings are nearly trigonate, and the inferior rounded; the posterior tibiæ without spurs, and the claws simple. The species above referred to, is the only one known to inhabit Britain. The expansion of the wings seldom much exceeds four- 
teen or fifteen lines. The surface is dark brown, the upper wings with three transverse series of irregular spots of light yellow or straw colour, the outer or marginal row having a black mark in the centre of each spot: the hinder wings have likewise an irregular transverse series of yellow spots, and the margin is similar to that of the other pair. The under side is much paler than the upper, approaching sometimes to orange, the superior wings with several light spots on the disk, interspersed with black streaks, and a series of light spots along the margin, with a small dusky mark in the centre of each; besides having the margin similar, the hinder wings have two pale bands, composed of continuous oval spots, the outer one edged internally with black. The antennæ are white, marked with black above, the club black, tipped with orange.

According to Hübner, the caterpillar is long, oval, and depressed, resembling those of the Lycance, which, from their resemblance to wood-lice (Onisci), are named onisciform. It is of a pale olive-brown colour, with a large black dot on each segment, and the head and legs rusty-red. It feeds on the Cowslip and Primrose. The butterfly appears to be somewhat-local, but it occurs not unfrequently. Coombe and Darenth woods have occasionally afforded it in abundance, and it has been found in most of the south -eastern counties of England. We have not heard of its occurrence to the north of Carlisle, in the neighbourhood of which it has been taken by Mr Heysham. 


\section{GENUs MFIITAA.}

Тн $\mathbf{E}$ genus Melitca, which approximates pretty closely to the following one in its characters, has antennæ with a very abrupt knob, which is large and flattish; palpi long and projecting, rather slender in some of the species, with the terminal joint ending in a point, and nearly half the length of the second; somewhat thickened in others, with the terminal joint ovate and minute; wings of moderate size, the anterior pair elongate-triangular, and the anterior legs spurious in both sexes, the claws in the other legs being either double, or simple, with a short cushion. The majority are without silver spots beneath, M. Silene and Euphrosyne being the only kinds possessing that ornament. The caterpillars are generally spinose, and the chrysalides are suspended ly the taii 


\title{
PEARL-BORDERED LIKENESS,
}

\author{
Inelutua Atnaua.
}

PLATE XII. Fig. 2.

Pap. Athalia, Esper.-Pap. Dietynna, Lewin, pl. 14. fig. 5. and 6.-Pearl-bordered Likeness, Harris-_Melitæa Athalia, Stephens.

THE expansion of the wings is from sixteen lines to two inches : the colour tawny orange, marked with black, the latter running in several undulating lines across the surface, the base blackish. Beneath, the anterior wings are pale brownish-yellow, with a few transverse streaks of black; the posterior pair with several pale angular spots near the base, edged with black; behind this there is a continuous curved band of large pale spots, also edged with black; and near the margin two series of black crescents. The fringe is yellowish-white, spotted with black.

The caterpillar is black and spiny, with two rows of small white dots on each segment, and tubercles of a similar colour on the sides. It feeds on the narrow and broad leaved plantain, and also, according to Wilkes, on the common heath. The butterHy is not uncominon in Devonshire, and many other 
parts of the south of England; but it appears to be very rare in the north. It presents several varieties, of which the most remarkable is that named $P . P y$ ronia by Hübner, represented on our 13th Plate, fig. 1. It has the upper wings blackish at the base, with a few yellow spots, the rest of the surface, as far as the black border, likewise yellow, the nervures alone being black. The hinder wings are entirely dark brown, with a row of small yellow spots towards the margin, and a few others in the male near the base. The under side of the upper wings is yellow at the base, with large spots of black, the middle also black, and the extremity yellow; of the hinder pair, black at the base, with yellow spots, and a broad central baid of white intersected by black veins. This beautiful variety has heen found near Londat. 


\section{GREASY FRITILLARY.}

Melitea Artemis.

\section{PLATE XIII. FIG. 2.}

Pap. Artemis, Fabr._Lewin, pl. 15._Pap. maturna, Esper. Greasy Fritillary, Harris,-Melitæa Artemis, Stephens Illus. Haust. i. p. 32.

THE ground-colour of the surface is deep brownish-yellow, the primary wings with black transverse undulating lines, and light yellow spots : the secondary pair with three bands, the intermediate one tawny orange, with six small black spots, the others irregular, and of a light yellow. Beneath, the primary wings are somewhat glossy, paler than above, but the markings nearly similar; the hinder pair fulvous, having three bands of pale yellowish spots, edged with black, that next the base very irregular, the central one curved, and the other consisting of semicircular spots placed along the margin; between the central and marginal band, the row of spots formerly mentioned is distinctly marked, and each is surrounded with light ochre-yellow. The fringe of the wings is yellow, interrupted with black on the 
PLATE 13 .

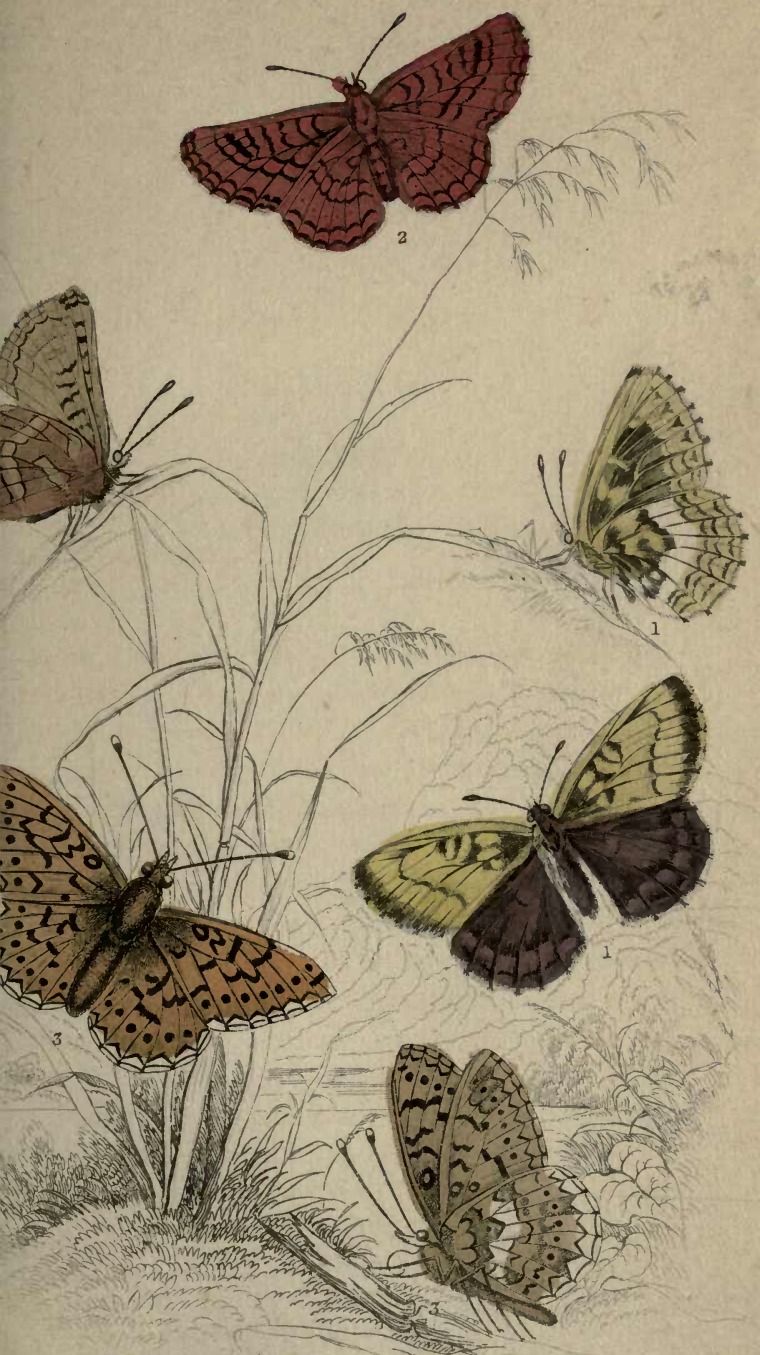

1. Nelituea Athatua, var:

2. Mrlituea Artemis, Greasy Firtiluary

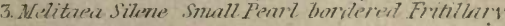


anterior wings only. The other parts are nearly as in the allied species.

The caterpillar feeds on the two common species of Plantain, and also on the Devil's-bit Scabious. The body is black above, armed with spines of the same colour, and the under side is yellow. A line of very minute white dots is drawn along the back, and another on each side. The legs are reddish. The butterfly first appears on the wing towards the middle of May, and, like most of the Fritillaries, it presents a considerable number of varieties. It owes its English name to the glistening appearance of the wings, especially on the under side, which look as if they had been rubbed over with grease. It appears to occur in most of the southern counties of Eng. land, and is said to be particularly abundant near Brighton, and at Enborne in Berks. It likewise occurs pretty far to the north, as we are informed by $\mathrm{Mr}$ Andrews that it has been found near Durham; and P. J. Selby, Esq. has taken it near Belford, in the county of Northumberland. 


\section{GLANVILLE FRITILLARY.}

Melitea C'inxia.

\section{PLATE XIV. FIG. 2.}

Pap. cinxia, Linn.-Lewin, pl. 14.-Haworth, 36.-Glanville Fritillary, Harris.-Melitæa cinxia, Steph.

BEARS considerable resemblance to the preceding species, but is usually larger, and the markings are dissimilar. The colour is orange-tawny above, and the whole surface is reticulated and spotted with black, the posterior wings having a series of five or six black spots, forming a row parallel with the hincler margin, and at some distance from it. Beneath, the colour is much paler than above, the primary wings with a few transverse black streaks, and a series of black crescents towards the tip; the hinder pair with three irregular bands of pale spots, edged with black, and a row of black spots, with an ochreous iris. The fringe is whitish-yellow, spotted with black.

The caterpillars are black, with rows of white dots on the incisures, and along the sides; the head and prolegs rust-red. They feed on the Narrowleaved Plantain (Plantago lanceolata), Mouse-ear Hawk-weed, and the Common Germander Speed- 
well (Veronica chamadrys). They generally issue from the egg towards the end of the autumn, and pass the winter before they undergo their final metamorphosis. To protect themselves against the rigour of that season, they assemble in little colonies, and form a kind of tent, by drawing together a few of the leaves of the plant on which they feed, and covering the whole with a web of silk. The butterfly appears in June, but in this country it is by no means of frequent occurrence. It has been found, however, rather plentifully in the Island of Wight, also near Dover, and in a few other places in the southern parts of England. It is abundant on the Continent.

\section{PEARI -BORDERED FRITILLARY.}

\section{Melitea Euphrosyne.}

PLATE XV. Fig. 2.

\section{Pap. Euphrosyne, Linn.-Lenvin, pl. 13.-Donovan, xi. pl. 312.}

THE expansion of the wings varies from 18 to 22 lines. All the wings are of a reddish-yellow coour above, blackish near the base, and variegated with transverse streaks or spots of black; each of them having a row of black spots towards the apex, and a band of the same colour along the outer mar 
gin, which forms on the inner side a trangular point in the centre of each areolet, and encloses a "ow of pretty large round spots, corresponding to the ground colour of the surface. The primary wings are rather bright yellow beneath, the black spots smaller than the corresponding ones on the surface, and the tip spotted with light yellow. The hinder wings bear several large yellowish.white spots at the base, some of them slightly glossed with silver, the spaces between being rust-red; the latter colour forms a large spot in the middle, ornamented with a central ocellus. Beyond this, there is a long quadrate silvery spot, forming part of a very irregular band of yellowish.white; the space between which and the hinder margin is variegated with rust-brown and yellow, and a row of dark spots. The hinder margin is adorned with a row of large triangular silvery spots, bounded on all sides by a deep black line, The fringe of the wings is yellowish, spotted with brown; the antennæ ringed with white, and the knoh tipped with reddish-brown. Several varieties occur, of which the most remarkable are those having only one silvery spot on the disk of the inferior wings; and such as have the basal half of the upper wings black, spotted with yellow, and their under side marked with large black spots.

The caterpillar is black and spinose, with macular lines of orange along the back. It feeds on different kinds of Violet, particularly the Dog's Violet. and Viola lutea. The butterfly is apparently dis- 
tributed over the whole island, as we have seen nom tices of its occurrence in most parts of England; and numerous specimens have been received from Perthshire, Ross-shire, Sutherland, and others of the more northern counties of Scotland, while it is not rare inrougnout the lowlands. It is a double-brooded species, frst appearing in the end of May, and again in autumn. 
SMALL PEARL.BOKDERED FRITLILARY.

Melitca Silene.

PLATE XIII. F'tu. 3ิ.

Pap. Silene, Fabr. Haworth. - Melitæa Silene, Jermyn, Steph._Pap. Euphrasia, Lewin, pl. 13._Small pearl-bordered Fritillary, Haworth.

RATHER smaller than the preceding, which it greatly resembles on the surface : the characters by which it is distinguished on the under side, consist in the ground colour of the secondary wings being ferruginous, or rust-brown, with the transverse band at the base and middle not of so light a yellow as in M. Euphrosyne: in having three silvery spots in the central band, and five others, three of which are placed in a line on the anterior border, and the other two near the inner edge; in having only six triangular spots of silver on the border; and, lastly, in having the ocular spot towards the base black, with a red pupil.

The caterpillar is described as being black and spiny, the one-half of the spines yellow, and the sides of the body marked with a light-coloured stripe. The butterfly is of frequent occurrence, but seems 
SMALL PEARL-BORDFRED FRITILLARY. 149

to be less generally distributed than the preceding. In Scotland it is much scarcer than M. Euphrosyne. " Not at all rare near Newcastle, appearing in the beginning of July, while $M$. Euphrosyne usually appears in the beginning of June."-G. Wailes, Esq. "Both these species are abundant near Durham." -G. Andrews, Esq. 


\section{GeNrjs ARGYNNIS.}

Although constituted by a very limited number of species, this genus ranks among the most important we possess, as comprehending a few of the largest and most richly ornamented of our native butterflies. When viewed from above, however, there is no appearance of much embellishment, the surface being rather remarkable for uniformity of tint, consisting of some shade of reddish-brown, streaked and chequered with black; a mode of colouring which has probably caused the old name of Fritillary to be applied to them, from their bearing some resemblance to the tessellated markings of that flower. But the under side is decorated with.large spots and streaks of beautiful silver white, which renders them very conspicuous objects, even when contrasted with species most richly coloured in other respects, but destitute of this metallic brilliancy. They are the only British insects of their kind that exhibit this " silvery glitterance," besides the two last species of the preceding genus. To the latter, indeed, they approximate very closely in other particulars, but may be distinguished from them, as well as from other cognate genera, by the following characters:-Antennæ rather long and slender, with a very abrupt, spoon- 
shaped club, ridged on the under side: palpi with the middle joint very long, the basal and terminal joints short, the latter very slender, acicular: wings very ample, slightly scolloped, the hinder pair generally extending beyond the abdomen : anterior lege imperfect in both sexes; the four posterior legs with claws and two appendages at the base. The chrysalis is suspended bv the tail. 


\section{QUEEN OF SPAIN FRITILLAKY.}

\section{Argynurs Eaihohra.}

PLATE XVI. Fig. 2.

Pap. Lathonia, Linn.-Lewin, pl. 12.-Donovan, iii. pl. 73. -Queen of Spain F ritillary, Harris.

THE surface is yellowish-brown, with numerous insulated black spots, most of them of a rounded form. Beneath, the ground colour of the primary wings is paler than above, but they are marked with black in a similar manner, and have a few silvery spots towards the tip. The under side of the secondary wings is ornamented with upwards of twenty silvery spots, very unequal in size, seven of them of a semicircular shape, forming a row near the hinder margin, before which there is a transverse series of ocellated spots of a brownish colour with a silver pupil. The fringe is pale yellow, interrupted with black. The caterpillar, according to Godart's account, is greyish-brown, spinose, with a white line along the back. It is solitary, and feeds on the Heart's ease (Viola tricolor), a kind of Saintfoin (Hedysarum onobrychis), and Anchusa officinalis. 
PI,ATE IG

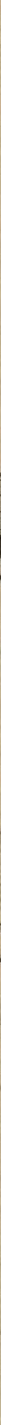


Although abundant in all the iniddle and southern countries of Europe, this butterfly is among the rarest inhabiting Britain. It is sometimes not seen for many successive seasons, while in others specimens have been procured in several places. This was the case particularly in 1818 , a year which appears to have been especially favourable to the increase of many species, which in ordinary seasons are seldom to be met with. The following localities may be mentioned :-Gamlingay and Wisbeach, Cambridgeshire; Castle-meadow, Dover ; Halvergate, Norfolk; Stoke near Nayland, Suffolk; Birchwood, Kent.

\section{HIGH BROWN FRITILLARY.}

Argynnis Adippe.

PLATE XVI. Fig. 1.

Pap. Adippe, Linn.-Lewin, pl. 10._Donovan, xiii. pl. 448. -High Brown Fritillary, Harris.

THE wings generally expand about two inches and a half, and are of a bright yellow, inclining to brown on the upper surface, with transverse undulating streaks, and round spots of black, together with a series of black crescents near the outer margin, which is itself black. On the under side, the primary wings are of a lighter hue, without the black external border, and having a few silvery spots near 
the tip ; the secondary pair are brownish-yellow, with ahout twenty-four silvery spots, six or seven of them placed irregularly near the base, the others forming two transverse bands, one near the centre, somewhat interrupted in the middle, the other lying along the outer margin, and composed of triangular spots edged internally with rust-red ; between the central and external band there is a series of small round rustybrown spots, most of them having a silver pupil. The body is blackish above, with reddish hairs, and pale yellow beneath ; the antennæ brownish, with the extremity of the club brownish-yellow.

The caterpillar is reddish, becoming olive-green with age, having a white dorsal line and white dots on the sides. It feeds on the pansy and sweet smelling violet (Viola odorata).

Not so plentiful as either of the following species, but found occasionally in many places in the southern parts of England. It is observed on the wing in the end of June and in July, and generally frequents heaths and the borders of woods. Many varieties have been described, some of them having the upper wings almost wholly black. 
PIATF 15.
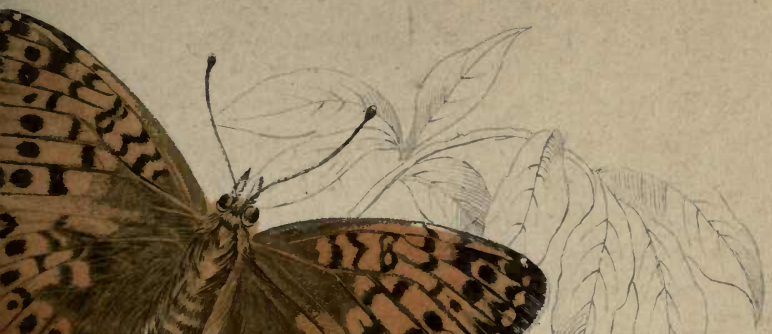

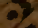


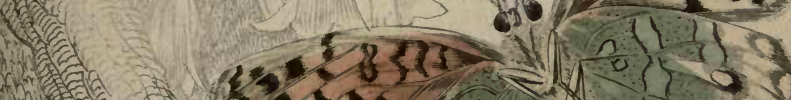

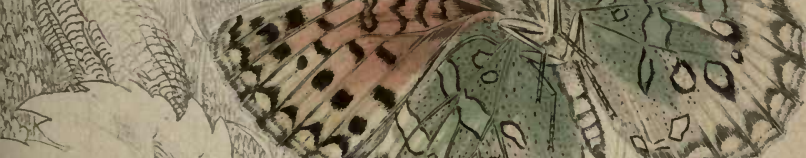
迹

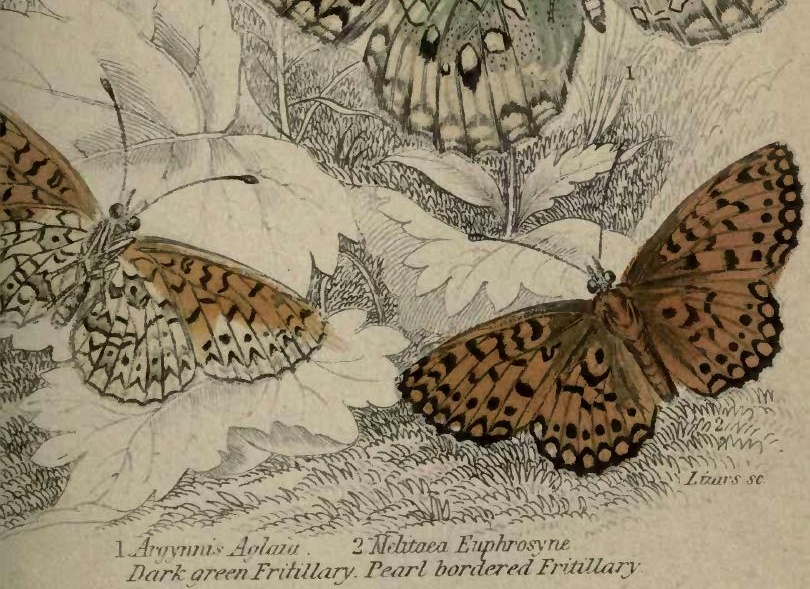




\section{CALIFORNIA.}

솔

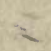




\section{5}

\section{DARK GREEN FRITILLARY.}

\section{Argynnis Aglaia.}

PLATE XV. Fig. 1.

Pan. Aglaia, Linn._Lewin, pl. 11.-Donovan, ix. pl. 302. -Dark Green Fritillary, Harris.

VERY like the preceding on the upper side, but usually rather paler, the individual figured being a dark coloured example of the female. The principal marks of distinction are to be found on the under side of the wings, which are of a fine yellowish-green, especially the hinder pair; the anterior with several silver spots on the hinder margin; the posterior with six or seven scattered silvery spots near the base, a curved band near the middle, and another consisting of seven spots of equal size parallel with the hinder margin, without any intervening row of ocellated spots. The anterior margin of the costal areolet, a portion of the abdominal one, and that lying next to it, are also glossed with silver.

The caterpillar feeds on the dog's violet. It is brownish-black, yellowish on the back, and having a row of quadrate red spots along the sides, one on each segment, excepting the two next the head. 
The chrysalis is reddish, with waved streaks of brown.

This is rather a plentiful species in most parts of the country. It is said to be abundant throughout the south of England, and we have often procured specimens from the middle and northern districts of Scotland. It is rather rare, however, in the neighbourhood of Newcastle; but occurs abundantly near Durham, in the beginning of July. It has been occasionally observed in the vicinity of Edinburgh, but it must be regarded as somewhat scarce in that neighboushood, as well as throughout the south of Scotland. 


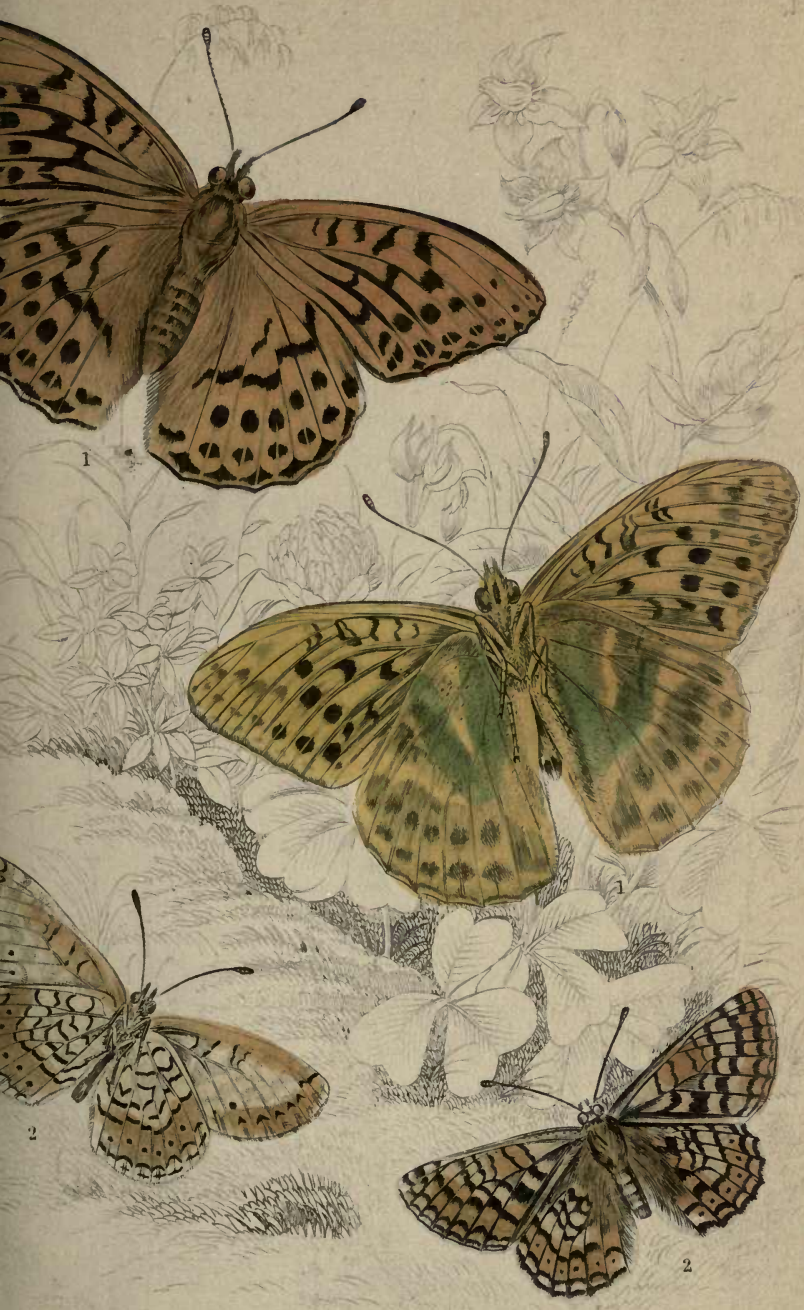


REESE LIBRARY

UNIVERSITY

CALIFORNIA. 


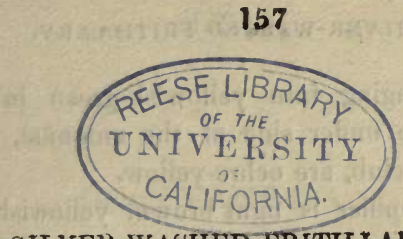

SILVER-WASHED FRITILLARY.

Argynnis Paphix.

PLATE XIV. Fig. 1.

Pan. Paphin, Linn.-Donovan, vii. pl. 247, 5.-I iewin. pl. 9.

I'HIs species is usually of a larger size than either of the two preceding, but it bears considerable resemblance to them in the colour and markings of the surface. The upper side is a bright yellowish-brown (tinged with green in the female), variously streaked and spotted with black. Beyond the middle of all the wings, there are three series of black spots, which are of a rounded form in the two innermost rows, and angular in the marginal one. The primary wings are paler on the under side, many of the black spots indistinctly marked, and the tip slightly tinged in certain places with green. The secondary wings are green, with a brassy lustre, and ornamented with four transverse streaks or irregular bands of silver. white, the two next the base abbreviated, and the fourth occupying the hinder margin; the space between the two hinder bands is tinged with yellow, and bears traces of the two superficial rows of spots. The body is covered with hairs the colour of the 
wings, changing into yellowish-green in certain lights. The under side of the antennæ, and the apex of the club, are ochre-yellow.

The caterpillar is light brown, yellowish on the back, with two dark lines along the sides; the spines are long and hairy, and two placed on the first segment just behind the head, are considerably longer than the rest. (See Plate III. Fig. 5.) It feeds on the dog's violet and raspberry. The perfect insect is not uncommon in nearly all parts of England, and is found also in Scotland, but much less frequently. 


\section{Genus VANESSA.}

In this genus the antennæ terminate in an oval club; the palpi approximate at the extremity, and project obliquely, forming a kind of beak in front of the head : the basal joint is short and curved, the second very long and tapering, and the terminal one slender and conical: the wings angular, or having projecting points on the hinder margin; legs alike in both sexes; the anterior pair not formed for walking, the tarsus being composed of a single compressed spatulate piece, and densely clothed with long hairs; the four posterior tarsi terminating in double claws, with a minute heart-shaped appendage between them. The caterpillars are armed with long spines, but have the segment next the head naked. The chrysalis is angular, with two projecting points on the head, and is suspended by the tail. Several of the Vanessæ are among our most common insects, and they are surpassed by few in the beauty and variety of their colours. The wings are thick and of a rigid texture, and the body so much more robust than in the generality of their tribe, that they frequently pass the winter in a kind of dormant state, and again take wing on the returning warmth of spring. They present some differences in the structure of their oral organs, and ought perhaps, is strict propriety, to form two or three subgenera. 


\section{COMMA BUTTERELY.}

Vanessa C-album.

PLATE XVII. Fig. 1.

Papilio C.album, Linn._Donovan, vi. 45, pl. 199.

THIS is the smallest species of the genus inhabiting Britain, and differs considerably from the otners in the form of the wings. The colour of the upper side is reddish-yellow, generally darker in the maie than in the female, irregularly spotted with black, and having the hinder margin dark brown; two of the largest spots on the upper wings are placed on the anterior border, the others, four or five in number, occupy the disk; on the under wings there are usually three irregular black spots or patches. The colour of the under side is dark brown, often inclining to yellow, the basal half of the wings and the apex being darkest; on the paler portion of the anterior pair there is an obscure band of green, and two indistiner rows of greenish ocelli may be traced across both wings, not very far from the outer margin : the hinder wings have a short curved line of pure white near the middle, resembling the letter $\mathrm{C}$ reversed, from which the species derives its name. 


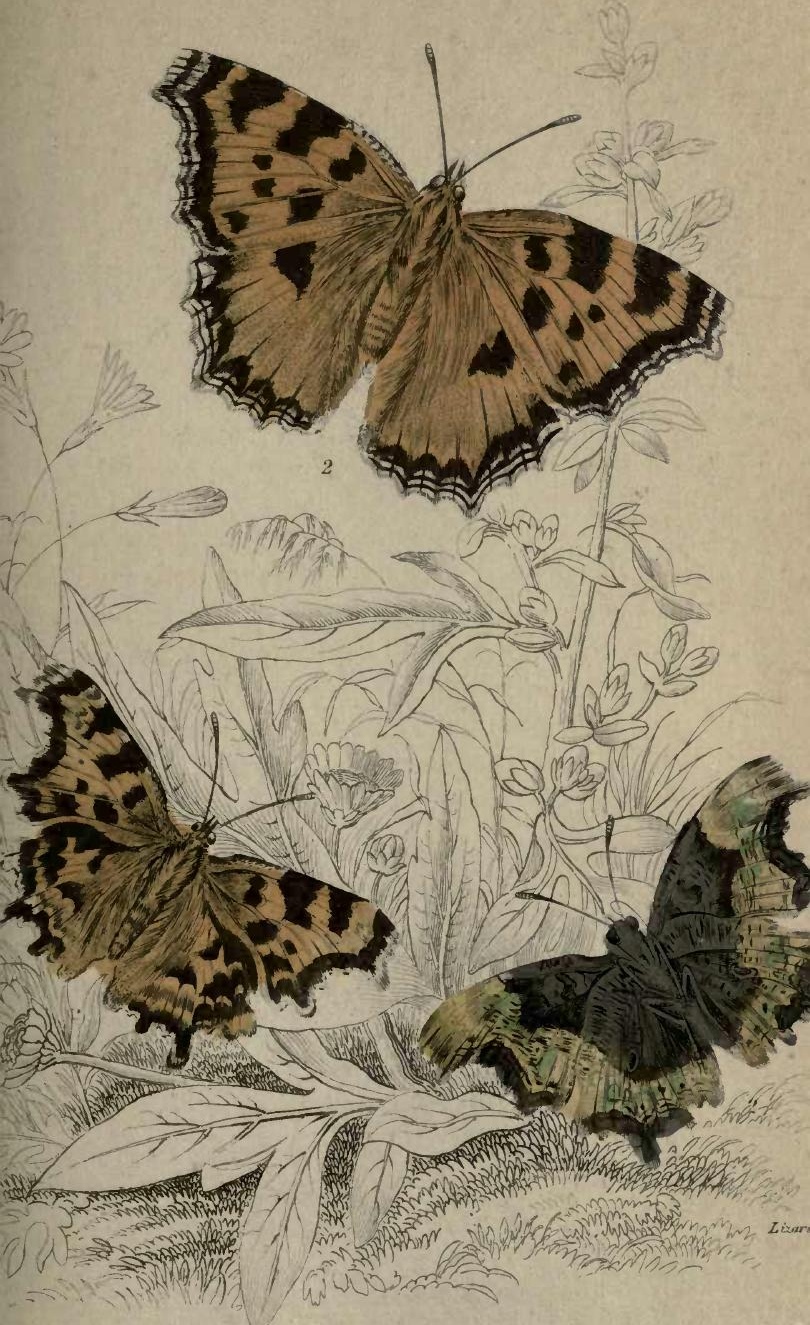

1. Virresirn $C$ allium. Comma $B$.
2 Vimessan pulithleros

Large Fortoise-shell B. 




ㄴ. 
The antennæ are black above, and brown with white rings beneath ; the club tipped with yellow.

The colour of the caterpillar is brownish-red, with a broad dorsal band of white extencling from before the middle to the hinder extremity. The head is nearly heart-shaped, and bears two large hairy tubercles, one on each side, resembling ears. It consumes the foliage of various trees, shrubs, and herbaceous plants, such as the elm and willow, the currant, hazel, honeysuckle, and the common nettle. The fly is by no means of frequent occurrence in Britain, at least in certain years, and does not appear to extend far north, although we have heard of its having been seen in Fifeshire in Scotland. It has been found abundantly near Hertford, in Suffolk. in the neighbourhood of York, and occasionally in most of the midland counties of England. The first brood appears in the end of June or beginning of July, and the second in September. Such as are produced late in the year, are usually of a much paler colour than those of the early summer. The insect is very common in most parts of the Continent, and is known in the French provinces, and has been described by Geoffroy, under the name of $\boldsymbol{R o}_{0}$ bert le diable! 
GREAT TORTOISE-SHFI.I.

Vanessa polychloros.

PLATE XVII. Fig. 2.

Pap. polychloros, Linn.-Donovan, viii. 69, pl. 278.

THts species bears considerable resemblance to $V$. Urticae in its colour and markings, but it is usually much larger, the expansion of the wings sometimes exceeding two inches and a half. The upper side is dark orange, inclining to ochre-yellow towards the anterior margin, and at the sides of some of the spots. The upper wings have two large quadrate black spots, like abbreviated bands, on the anterior margin; two smaller spots, placed obliquely, towards the base; two small rounded ones on the disk, and another near the hinder angle. The hinder wings are marked with a single black spot of considerable size near the middle of the anterior margin. Both wings have a deep border of black externally, ornamented with a series of crescents, which are pale in the anterior pair, but blue in the others, and bounded by two parallel lines of pale yellow. On the under side, the basal half of all the wings is dark brown, the remainder yellowish-grey, finely marked with 
undulating lines of brown, and an obscure row of bluish crescents towards the tip. Three pale spots are observable on the anterior part of the upper wings, and one near tne middie of the hinder pair.

"The caterpillar is bluish or brownish, with a lateral stripe of orange; the spines are slightly branched and yellowish. While young, these larvæ live together under a silken web, which they spin for their protection; but they disperse after they have changed their first skin. They feed on the wiilow and elm, and also on some kinds of fruittrees, particularly the cherry. The chrysalis is flesh-coloured, with golden spots near the neck."*

Although abundant in most parts of the continent of Europe, the Great Tortoise-Shell (or Elm Butterfly, as it is sometimes called), cannot be ranked among the most common of our day-flying Lepidoptera ; at least, it is scarce in many districts, and appears in plenty in others only in certain years. It occurs in all the southern counties of England, and in the Isle of Wight; we have traced it as far north as Dunkeld, and have seen notices of its having been frequently observed in many of the intermediate counties. There seems to be but one flight in the season, which usually takes place about the middle of July. On the Continent, it appears both in spring and towards the close of summer.

- Fncyclop. Methodique: Papillon, p. 305. 
SMAI.L, TORTOISE SHEIL.

Vanessa Urtace.

PLATE XIX. Fig. ’.

Pap. Urticæ, Linn. \&c.

THE prevailing colour of the upper side is orangered, inclining to yellow, especially on the anterior margin; the latter is marked with three large quadrate black spots, placed obliquely, beyond which there is a small white mark ; towards the middle of the hinder margin there is another large black spot, and two small round ones on the disk; the hinder margin is widely bordered with black, and ornamented with a series of blue crescents, and two undulating lines of pale yellow : the basal half of the under wings is black, the rest orange red, except the hinder margin, which resembles that of the anterior wings. On the under side the anterior wings are pale yellowish, with three large patches of dark brown towards the base; the tip mottled with brown and marked with an indistinct row of dusky crescents : the basal portion of the under wings is darkbrown beneath, with a small white dot in the middle, the rest light-grey, mottled with brown, and marked with an indistinct row of bluish-black triangular 


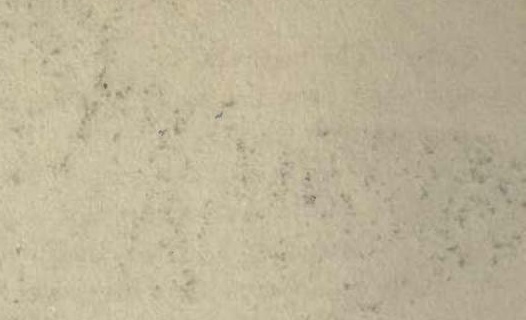

REESE LIBRAPY
OF THE TITY
UNIVERSITY
CALIFORNIA.

3. 
spots. The body and base of the wings are clothed with long brownish hairs, and the antennæ are variegated with white.

The caterpillars of this species feed on the nettle, and for some time after they are excluded from the egg, live together in little family associations, but disperse as soon as their increasing size renders a larger supply of food necessary. They are of a blackish colour, with four yellowish stripes, two along the back, and one on each side; the body beset with strong branched spines.

This is by far the most common insect of the genus, occurring abundantly in all parts of England, and extending to the northern extremity of Scotland. Considerable numbers pass the winter in a torpid state, and issue from their retreats on the first warm days of March. In the south of Scotland, where it is known by the name of the Devil's Butterfly, and Witch's Butterfly, we have occasionally observed it on the wing even before that period, and it has been noticed in the Isle of Wight on the 8th of January.* There appear to be at least two broods annually, one in June, and another in September. In the south of Enrope it is likewise a prevalent species, and in Italy it continues on the wing in fine weather the whole winter. Its metamorphoses are admirably delineated by Swammerdam unde the name of the Common Dutch Day Butterfly. $\dagger$

" Loudon's Mag. of Nat. Hist. v. p. 595.

+ Book of Nature, pl. xxxiv. and xxxv. 
PEACOCK'S EYE.

I'anessa Io.

PLA'TE XVIII. Fig. 1.

Pap. Io, Linn._Donovan, vi. 67, pl. 206.

TrE colour of this elegant insect is deep brownish-red, inclining to purple, with a large eye.like spot on each wing. On the anterior wings, this spot is placed near the apex, and is composed of a yellow crescent on the inner side, a semicircular patch of blue externally, and a large reddish-brown pupil, which becomes darker anteriorly, where it unites with the black margin. On the outer side of the pupil, there are three small spots of a whitish-blue colour, forming an irregular line with two others placed in the red portion of the wing. The ocellus is bounded internally by a triangular patch of black, next to this is a yellow spot, succeeded by a black triangular one, which does not reach the anterior margin; the latter towards the base is yellowish, with transverse lines of black. The ocellus of the hinder wings consists of a large black central patch, spotted with blue, and encircled by a zone of pale silky-brown, whirh is bounded anteriorly by a large 


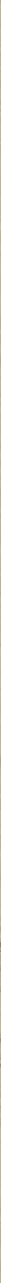






ㄴ. 
black crescent. The under side of the wings is shining dark-brown, with transverse undulating lines of deep black, the five bluish-white spots of the upper wings appearing as pale points, and another similar spot is observable in the middle of the hinder wings. The body is blackish, and clothed with rust-coloured hairs : the legs dull yellow.

The caterpillar feeds on the two common species of stinging nettle. It is of a shining black colour, with numerous white points somewhat disposed in transverse lines, and having the hinder legs rust-red.

This highly beautiful insect, which the earliest of our British naturalists styles "onnium regina," is much less extensively distributed than the preceding species. Although abundant in most parts of England, there appear to be certain districts even in the south where it is not common, and it gradually becomes scarce as we advance northwards. The most northern place where it has occurred in plenty, is the vicinity of York, and it probably does not extend beyond the Frith of Forth. Throughout the south of Scotland, indeed, it is seldom seen, although it nas been stated, through some mistake, to be a common species in that quarter. We know it to have occurred sparingly near Edinburgh, and also in Roxburghshire and Dumfriesshire. 
CAMBERWELL BEAUTY.

\section{Vanessa Antiopa.}

\section{PLATE XVIII. FIG. 2.}

Papilio Antiopa, Linn._Donovan, iii. 45, pl. 89.-Levin, pl. 1.-The Willow Butterfly, Wilke's English Butterfies, pl. 113.-Curtis, B. E. ii. 96.

THIs is one of the largest of our indigenous butterflies, the expansion of the wings sometimes exceeding three inches. The upper side of both wings is a uniform deep purplish-brown, having the appearance of velvet, bounded externally by a broad band of velvet-black, in which are placed a series of pretty large violet-blue spots, of an oblong shape on the hinder wings, but usually with a tendency to a crescent form in the anterior pair : beyond this there is a broad cream-coloured border, slightly waved on the inner side, and sprinkled with minute black points, especially on the salient angles. The anterior border has two cream-coloured spots beyond the middle, and is mottled with yellow towards the base. The under side is shining dark brown, with transverse waved lines of deep black, and a small yellowish spot near the middle of each wing, and two larger ones on the anterior border. 
The caterpillar, like most of those belonging to this genus, is gregarious, and consumes the foliage of various trees, particularly the birch, willow, and poplar. The colour of its body is black, with a series of spots along the back, and the eight interme diate legs red.

"This fine species," says Mr Curtis, "is rendered rare and remarkable in this country by its periodical appearance, the cause of which has never hitherto been ascertained. The most probable conjecture is (as Mr Haworth has observed), that 'their eggs in this climate, like the seeds of some regetables, may occasionally lie dormant for several seasons, and not hatch until some extraordinary but undiscovered coincidence awake them into active. life.' Until four or five years since, $V$. Antiopa had not been seen for nearly forty years, when it was exceedingly abundant in different parts of the kingdom. In the year 1819 , a few were taken in Suffolk, and Mr Samouelle captured one the following spring that had lived through the winter, since which period it has not been seen. It has received its English name from having been first observed at Camberwell, whither it might have been attracted by willows, upon which the larvæ feed. The butterfly is found in the beginning of August. It frequents woods, and is strong and rapid in flight."*

"This species has been once taken in Scotland, near Beith in Ayrshire." James Wilson, Esq.

* British Entom. ii. 96. 
ADMIRAL REI).

Vanessa Atalanta.

PLATE XX. Frg. I.

Pap. Atalanta, Linn.-Donovan, viii. pl. 260.-Lewin, pl. 7. -Pap. major nigricans, \&c. The Admiral, Ray's Ins. 126. - The Admirable, Albin, p. 3.-Admiralis Atalanta, the Alderman, Rennie.

THE upper side of this beautiful insect is deep black, with a fine silky gioss: the upper wings have a broad band of red running from the anterior margin obliquely across the surface nearly to the hinder angle, where it is considerably incurved, beyond which are six white spots, small and rounded, except the two at the anterior margin, of which the inner one is large and quadrate, and the other somewhat crescent-shaped; beyond these there is a faint bluish streak parallel with the apical margin : the under wings have a broad border of red behind, in which there is a series of small angular black spots, and two semicircular patches of blue at the inner angles. On the under side of the anterior wings the oblique band is ochreous-red, becoming paler at the hinder extremity; towards the base of the wing there is a narrow waved streak of blue, and two others of 




Whall

A-

$$
\begin{aligned}
& 1 \text { J S. }
\end{aligned}
$$

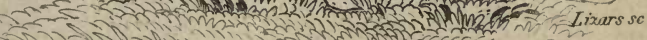



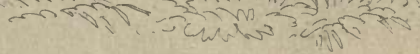

1.Tanessa Atalanta Red Admiral.

\section{Limeutrs Camilla} White Admiral. 




난

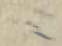


red, one of which is united to the central band; beyond the latter are two irregular blue streaks, and the extreme tip of the wing is of a tawny colour, in which are two of the smaller white spots surrounded with a dusky ring: the linder wings are finely marbled with undulating lines and spots of black, brown, and yellowish-grey, the latter forming a large patch near the middle of the anterior edge. The fringe of the wings is white, interrupted with black.

The caterpillar is solitary, and feeds on the nettle. It prefers the seed of that plant to the leaves, and usually protects itself from the weather by drawing a few leaves around it, which it secures by silken threads. It is greenish, or nearly black, with a macular line of yellow along each side.

It is common in England, and occurs in some plenty apparently in all parts of Scotland. It is most frequently seen towards the end of autumn, and delights to alight on the flower of the dahlia, or some late flowering aster. It is found in all parts of Europe, in the United States of America, and the countries of Africa skirting the Mediterranean. In the East Indies, and in the island of Teneriffe, it is re placed by a very closely allied insect, which beautifully exemplifies the nice and occasionally almost imperceptible gradations by which nature sometimes passes from one species to another. The latter is named vulcania, and the distinctive marks which it presents are so slight, that they might seem rather between those few days that intervene from the end 
a casual modification of the characters of $V$. atalanta, - than the indication of any specific difference; yet tho two have a totally different range of geographica distribution.* "This insect very rarely appears," says a popular writer, speaking of $V$. atalanta, " until late in September, and then so perfect and fresh in its plumage, as to manifest its recent production from the chrysalis. In some years they abound, and we may see twenty of these beautiful creatures expanding and closing their brilliant wings under the fruit trees on our walls, or basking upon the disc of some autumnal flower; and at another, perhaps, hardly a specimen is to be obtained; nor do they seem, like the wasp, to be scarce or abundant according to the deficiency or plenty of the season, but influenced by other causes. Many of our butterflies are produced by successive hatches, supplying the places of those which have been destroyed, and here it is difficult to mark the duration of an individual; and others, as the nettle, peacock, and wood tortoise, in many instances survive the winter, hidden in some recess or sheltered apartment, appearing in the spring time-worn and shabby. But $V$. atalanta appears only in the autumn, not as a preserved creature, but as a recent production; and hence we can ascertain the duration of its life to be comprised only

* A figure of V. Vulcania will be found in Loudon's Mag. of Nat. Hist., v. p. 752, where it is described by an intelligent observer as intermediate between $\boldsymbol{V}$. Atalanta and $\boldsymbol{C}$. Cardui. Both Cramer and Herbst have figured it as a variety of $\boldsymbol{V}$, atalanta. 
of September to the end of October, by which time its food in our gardens has pretty well disappeared. Some sheltered wall, garnished with the bloom of the ivy, may prolong its being a little longer, but the cold and the dampness of the season soon destroy it, rendering the life of this creature. the most beautiful of our lepidopterous tmbes, of very brief duration."*

- Journos os a Naturasist, p. 290. 
PAINIED LADY.

\section{Cunthin Candui.}

PLATE XIX. Fig. 2.

Par. Cardui, Linn.-Donovan, ix. pl.292.-Lewin, pl. 6.Vanessa Cardui, Samou._Curtis.-The Painted Lady, Wilkes, pl. 107.-Harris, Aur. pl. 11.

THe genus Cynthia approaches so closely to the foregoing, that if it is held to be distinct, it can only be regarded with propriety as a subgenus. The chief difference is in the form of the wings, which in Cynthia are scarcely angular, and the hinder pair are rounded and simply scolloped without any projecting lobe. The club of the antennæ is very short and abrupt, and the palpi are long, gradually narrowing to a point. The upper wings of the only species found in Britain are tawny-brown at the base, the middle ochre-red, inclining to carmine, with a very irregular transverse patch of black, and a large portion at the apex black, adorned with five white spots, the inner one largest, and placed obliquely, the others somewhat rounded, and the two in the middle rather minute. Near the margin 
there is an indistinct series of white crescents, beyond this a row of faint yellow spots, and the fringe is white, interrupted with black. The secondary wings are tawny brown at the base and inner side, and black anteriorly, the remaining portion ochreyred, spotted with black, the latter forming three rows behind ; the first consisting of five round spots, some of them indistinctly ocelliform; the second of a series of crescents, and the third of pretty large patches placed on the projecting points of the hinder border. The anal angle is ornamented with a pretty large black spot, with a streak of blue behind. On the under side, the primary wings are whitish at the base, and have a large spot of that colour anteriorly, in addition to those that correspond to the upper side; the tip is light brown, the two smallest spots encircled with black, which makes them resemble ocelli; and the whole disk is tinged with a beautiful tint of carmine, deepest towards the base, and intermixed with ochre-yellow externally. The under side of the hinder wings is delicately variegated with light-brown, greyish-white, and yellow; the darker portions intersected with white ramifications, in such a manner as to produce in some places the appearance of leaves springing from a stem. Towards the hinder extremity there is a row of five ocelli, the outer one small and obsolete, that next to it and the innermost one being largest, and powdered with blue in the middle, the intermediate two powdered with green : a row of purplish-blue crescents is placed be- 
nind these, and the extreme margin is brownish-yellow. The body is clothed with reddish-brown hairs above, and with white beneath.

The caterpillar is very spiny, of a brownish-grey colour, with interrupted yellow lines along the sides. It is solitary, in this respect differing from all those of the genus Vanessa except $V$. atalanta, and feeds on different species of thistle, also on the nettle, mallow, artichoke, and several other plants. The chrysalis is nearly of the same hue as the larvæ, and thickly spotted with gold.

This species is generally scarce, but appears in certain indefinite periods in considerable numbers. It was very abundant near London in 1826 , but has been less frequently met with since. "Near Durnam, but not common," G. Andrews, Esq. In Scotland it is seen occasionally throughout the southern division of the country; and we once saw several individuals in the Edinburgh Botanical Garden, in the end of March, which had evidently just issued from their winter retreat. It is very widely spread, being found in America, the two extremities of Africa, and in Java. 



Aputirira Iris.

Purple Emperor. 
REESE LIBAAPY
OF THE
UNIVERSITY
CALIFORNIA.

ㄴ. $=$ 


\section{PURPLE EMPEROR.}

Apatura lris.

PLATE XXI.

Pap. Iris, Linn.-Donovan, pl. 37. $\delta$-Lewin, pl. 16.-The Purple Emperor, Harris.-Purple Highflyer, Wilkes.

Antenna long, the club elongate-ovate and concave : palpi long, and projecting beyond the head, where they meet and form a kind of beak; the basal and terminal joints nearly of equal length, the latter conical, the intermediate one very long, slender, and curved : wings somewhat triangular, the edge of the primary pair nearly entire, the others slightly scolloped: eyes not pubescent; the anterior legs small and imperfect in both sexes. The caterpillar has the head divided behind into two long horns (Pl. III. fig. 6). The chrysalis has the head piece bifid, and is suspended by the tail.

The surface of the wings, in the species above named, is dark brown, changing when seen in certain lights into purplish-blue of a very rich tint. This brilliant reflection is not visible in the female, and that sex is also distinguished by the wings being of a paler brown, and having two a 
ditional white spots towards the outer extremity of the upper wings. In both sexes there are four macular patches of white on the upper wings, the two outermost consisting of two small spots each, the twe innermost more continuous, but somewhat curved and interrupted at the nervures. The largest of these patches is placed in a line with a bar of white, which traverses the under wings in an oblique direction, emitting a salient angle near the middle of its outer edge. Midway between this band and a pale tawny streak which circumscribes the wings not far from the margin, there is a round black spot surrounded by a ring of ochre-red: a streak of the latter colour is also observable at the anal angle, and on the extremity of the adjoining nervure. On the under side, the upper wings are rust-brown, inclining to black in the middle, with a large ocellus towards the hinder angle, and two black spots not far from the base, in addition to the white marks corresponding to those on the upper side; the under wings, have the transverse white band rather broader than above, and the ocellus appears smaller; the base and hinder portion are greyish, with something of a pearly lustre, and a faint undulating brown line runs along the margin. The body is black above, the under side and legs greyish-white.

Both the caterpillar and chrysalis are pale green ; the horns of the former reddish at the tip, and having a yellow stripe down the outer side It feeds on the common sallow and oak. 
This fine insect, which is highly prized by collectors both for its beauty, and the difficulty with which it is obtained, has been occasionally found in many of the southern counties of England, but it does not extend far to the north. It has been found in some plenty in Coombe-wood, Great and Little Stour Woods, in Essex, Dodnash and Raydon Woods, in Suffolk, \&c. Owing to the strength and thickness of its wings it is enabled to fly with greater velocity than any other British butterfly, and to maintain a lofty and continuous flight almost like the soaring of a bird of prey. Its habits have been so well described by Haworth in his Lepidoptera Britannica, that we cannot refrain from extracting the passage. "The Purple Emperor of the British Oaks is not undeservedly the greatest favourite of our English Aurelians. In his manners likewise, as well as in the varying lustre of his purple plumes, he possesses the strongest claims to their particular attention. In the month of July he makes his appearance in the winged state, and invariably fixes his throne upon the summit of a lofty oak, from the utmost sprigs of which, on sunny days, he performs his aerial excursions; when the sun is at the meridian, his loftiest flights take place, and about four in the afternoon he resumes his station of repose. He ascends to a much greater elevation than any other insect, sometimes mounting higher than the eye can follow; especially if he happens to quarrel with another Emperor, the monarch of some neighbouring oak: they never meet 
without a battle, flying upwards all the while, and

- combating with each other as much as possible, after which they will frequently return again to the identical sprigs from whence they ascended. The wings of this fine species are of a stronger texture than those of any other in Britain, and more calculated for that gay and powerful flight which is so much admired by entomologists. The females, like those of many other species, are very rarely seen on the wing; in three days I captured twenty-three (nine of them in one day), and never took a female at all. The males fly very high, and are only to be taken by a bag-net, fixed to the end of a rod twenty or thirty feet long. There have been instances, though very rare, of their settling on the ground near puddles of water, and being taken there. When the Purple Emperor is within reach, no fly is more easily taken; for he is so very bold and fearless, that he will not move from his settling-place until you quite push him off; you may even tip the ends of his wings, and be suffered to strike him again." 
WHITE ADMIRAL.

Limenitis Camilla.

PLATE XX. Fig. 2.

Pap. Camilla, Linn._Curtis, Brit. Ent. iii, pl. 124.-Dono van, viii. pl. 244.-Lewin, pl. 8.-White Admiral, Petiver and Curtis.-The White Admirable, Harris' Aurelian, pl. 30 .

AnTENn thickening gradually from near the middle almost to the apex, the club being slencler and elongated; palpi not approximating at the tip, the basal joint shortest and nearly oval, the second one very long, and the terminal one elongate-ovate, ending suddenly in a point; wings not much longer than broad, rounded and entire ; eyes pubescent ; legs alike in both sexes, the anterior pair short and slender, the tarsus formed of a single joint ending in a small claw, the other claws nearly resembling those of Vanessa. Caterpillar with obtuse fleshy projections on the back, fringed with hair (PI. III. fig. 7). Chrysalis bifid at the head, and suspended by the tail.

This elegant insect is about the size of larger specimens of the Small Tortoise-shell Butterfly, the expansion of the wings being nearly two inches. The 
colour is dull black above, variegated with obscure dark spots. Both wings are traversed by a broad oblique white band, which is very irregular on the upper pair, being widely interrupted in the middle, and divided by the nervures into separate spots, the anterior portion directed inwards; where the band is interrupted, there is a minute white spot, and a larger one on a line with it externally; two others are placed near the tip, and a fourth midway between the white band and the base of the wing. On the hinder wings the band is attenuated towards the anal angle ; on the latter is a patch of rust-red surrounding two black spots, and two rows of obscure dark spots occupy the space between the band and the hinder extremity. The prevailing colour on the under side is brownish-yellow; all the white spots of the upper side are visible, with the addition of a few others, and most of them have a faint pearly lustre. The base of the hinder wings, and under side of the body, are pale blue, and the yellowish-brown portions are streaked and spotted with black. The fringe is white, spotted with black; the antennæe rust-brown on the tip and under side.

The caterpillar, which does not appear to have been observed in England, is described by the continental naturalists as green, with the head, dorsal appendages, and sides of the belly reddish. The honeysuckle is its favourite food.

Like the preceding species, this insect must be placed among our rarer British Butterflies. Some 
of the south-eastern counties of England formerly produced it in tolerable plenty, but of late years it has been nowhere abundant, although it has been noticed in a considerable number of places. The following localities may be cited :-Woods near Rye, Sussex, New Forest, Coombe-wood, Hartley-wood, Essex, Berkshire, and Suffolk. It does not appear to inhabit the north of England nor Scotland. Few butterflies are greater favourites with aurelians than this, and none have been more highly eulogized for the gracefulness of their flight. "The graceful elegance displayed by this charming species," says Mr Haworth, "when sailing on the wing, is greater perhaps than can be found in any other we have in Britain." "In its beautiful flight," says another writer, "when it skims aloft, it rivals the Purple Emperor, which it strongly resembles in appearance. It seems, however (unlike the latter), to avoid the sunbeams, for it frequents the glades of woods, where it rapidly in- sinuates itself by the most beautiful evolutions and placid flight through the tall underwood on each side of the glades, appearing and disappearing like so many little fairies." * The insect is not rare on the Continent, where there likewise occur four others pertaining to the genus, some of them very closely resembling the present species.

- Rev. Revett Sheppard, in Miss Jermyn's Butterfly Collectors' Vade Mecum, 2d edit. p. 121. 


\section{Genus HiPPARCHiA.}

Witu the exception of Polyommatus, which approaches it in the number of species, this is by far the most extensive genus among the British Butterflies. As at present constituted, however, it is not of a very homogeneous nature, several of the insects which it includes not only differing considerably from each other in habit, but also in the form of the wings, the proportions of the joints of the palpi, and other essential parts of structure. None of the indigenous kinds are remarkable for the brightness of their colours, the prevailing tints being deep brown, relieved and variegated with ochre-yellow and brownish-red; and the under side is often ornamented with eye-like spots. The caterpillars are almost invariably of some shade of green, and are thus assimilated, no doubt with a view to their safety, to the colour of the plants on which they feed, viz. the different kinds of grasses. Their bodies are nearly naked, or covered only with short hairs, and there are two projecting points behind, which make the anal extremity appear bifid. The antennæ are variable in length, the club generally spindle-shaped, or tapering at both ends, and curved; in H. semele, 
however, it is short and abrupt. The palpi are longer than the head, rather remote trom each other, and not converging, the point curving downwards ; the radical joint short, the terminal one, in certain species, not half the length of the second, and obtuse, while in others it is more than one half longer than the second, and acute at the apex. The anterior wings are sometimes angular, at other times rounded, the hinder pair denticulated in most, but entire in H. Cassiope, Davus, Hero, and Pamphilus; the basal areolet of the secondary wings closed. The fore-legs are very short in both sexes, the others with bifid claws. The chrysalis is double-beaked, and is suspended perpendicularly. 


\section{SPECKLED WOOD BUTTERFLY.}

\section{- Hipparchia Ageria.}

PLATE XXIII. FIG. 4.

Pap. Ægeria, Linn.-Dononan, xiv. 77, pl. 498.-Lewin, pl. 19.-Wood Argus, Wilkes.-Speckled Wood Butterfly, Harris.

THE upper side is brown, the anterior wings with ten or eleven pale yellow spots on each, placed irregularly, and having a black ocellus with a white pupil towards the apical angle. The hinder wings have one or two yellow spots anteriorly, and a row of eyes parallel with the hinder margin. These are four in number, and consist of a round black spot, with a white pupil, surrounded by a yellow ring; the anterior one being much smaller than the others, and without a pupil. The fringe of both wings is pale yellow, the dark colour of the wing interrupting it at the nervures, and making it appear like a series of crescents. The under side of the wings is pale yellow, clouded and streaked with brown; the hinder pair with undulating transverse lines, and a row of five pale dots, encircled with brown, the space between which and the outer margin is sometimes 
glossed with violet. The upper and under sides of the body are concolorous with the corresponding faces of the wings.

The caterpillar is covered with a matted pubescence of a green colour, and marked on the sides with yellow or whitish lines. It feeds on various grasses, but prefers the common couch-grass.

The Speckled Wood Hipparchia is a vernal species, the first flight taking place in the beginning of April. This is succeeded by two others, one in June, the other in August. It appears to extend over all Britain. It is included in a list of Papilionida found near Dover; ; we have received it from the north of Scotland, and have often seen it in the neighbourhood of Edinburgh, in Roxburghshire, and other southern counties, and it is far from scarce in most parts of England. From the notices we have received, however, it appears to be rather scarce in the vicinity of Newcastle and Durham.

- Lounnn's Mag. Nat. Hist. vol, $\boldsymbol{b}$. 
188

WALL BUT'TERFLY.

Hipparchia Megara.

PLATE XXII. FIG. 3.

Pap. Megæra, Linn. Donovan, viii. pl. 279.-Orange Argis, Lewin, pl. 21.-Great Argus, Wilkes.-Wall Butterfiy, Harris.

THE greater part of the anterior wings is orangeyellow inclining to brown, with the hinder margin, and several transverse irregular bands on the disk, dark-brown; each wing with a large ocellus towards the tip, with a black iris and white pupil, sometimes having a smaller one adjoining. The hinder wings are dark-brown, with two transverse patches or bands posteriorly, that next the margin broadest, and bearing a row of ocelli, varying from three to five in number, the lateral ones frequently without a pupil. Beneath, the upper wings are pale, with the brown bands faintly marked; the ocellus, however, is large, and surrounded with a brown ring; the under pair nearly ash-grey, sprinkled with black points, and traversed by two narrow undulating brown lines, between which and the hinder margin there is a curved series of six ocelli, that next the anal angle being 
double; behind this there is a waved band of pale yellow. The fringe of the wings is whitish and brown alternately.

The caterpillar is vubescent. of a light green, with a whitish line on eacn side.

Far from being a scarce species. and apparently found in all parts of the country. It occurs in April, July, and August.

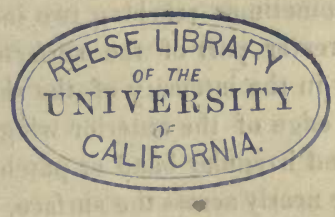


IHE GIRAYLING.

Hipparchia Semele.

PLATE XXII. FIGs. 1. \& 2.

Pap. Semele. Linn.-Donovan, viii. pl. 259 q.-Lewin, pl. 17.-The Gravling Butterfy, Harris.

ONE of the larger species, the expansion of the wing sometimes reaching two inches and six lines. The greater part of the surface is brown, varying greatly in the intensity of the shade. Towards the hinder edge of the anterior wings, the female has a wide and irregular band or patch of pale yellow, extending nearly across the surface, in which are placed two remote ocelli, with a white pupil and black iris; the male has merely a yellowish patch round each ocellus. The basal half of the hinder wings, as well as the posterfor border, is brown in both sexes, the intermediate portion being pale or reddishyellow, more or less obscured with dusky, and having a small ocellus with a white pupil towards the anal angle. On the under side, the anterior wings are tawny at the base, the anterior and posterior margins brownish, the latter marked with white; the disk is pale-yellow, and the two ocelli are conspi- 


\section{CALIFORMA}

?

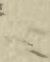


cuous: the posterior wings are clouded with white and dark brown, the basal half darkest, and the dark part terminating near the middle, in an irregular sinuated line; there is likewise a small ocellus corresponding to that on the opposite surface.

The caterpillar and chrysalis are both light-green, the former with brownish legs.

The butterfly frequents rocky and stony places, and occurs rather plentifully in such situations in most parts of the country. The rocky sides of Arthur's Seat, and similar localities throughout the south of Scotland, afford it in considerable plenty in certain years, and we have seen several examples from Sutherland and other northern counties. Among the numerous localities cited by English entomologists, we may mention Newmarket, Dartmoor, Nacton Heath in Suffolk, and Lexden Heath in Essex. In the neighbourhood of Newcastle, Mr Wailes informs us that it is almost confined to the magnesian limestone, and another correspondent states that it is not unfrequent in stony places near Durham, and in Castle Eden Dean, during the month of July. 


\section{MARBLED WHITE BUTTERFLY.}

Hipparchia Galathea.

PLATE XXIII. FIg. 1 .

Pap. Galathea, Linn.-Donovan, viii. 15, pl. 258. of Lewin, pl. 28.-Wilkes' English Butterfies, pl. 100.

THE colours of this handsome species are black and greenish-yellow, each of them occupying almost equal portions of the surface. The upper wings have a large somewhat oval yellow spot at the base, three large patches of the same colour near the middle, divided into spots by the black nervures, two small ones near the anterior angle, and a row of small points parallel with the margin; the fringe of the latter with alternating spots of black and yellow. There is likewise a large yellow spot at the base of the under wings, a broad irregular band of the same colour in the middle, traversed by the black nervures, and a row of small yellow spots near the hinder extremity. The under side is paler than the upper, the greenish-yellow colour greatly predominating, all the wings having a row of large triangular marks on the hinder margin. There is a small ocellus near the tip of the upper pair, and five others on the hinder wings, forming an irregular row, interrupted 


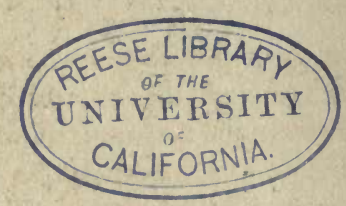


little beyond the middle; that next the anal angle is double. The body is black above, and densely clothed, as well as the base of the wings, with yellowish hairs. Varisties occur in which one of the colours occupies greater part of the wing: that in which the black predominates has been taken near Dover ; ${ }^{*}$ in the other, which has been named Leucomelas, the secondary wings are entirely white beneath.

The caterpillar is yellowish-green, with a dark line along the back, and another on each side. The head is reddish-brown, and there are two small spines of the same colour on the hinder extremity. It is found in May on the Timothy grass (Phleum pratense).

This pretty butterfly is regarded as very local, but its localities are pretty widely scattered over the south of England. It is usually found in moist glades, or in bogs and marshy ground, but sometimes frequents places of a very different description. The following are a few of the stations in which it has been observed in greatest plenty. Near Dover, Teignmouth, woods at Baylham Hall, Ipswich, Darenth Wood, \&c. It is likewise abundant near York, which is probably its most northern residence. as it is not known to occur in Scotland.

- This variety is figured by Esper (die Schmetterlinge, tab. iij, fig. 4), and a similar one is represented in Loudon's Mag. Nat. Hist. v. 335. 
LARGE HEATII.

Hipparchia Tithonus.

PLATE XXIII. FIGS. 2. \& 3.

Pap. Tithonus, Linn.-Pap. Pilosellæ, Fabr.-Donova, xii, pl. 405.-The Gate Keeper, Harris' Aurel., pl. 44.

UPPER wings ochre-red, or reddish-yellow, with the base brown, and the anterior and outer sides widely margined with dark brown. On the outer anterior angle of the reddish-yellow portion of the wing there is a pretty large round ocellated spot ol black, with two minute white points in the centre. The hinder wings are likewise brown, with a large reddish-yellow mark in the centre, which bears a minute ocellus on the side nearest the anal angle. On the under side, the upper wings are coloured as above, but the hinder pair are greyish-brown, with a very irregular cross band of light grey behind the middle, in which there are usually four minute white points approximating in pairs, and surrounded by a brown cloud. The male is considerably smaller than the female, more deeply coloured, and has a brown cloud in the middle of the coloured portion of the fore wings. 
The caterpillar, which teens on the annual meadow grass (Poa annua), is of a green colour, with a readish line on each side, and a brown head. The butterfly appears in June, and is of frequent occurrence in England, and many places in the south of Scotland, 


\section{MEADOW-BROWN BUTTERFL}

Hipparchia Janira.

PLATE XXIV. FIGs. 1. \& 2.

Pap. Janira, Linn. ơ.-Pap. Jurtina \&, Linn.-P. Jurtina, Donovan, ix. 69. pl. 320._Lewin, pl. 18.

THIs species is considerably larger than the preceding, the wings of the female sometimes expanding nearly two inches. The ground colour is brown, varying considerably in shade, but usually darkest in the male. In that sex, the upper wings are in general entirely brown, with a small ocellus towards the apex encircled with reddish-yellow; but in the female, there is a large transverse patch of ochre. yellow beyond the middle of the wing, in which is placed a large black ocellus, with a white pupil, and the space between this patch and the base is very obscurely tinged with reddish-yellow. The hinder wings are usually unspotted in the male, but those of the female have frequently an obscure yellowish mark in the middle. The under side of the primary wings is tawny-orange, with a paler band not far from the hinder margin, in which is placed an ocellus, as on the upper surface, sometimes having a 
PLATE 24.

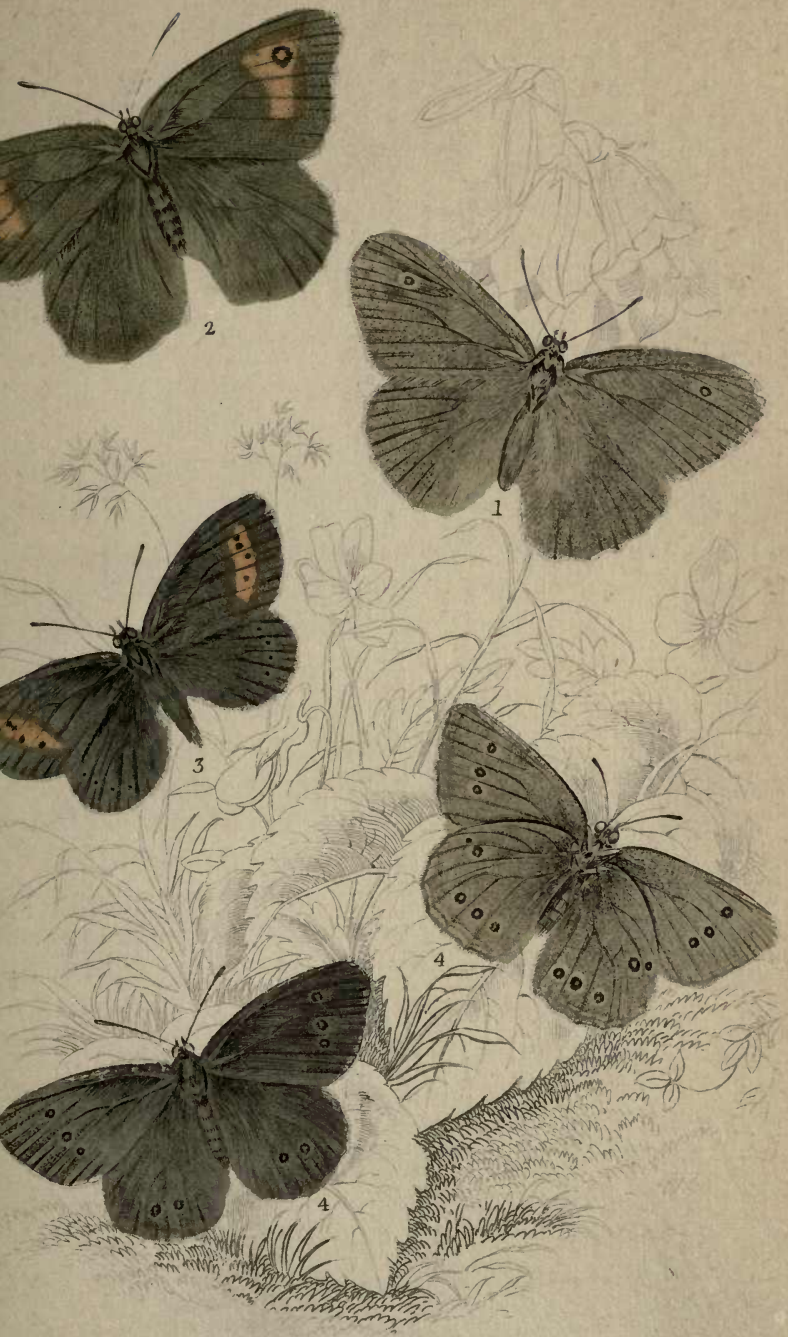



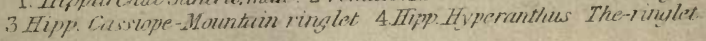




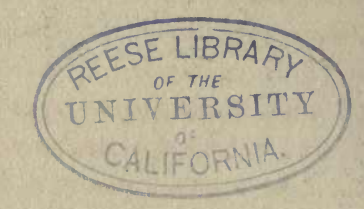


double pupil. The hinder wings are tawny-brown from the base to the middle, where the colour terminates in an angular line: the space beyond this is pale, excepting the margin, which is of the same colour as the base. The pale portion sometimes bears two or three small black eye-like spots, and the whole surface seems as if dusted with black.

Both the caterpillar and chrysalis are light green, the former with a white line along each side, and the latter streaked with brown. It feeds on several common grasses, particularly the Smooth-stalked Meadow-grass (Poa pratensis). The butterfly is first seen on the wing in the beginning of June, and, next to the White Cabbage species, may perhaps be regarded as the most common insect of its tribe inhabiting Britain. "A Amid the tribes of insects," says Mr Kapp, " particularly influenced by seasons, there are a few which appear little affected by common events: the Brown Meadow Butterfy, so well known to every one, I have never missed in any year; and in those damp and cheerless summers when even the White Cabbage Butterfly is scarcely to be found, this creature may be seen in every transient gleam, drying its wings, and tripping from flower to flower, with animation and life, nearly the sole possessor of the field and its sweets. Dry and exhausting as the summer may be, yet this dusky butterfly is uninjured by it, and we see it in profusion hovering about the sapless foliage. In that arid summer of 1826 , the abundance of these creatures 
was so obvious as to be remarked by very indifferent persons." *

\section{THE RINGLET BUTTERFLY.}

Hyparchia Hyperanthus.

- PLATE XXIV. Fif. 4.

Pap. Hyperanthus, Linn.-Donovan, viii. pl. 271.-The Ringlet, Harris' Aurel. pl. 35.

THE whole upper surface is of a uniform brown colour, generally without eye-like spots, but not unfrequently having two or three on each wing not very distinctly formed. The under side is pale brown, the anterior wings with two or three ocelli towards the tip, which are sometimes large and conspicuous, especially in the females, and occasionally almost obliterated: the hinder wings have usually five ocelli, variable in size, two of them placed close together towards the anterior margin, and three others in a line behind, the inner one being usually smallest. The body and base of the wings are clothed with dark-brown hairs; the fringe is light grey; and the antennæ variegated with white, and having the club of a rust-red colour.

The caterpillar feeds chiefly on the Annual Meadow-grass in this country: on the Continent it is - Journal of a Naturalist, p. 288. 
also found on the Millium effusum. It is greyishwhite, with a narrow brown line on the back; sometimes, however, it is entirely blackish.

This sombre-coloured, but not inelegant butterfly, is pretty abundant in all parts of Britain, frequenting meadows, the open parts of woods, and the sides of corn-fields. The variations which it presents in the magnitude and number of the ocelli are very numerous.

\section{MOUNTAIN RINGLET.}

Hipparchia Cassiope.

PLATE XXIV. Fig. 3.

Fabricius.-Pap. Mnemon, Haworth, Entom. Trans._Stephens's Illus. Haust. vol. i. pl. 8.-P. melampus, Herbst. -P. Alcyone, Borkh.

Much less than the preceding species, the wings expanding about 16 lines. The colour is dark brown, with a silky gloss, the upper wings having a red band towards the apex, somewhat interrupted at the nervures, and marked with a row of from three to five black spots : the short band of the hinder wings consists of a few continuous red marks, each bearing a small black spot. The under side of the anterio wings differs from the upper only in having the dis: 
more or less tinged with rust-red : the hinder wings are ash-brown beneath, at least in one of the sexes, baving three black spots behind, surrounded by a reddish iris. The fringe of the wings is brown; the antennæ black above and white below.

This species is readily distinguished from any of its associates by its inferior size. The red band on the wings varies greatly, and in some instances it is without black dots in the upper pair. The insect is very local in this country, almost the only localities being in the mountainous districts of Cumberland and Westmoreland. On the continent, it inhabits Switzerland, and the mountainous countries of the south of France, in considerable pienty. 
PLATE 25



1. Hipparchia Livea. 2. Hipparchia Blandina. Arran brown. 
REESE LIBRAAY UNIVERSITY CALIFORNIA.

2. 


\section{ARRAN BROWN BUTTERELY.}

Hipparchiu Ligea.

PLATE XXV. FIG. 1.

Pap. Ligea, Linn.-Stephens' Illust. of Brit. Ent. Haust. vol. i. pl. 6 .

In this species, the expansion of the wings is from eighteen to twenty-two lines. The colour of the upper side is brown, and there is an abbreviated reddish band towards the extremity of each wing On the upper pair, this band bears four black ocelli, with white pupils; the latter, however, are wanting in the male. The hinder band likewise bears three ocelli, presenting the same sexual difference. The under side is somewhat paler than the upper, the markings on the anterior wings not differing materially from those on the surface: the most striking peculiarity of the hinder pair is an irregular white band, widest near the anterior edge, wlich extends nearly across the wing; behind this are three round spots, composed of a red ring enclosing a black ocellus, with a white pupil. All the wings are surrounded with a white fringe, spotted with brown. The antennæ are white beneath. 
The caterpillar is green, blackish on the back, and having longitudinal white stripes on the sides.

The butterfly is very rare in this country. We nave not heard of any other locality than the Isle of Arran, where it was first found by Sir Patrick Walker ais d. NacLeay, Esq. It is ist an uncommon species in several northern countries of Europe, frequenting meadows and woods.

\section{SCOTCH ARGUS BUTTERFLY.}

Hipparchic Blandina.

PLATE XXV. Fig. 2.

Pap. Blandina, Fabricius.-Donovan, xii. 87. pl. 426.

T'He colour is brown, generally of a very deep shade, sometimes approaching to black. Each of the upper wings has a red band externally, which usually bears four ocelli, with bluish-white pupils, the two foremost being united ; one of them is occasionally obsolete, and they likewise vary in number. The red band on the hinder wings is short and indistinct : it is somewhat interrupted at the nervures, and has usually three small black ocelli, with white pupils. The markings of the upper wings nearly correspond on both sides; but the hinder pair, beneath, are crossed behind the middle by a broad irregular band 
of grey, inclining to blue, in which one or two minute ocelli are visible. In addition to this band, the female has the base of the wings and the hinder margin greyish. The fringe is light brown in the male, but inciining to white in the female, and interrupted with brown.

The caterpillar is light green, with brown and white longitudinal stripes; head reddish. The egg is ribbed, and of a whitish colour, speckled with brown.

This insect was first discovered in the Island of Arran many years ago, and has been found abundantly since in many parts of the country. It occurs in some plenty over a district of considerable extent in Dumfriesshire - near Minto in Roxburghshire-occasionally near Edinburgh, and probably in most of the southern counties of Scotland. In England, it has been found abundantly in Castle Eden Dean; and $\mathrm{Mr}$ Wailes informs us that it exists in profusion in one or two places in the magnesian limestone district not far from Newcastle. 
SCARCE SMALL RINGLET BUTTERFLY.

Hipparchia Davus.

PLATE XXVI. FIg. 1.

Pap. Darus, Fab.-Pap. Hero, Donovan, vi. pl. 186 Lewin, pl. 23, figs. 5. \& 6.

The expansion of the wings is from 15 to 20 lines; the colour of the surface obscure ochrey-yellow, inclining to brown, the fringe and interior edge of the hinder wings dull white : towards the hinder margin of the upper wings, there are usually two ocelli without pupils, and a curved row of three or four others, likewise without any central dot, not far from the hinder margin of the secondary pair. Beneath, the upper wings are brighter yellow than above, the apex greyish-white, each with a cross band of white beyond the middle, and exterior to it two remote ocelli, having a black iris and a white pupil, and occasionally a small imperfect one between them. The secondary wings underneath are very pubescent, greenish-brown from the base nearly to the middle, where that colour terminates in an irregular line, and is succeeded by a narrow and very unequal white band, usually interrupted; the space behind this is light brown, inclining to yellow, and orna- 
PLATE 26.


1. Hipparchia Jinves. Small Ringlet.

2. Pelvdamia Marsh Rinalet

3 Prmphilus smull Henth $B$. 


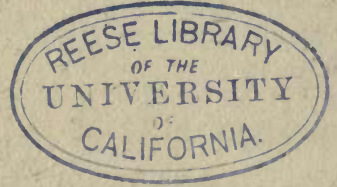

है 
mented with six ocelli, consisting of a black iris with a small silver-white pupil, and surrounded externally by a yellowish-white ring. In number and size the ocellated spots vary considerably, and the anal one on the secondary wings is sometimes double.

This scarce insect frequents marshes and moist heaths, and has occurred more frequently than elsewhere in the vicinity of Manchester, and on Shorn Moor in Yorkshire. Ashdown Forest has also been cited as a locality.

\section{MARSH RINGLET BUTTERFLY.}

Hipparchia Polydama.

PLATE XXVI. Fig. 2.

Hip. Iphis \& Polydama, Steph. Jermyn.-Pap. Typhon; Scarce Heath, Haworth.-Pap. Polydama, Haworth, Jermyn.-Pap. Tiphon, Esper.

ThIs species is about the size of the preceding, to which it is very closely related. The colour of the surface is rusty ochre-yellow, obscured with brown, the anterior wings frequently with one or two blind ocelli towards the hinder margin; the secondary wings greyish-white on the abdominal edges and round the outer margin, and fringed with rather long whitish hairs, usually bearing a blind ocellus neat the anal angle, and occasionally one or two others 
on a line with it. Underneath, the primary wings are greenish-brown at the base, rather bright yellowishbrown in the middle, and greyish at the apex, marked at some distance from the hinder margin with an abbreviated white bar, beyond which are generally two remote ocelli, with a minute silver-white pupil and black iris, encircled by a whitish ring; one of these ocelli sometimes obsolete. The basal half of the hinder wings is brown, with long greenish hairs ; beyond this there is a very irregular whitish band, sometimes interrupted, the space beyond which is greyish-brown (often with a fulvous cloud in the female near the middle), and five or six ocelli, some of them usually small and indistinct, and the anterior one sometimes placed in the white band. The antennæ are hrown above, ringed with white, the club tawny.

Caterpillar and chrysalis dark green, the former with a dark line along the back.

This insect, which may ultimately prove to be only a variety of the preeeding one, occurs not unfrequently on marshy heaths in the months of July and August. $\mathrm{Mr}$ Wailes finds it frequently in such situations near Newcastle: it also occurs near York, in North Wales, \&c. It was seen in great abundance last summer in Sutherlandshire, as well as in others of the more northern counties of Scotland, and we have received it from Argyll and Perthshire. 


\section{7}

SMALL HEATH BUTTERFLY.

Hipparchia Pamphilus.

PLATE XXVI. Fig. 3.

Pap. Pamphilus, Linn.-Lewin, pl. 23.-The Small Heath or Gate Keeper, Harris, Aurel. pl. 21._Golden Heath Eye, Petiver.

ThIs pretty little butterfly is very common in all parts of the country, on heaths and upland pastures. It appears first in the beginning of June, and there is a second flight in September. The expansion of the wings is usually about 13 or 14 lines : the colour of the upper side light ochre-yellow, the outer margin of the wings slightly dusky, and surrounded with a fringe of rather long whitish hairs. The primary wings on the under side are ash-coloured on che anterior edge and at the tip, the latter ornamented with a conspicuous black ocellus, with a white pupil, and a pale ring externally: the situation of this ocellus is indicated on the upper side by a dusky spot. The secondary wings are pubescent, green. ish-brown at the base, the centre ash-coloured, and the hinder part brownish-grey, with a few whitish points encircled by a yellow ring, which, however, are always indistinct, and often obliterated. The autennæ are brownish, with white rings. 
Both the caterpillar and chrysalis are greenish; the former somewhat dusky on the back, and having a white line on each side. It feeds on the Crested Dog's-tail Grass (Cynosurus cristatus).

Besides the above species of Hipparchia, the names of two others have been inserted in our indigenous lists, viz. H. Hero and H. Arcanius, on the doubtful authority of a single specimen of each, said to have been found many years ago by Mr Palstead. As both species are abundant on the continent, ex. tending even to the more northern parts of Sweden, it is not improbable that they may likewise inhahit this country, and we have therefore subjoined their distinctive characters.

\section{SILVER RINGLET BUTTERFLY.}

Hipparchia Hero.

Pap. Hero, Linn.-Pap. Sahacus, Fab.-Hipp. Hero, Curtis, B. E. v. pl. 205.

Brown, inclining to yellow. Upper wings pale anteriorly, with an orange stripe close to the posterior margin, near which are two small remote ocelli; the hinder wings with an orange stripe posteriorly, and four large ocelli, with black irides. On the under side, the primary wings are orange at the posterior margin, which is adorned with a silvery line, and two small remote ocelli; the secondary wings with a broad orange posterior band, enclosing 
five large and two small ocelli, forming a curved line, behind which titere 18 a narrow stripe of silver. Taken near Wythyham, on the borders of Ashdown Forest, Sussex.

\section{Hipparchia Arcanius.}

Pap. Arcanius, Linn.-Hipp. Arcanius, Jermyn.-Curtes, B. E. v. 205 .

"THE superior wings are fulvous on both sides, with the terminal border of a dark brown above, but lighter beneath, and having opposite the apex a sinall ocellus with a white pupil and yellow iris. The surface of the inferior wings is obscure brown, with a small yellow spot placed at the anal angle, and surmounting a yellow crescent. Their under side is reddish, tinged with green at the base; the middle traversed obliquely by a white angular band, which bears at its commencement on its inner side a black ocellus, having a pupil of bright white, and on its outer side four or five similar ocelli, the two anterior of which, and the anal one, when present, are smaller than the others. There is, besides, a curved silvery line along the posterior border.

"The caterpillar is green, with dark dorsal lines and yellow lateral rays. It lives on the Melica ciliata." *

The only British example that has occurred was found in the same place as H. Hero.

- Godart, Pap. de France. i. 174. 
The three following genera compose the family Lycanida of Dr Leach, and the Polyommatide of Swainson. Most of them are insects below the middle size, but all are distinguished by delicate markings, and many by great brilliancy of colour. The caterpillars are oval and depressed, and termed onisciform, from their resemblance to the small Myriapodae of the genus Oniscus. The genus TyecLA has antennæ gradually thickening to the apex, palpi with the terminal joint short, slender, and oval, eyes pubescent, and the claws undivicled and very minute. The upper wings are triangular and entire, but the secondary pair produce one or two caudal appendages near the anal arigle. All the species are brown above, and usually have the under side adorned with narrow undulating lines of pale yellow or white. The larvæ are never found on herbaceous plants, but confine themselves to trees and shrubs. 
PLATE 27.
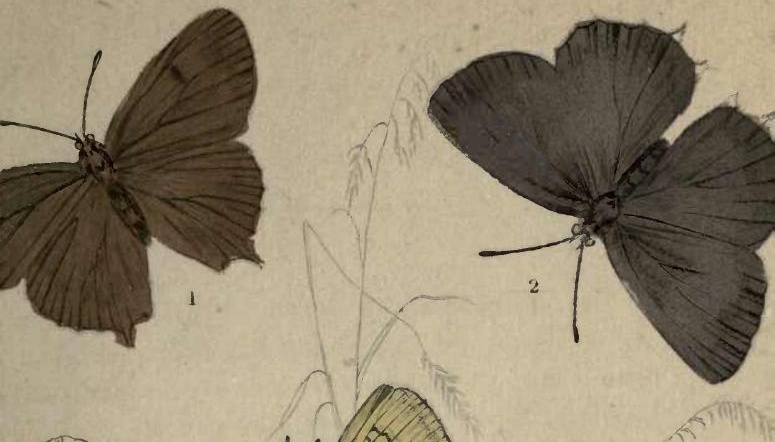

त
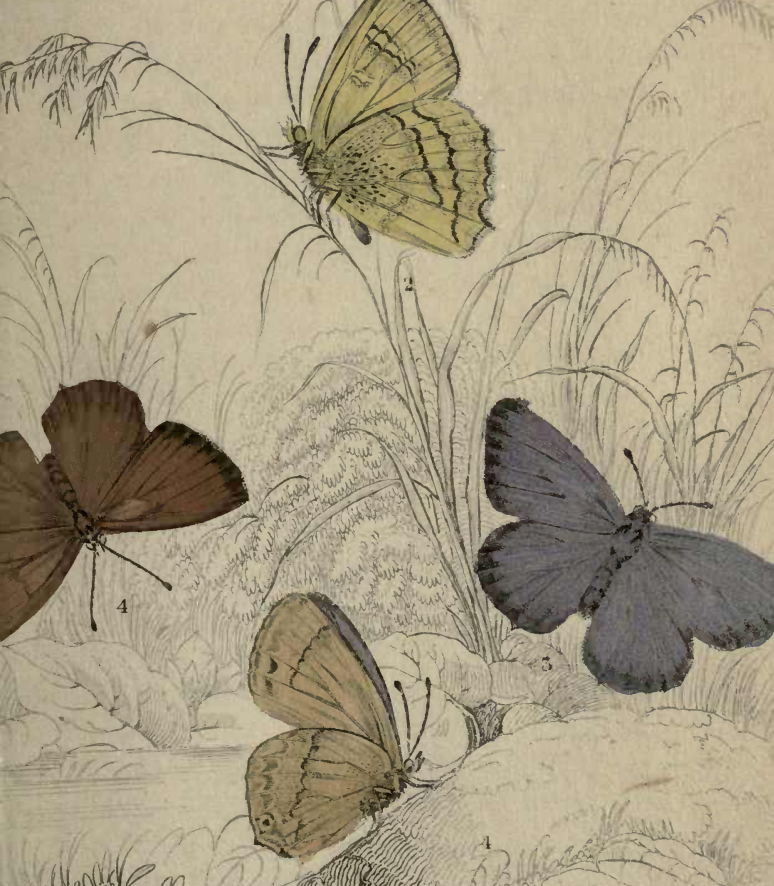

$=$ and and

In)

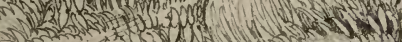





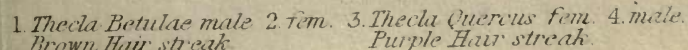
Brown Haw streak 









\section{BROWN HAIR-STREAK.}

Thecla Betula.

PLATE XXVII. FIGS. $1 \& 2$.

\section{Pap. Betulæ, Linn.-Lewin, pl. 42.-Donovan, viii. pl 250. + -Brown Hair-Streak, Harris.}

THIs is the largest British species of the present group, the expansion of the wings sometimes reaching eighteen lines. The colour of the upper side is dark brown, with a silky gloss, the fringe whitish; towards the middle of the anterior wings there is a blackish ill-defined mark, usually with a faint yellow cloud beyond it in the male, and a large kidney-shaped orange patch in the female. The secondary wings in both sexes are covered with fine silky hairs internally, and the two projecting lobes at the anal angle are marked with reddish-yellow. The under side is entirely tawny yellow, inclining to red at the hinder extremity, particularly of the posterier wings, with two narrow transverse undulating white lines, edged with black, the anterior one abbreviated, and forming only a dusky streak on the upper wings, edged, with white. The antennæ are ringed with white and the apex of the club is rust-red. 
The caterpillar is green, with yellow streaks along the back, and transverse rays of the same colour on the sides. It feeds on the common birch, blackthorn, plum, \&c. The fly appears about the beginning of August, but it is not often met with in this country, although abundant in most other parts of Europe. The following English localities may be mentioned, a few of which have afforded it in some plenty. Coombe-wood, woods near Ipswich, Reydon wood, Aridover, Dartmoor, Devonshire.

\section{PURPLE HAIR-STREAK.}

Thecla Quercus.

PLATE XXVII. Figs. 3 \& 4.

Pap. Quercus, Linn.-Lewin, pl. 43.-Donovan, xiii. pl. 460. -The Purple Hair-Streak, Hurris.-Thecla Quercus, Steph., Jermyn, \&c.

Ratuer a smaller species than the preceding, the extent of the wings being generally from thirteen to fifteen lines. The colour of the upper side is dark brown, the entire surface, in one of the sexes, faintly glossed with purple, and in the other there is a large oblong patch of deep glossy blue at the base of the upper wings, divided posteriorly into two branches, the hinder one being prolonged towards the anal angle. On the under side the wings are pubescent, of an ash-grey colour with a silky lustre, and tra- 
versed by a continuous undulating white streak, edged with brown anteriorly; beyond this there is a double series of faint whitish crescents, with a few dusky dots on the primary wings, and the secondary pair are ornamented with two fulvous spots, one on the anal angle, and the other forming an ocellus with a yellow iris and a black pupil.

The caterpillar, which invariably feeds on the oak, is of a greyish-brown colour, with a dark brown bead; the incisures and a row of dots along the back yellow.

The most common species of Thecla in this island, especially in the southern districts of England, where it may be found abundantly in every oak wood. It extends northwards in considerable plenty as far as Newcastle, in the neighbourhood of which, Mr Wailes informs us that it is far from uncommon. Beyond that locality, however, it seems to become scarce, and in Scotland it may be regarded as a rare species. The only Scotch examples that we have seen were from Roxburghshire, and the oak woods in the vicinity of Inverary in Argyllshire. 


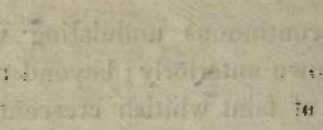

BLACK HAIR STREAR.

Thecla Pruni.

PLATE XXVIII. Frg. 1.

Pap. Pruni, Linn.-Ochsenheimer, Pap. Eur., tom. i.-Pa lyommatus Pruni, Godart, Lepid. de France.-Thecla Pruni, Curtis, Brit. Ent. vi. pl. 264.

EXPANSION of the wings somewhat more than an inch, the surface brownish-black, the upper wings with a small oblong spot near the middle anteriorly, and the hinder pair with a series of three or four crescent-shaped red marks near the posterior border. The under side is yellowish-brown; the primary wings with a transverse silvery line towards the hinder margin, beyond which, and parallel with it, there is a series of reddish spots, each of them bounded by a small black streak; the secondary wings have an irregular silvery line nearly across the middle, behind this a row of black spots, edged with white anteriorly, and a marginal series of black crescents.

The caterpillar is green, with longitudinal whitish rays, and numerous short transverse lines. The head, as in all the larvæ of this group, is small, and 
'of a yellow colour, with two black points in the form of eyes. (Plate III. Fig. 8.)

This species has been very often confounded with the following, which is of much more frequent occurrence in this country, and has been generally regarded as the true T. Pruni. Authentic indigenous examples of the latter were, we believe, first fizured and described by $\mathrm{Mr}$ Curtis, who states that t..e insect was found by Mr Seaman, in Yorkshire, in such abundance, that it is now to be seen in almost every cabinet. It is well known on the Continent, in some parts of which it is rather common.

WHITE LETTER HAIR STREAK.

Thecla W-album.

PLATE XXVIII. Fig. 2.

Pap. Pruni, Lewin. pl. 44.-Donovan, xiii. pl. 437.-Thecla Pruni, Jermyn,-Stephen's Illus. Haus. i. 77.-Dark or Black Hair Streak, Harris.-Polyommate W-blanc, Go. dart, Hist. des Pap de France.-Pap. W-album, Hubner.

Upper side dark brown, with a silky gloss, the upper wings of the male having a greyish spot near the middle, towards the anterior border. The under side is light brown, with a narrow transverse slightly interrupted white line, placed towards the linder margin in the primary wings, but near the 
middle in the secondary pair, and forming two acute angles posteriorly, in such a manner as to resemble the letter $\mathrm{W}$; behind this there is an irregular band of orange-red, widest towards the anal angle, and bounded on the inner side by a black line, which is sometimes edged internally with white; the margin itself, as well as the projecting tailed point, is black, sometimes tipped with white.

The caterpillar is green, with three spots of deep red on each of the posterior segments of the belly, and a double series of small dots along the back. When about to undergo its metamorphoses it becomes brown. According to some authors it feeds on the elm, while others mention the black thorn as its appropriate food.

This insect, as already mentioned, has been described by most British Entomologists as the $P$. Pruni of Linnæus, who does not appear to have been acquainted with it. Of late years it has occurred in great plenty in some districts, but in general it may be accounted scarce, particularly in the northern parts of the kingdom. "The boundless profusion," says Mr Stephens, "with which the hedges, for miles, in the vicinity of Ripley, were enlivened by the myriads that hovered over every flower and bramble blossom, last July (1828), exceeded any thing of the kind I ever witnessed. Some notion of their numbers may be formed, when I mention that I captured, without moving from the spot, nearly 200 specimens in less than half an hour, as 
they successively approached the bramble bush, where I had taken up my position. How to account for their prodigious numbers I am perfectly unable, as the same fields and hedges had been carefully explored by me at the same and different periods of the year for several preceding seasons, without the occurrence of a single specimen in either of its stages; and it is worthy of remark, that the hedges to the north and north-west of the village, were perfect$y$ free, although the brambles, \&c. were in plenty."

\section{GREEN HAIR-STREAK.}

\section{Thecla Rubi.}

PLATE XXVII. Fig. 3.

Pap. Rubi, Linn.-Lewin, pl. 44.-Donovan, xiii. pl. 443. -The Green Butterfly, Wilkes, pl. 118.-The Green Fly, or Bramble Fly, Harris.

Expansion of the wings about an inch, the surface of a uniform brown tint in both sexes, with the nervures somewhat darker, the female sometimes having a faint whitish oval dot near the middle of the upper wings, not far from the anterior border. The under side is " fine green, with a transverse row of white dots, often more or less obliterated, behind the middle of the secondary wings."

- Stephen's Illus., Haust. i. 77. 
The caterpillar is pubescent, light green or greenish-yellow, with a row of triangular yellow spots on each side, and a white line just above the feet. It feeds on brambles, broom, and many other plants. The fly appears in the end of May, and beginning of June; a second brood takes flight in August. It is not a very common species, but its ascertained localities indicate that it is pretty generally distributed throughout England and the southern division of Scotland. It occurs in Darenth Wood, Bromley Thickets in Essex, in Devonshire, \&c. We have seen many specimens from the neighbourhood of Raehills, and other parts of Dumfriesshire, and have observed the butterfly occasionally in some of the central districts of Roxburghshire, "Keswick, and some of the Yorkshire Wolds," G. Wailes, Esq. 


\section{0}

\section{Genus LYCAENA.}

THe species of this beautiful group are readily distinguished by the following characters. Antennæe with a slender stalk, the club rather thick, abrupt, and ovate, sometimes a little compressed at the apex; palpi longer than the head, the two lower joints scaly, the apical one, which is slender, pointed, and about balf the length of the second, appearing naked ; legs all formed for walking, and alike in both sexes; eyes naked. The secondary wings are nearly straight on the abdominal edge, and somewhat divergent, the anal angle slightly toothed, but not projecting like a tail as in the Thecla. All the species are remarkable for the brilliant coppery hue of their wings, whence they are known in this country by the name of Copper Butterflies. Most of them frequent marshy places, and the caterpillars feed on herbaceous plants. 


\section{LARGE COPPER.}

Lycena dispar.

PLATE XXIX. Figs. 1 \& 2.

Curtis, Brit. Ent. i. pl. 12.-Pap. dispar, Haw.-Pap. Hippothoë, Donovan, vii. pl. 217. -Lewin, pl. 40.-Lycæna Hippothoë, Jermyn -I. dispar, Swainson's Zoot. Illus. pl. 132.

THE male of this fine insect is bright shining copper colour above, with a black margin round all the wings, which is crenated in the hinder pair; the base of the primary, and the abdominal margin of the secondary wings is likewise blackish, and on the disk of the former are two small black spots, and near the middle of the latter a narrow curved black streak. The female has the upper wings broadly margined behind with black, two or three spots of the same colour arranged longitudinally on the disk, and a transverse row of six or seven black spots a little beyond the middle; the hinder wings are almost entirely black, except the nervures, and a broad band near the apex, which are coppery red. Beneath, both sexes are similar; the upper wings coppery, but with less lustre than the surface, having three black spots placed longitudinally, and a transverse row beyond the middle, all of them surrounded with a yel low ring; near the posterior margin there is another 

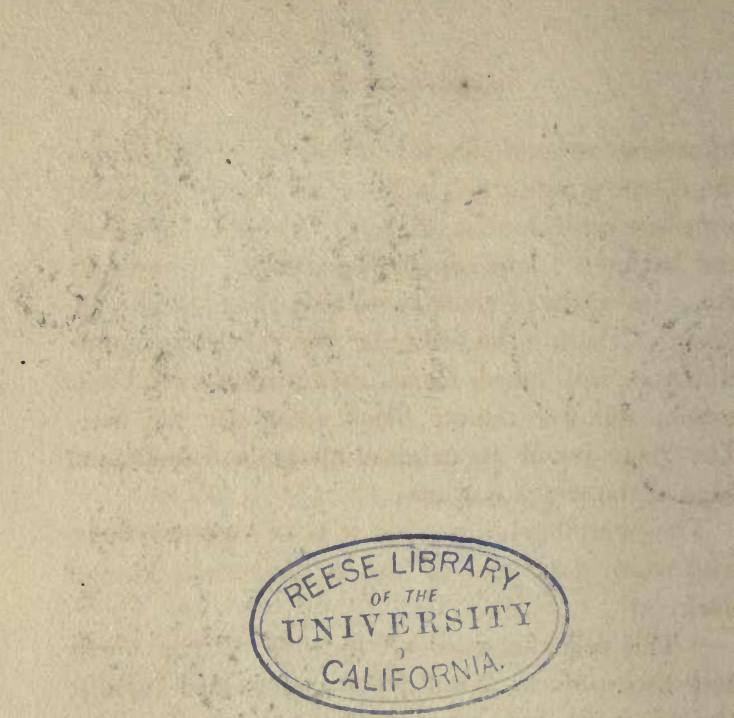
transverse series of simple black spots, beyond which the colour is ash-grey, inclining to blue; the under wings are ash-coloured, slightly tinged with light blue, and having a bright coppery band at the hinder margin, with a row of biack spots on each side of it ; before this there is an irregular row of black spots, cinctured with bluish-white, then a transverse black streak, and five remote black spots near the base. The fringe round the extermal margin and abdominal edge of the wings is white.

The caterpillar is described to be of a green colour, with white dots, and is said to feed on a kind of dock.

" This splendid species," says Mr Curtis, "was first discovered in Wales by the celebrated botanist Hudson. It has subsequently been captured in considerable abundance by Messrs Standish, who went to Wittlesea Meer, Huntingdonshire, in expectation of finding it. They inform me that the end of July is undoubtedly the right season for this insect, although they met with it the beginning of August, flying among reeds, about the centre of the Meer near Yaxley; that it is very active, and in windy weather conceals itself amongst the highest reeds. Upon these the caterpillar probably feeds, as they found the butterfly upon that plant just emergert from the chrysalis, drying its wings.' * Donovan states that the specimens from which his figures were drawn, were obtained from Scotland.

- British Entom vol.j. fol, 12. 


\section{SCARCE COPPER.}

\section{Lycana Virgaurea.}

\section{PLATE XXIX. Fig. 3 .}

Pap. Virgaureæ, Linn.-Donovan. v. 173, ơ.-Levin, pl. 41, fig. 1 and 2, o.-Steph. Illus. Haust. i. pl. 9, fig. 1 and 3 , đ. fig. 2 , + .

This species is rather less than the preceding, the male brilliant copper cotbur above, inclining to yellow, the wings margined externally with black, and the hinder pair having a few black spots near the posterior edge. On the under side, the primary wings are pale yellow, with three simple black spots before the middle, placed longitudinally ; behind this, there is a very irregular transverse row of black dots, and the hinder margin is clouded with dusky; the secondary wings are dusky towards the base, with about twelve or fourteen small black spots, five of them remote from each other placed before the middle, the rest forming an irregular cross band, behind which there is a series of white marks. The wings of the female are thickly spotted and clouded with black above.

The caterpillar is pubescent, and of a dull green, with a yellow dorsal line, and pale green streaks on 
the sides. It lives on the golden rod (Solidago vir. gaurea), and some other similar plants. The insect is very rare in this country, and does not appear to have been found for many years. Donovan says that a epecimen was once taken in Cambridge; the Isle of Ely, and Huntingdonshire, are likewise said to have afforded it; and Lewin states that he once caught two individuals in marshes, but without mentioning the precise locality. 


\section{PURPLE-EDGED COPPFE.}

Lycana Chryseis.

PLATE XXX. Fig. 1.

Hesperia Chryseis, Fabr._Pap. Chryseis; Purple-edged Copper, Haworth.-Sowerby, B. M. 1st. pl. 13.-Lverna Chryseis, Jermyn, Steph.

FulaID copper colour above, the base and outcr margin of all the wings brown, glossed with purple, and the centre of each wing marked transversely with a short, slender, black streak. The disk of the anterior wings beneath is orange, the anterior margin ashgrey ; and over the surface there are numerous ocellated spots, with a black pupil and white iris, three of them towards the base placed longitudinally, and the rest forming two irregular bands, of which the marginal one is somewhat obsolete: the posterior wings on the under side are glossed with blue at the base, and bear numerous scattered ocellated dots, forming irregular transverse rows towards the apex ; the latter ornamented with an orange band. The fringe is brown at the base, and white externally.

This is also a very rare insect in Britain. The only localities which we have heard of, are those 
PLATE 30.
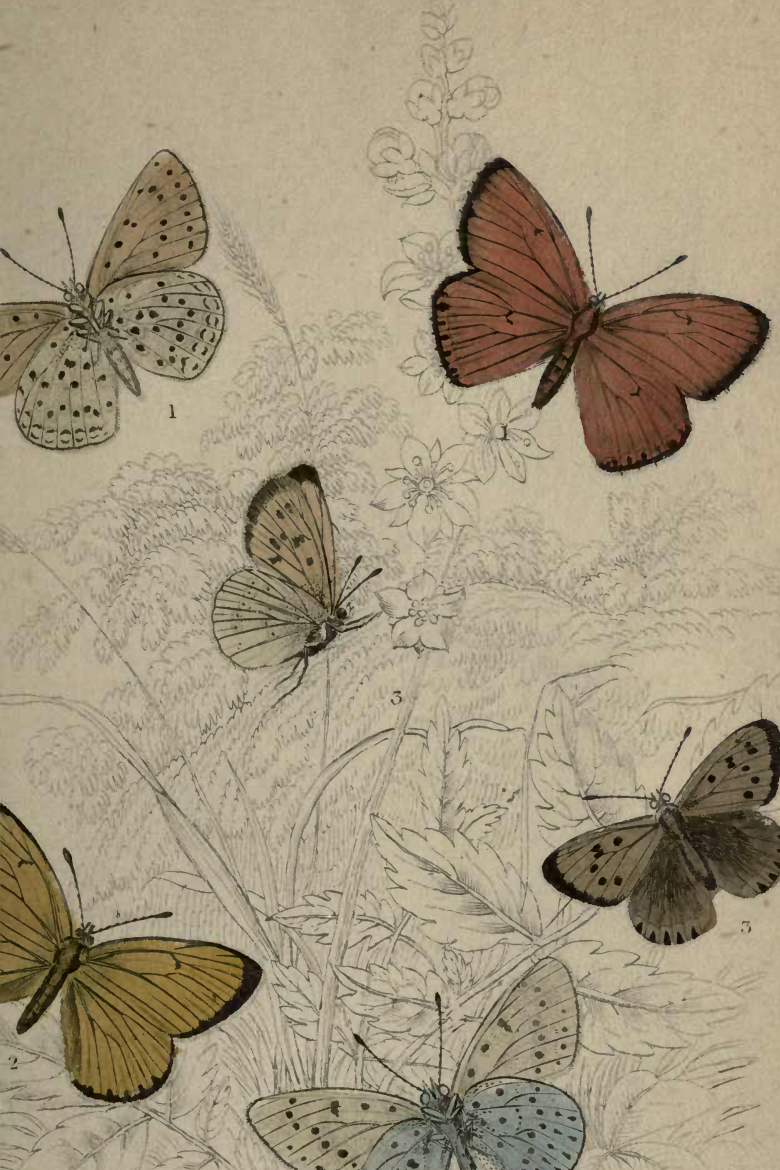


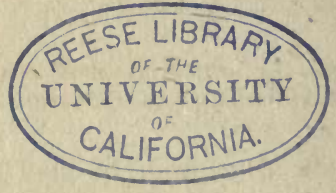

당 
cited by Miss Jermyn, viz. Epping Forest, Essex, and Ashdownham in Sussex.

\section{DARK UNDER-WING COPPER}

\section{Lyccena Hippothoë.}

PLATE XXX. Frg. 2.

Pap. Hippothoë, Linn.-Lycena Hippothoë, Stephens.Dark Under-winged Copper, Haworth.

Expansion of the wings from 15 to 17 lines, the colour of the surface bright fulvous, with a narrow external black border, which is entire in the primary wings, but crenated internally in the secondary: besides this, there is a minute transverse black mark in the middle of each wing. The superior wing are yellowish beneath, inclining to ash colour, with numerous black spots cinctured with white; the inferior pair ash-coloured, with many ocellated dots, and a fulvous band posteriorly, spotted on each side with black. In the markings on the upper side, the female resembles the same sex of the preceding species; but the hinder wings are entirely black, except a posterior band of yellow, crenated on its outer side.

Only one or two specimens of this insect have been fourd in Britain, and they seem to have been 
procured from the county of Kent. In France it is not very scarce, and frequents meadows and marshy places.

\section{COMMON COPPER.}

\section{Lycana Phlaas.}

PLATE XXX. Fig. 3.

Pap. Phlæas, Linn.-Lewin, pl. 41.-Donovan, xiii. pl. 466.

-The Copper Butterfly, Harris._Lycæna Phlæas, Jermyn, Stephens.

UPPER wings fulgid copper colour, the posterior margin black, and the disk of each wing bearing from 8 to 10 black spots, two of them arranged longitudinally towards the base, the rest transversely in a zig-zag band, some of them confluent. The hinder wings are brownish-black, with a coppery band posteriorly, dotted with hlack on its outer edge. The under side of the primary wings is spotted in a similar manner to the upper side, but the colour is paler, and the hinder margin greyish, with three black crescents internally: the secondary wings drab coloured beneath, with many indistinctly marked dots, and a posterior tawny band.

This is the smallest species of the genus, the expansion of the wings seldom exceeding 12 or 14 lines, and differs from the others in both sexes be- 
ing nearly alike. It is liable to considerable variation in its markings, and specimens have been found in which those parts of the surface usually copper colour were nearly pure white. It is rather common in all parts of Britain, and seems to breed several times in the year. It likewise occurs in Asia and in North America. The caterpillar is said to be clear green, with a yellow dorsal stripe, and to feed on the Sorrel. 


\section{Genus POI,YOMMATUS.}

Distinguished from the two preceling genera by having the wings entire, without any tail-like appendages, and without any distinct teeth near the anal angle. The antennæ are rather short, and terminate in an abrupt compressed club, ending in a narrow point rising from one side. The palpi project a little beyond the head, are nearly parallel, and have the basal and terminal joints almost of equal length, the latter acute, and somewhat naked, or ('overed with scales only, the others being clothed with scales and hairs. The tarsi terminate in simple claws. This genus includes all the small blue butterflies, which are seen in such numbers during the summer months in pastures and grassy glades. They are adorned on the surface with the most delicate and varied shades of blue and azure, and beneath with a multitude of eye-like spots. It is this latter circumstance that has suggested the generic name, it being formed from the Greek words moxis,

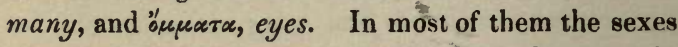
are dissimilar in colour; but in $P$. aslus, agestis, and Artaxerxes, the sexual differences are not so strongly marked. The larvæ of several of the species are not known, but most of those with which we are acquainted feed on grasses and herbaceous plants, on which also they undergo their metamorphoses. 



1. Polyommatis Argiolus, Ifule ? Female Axure bluce.

5. Alsus. Betford blue.

4. Acis. Marapine bline. 

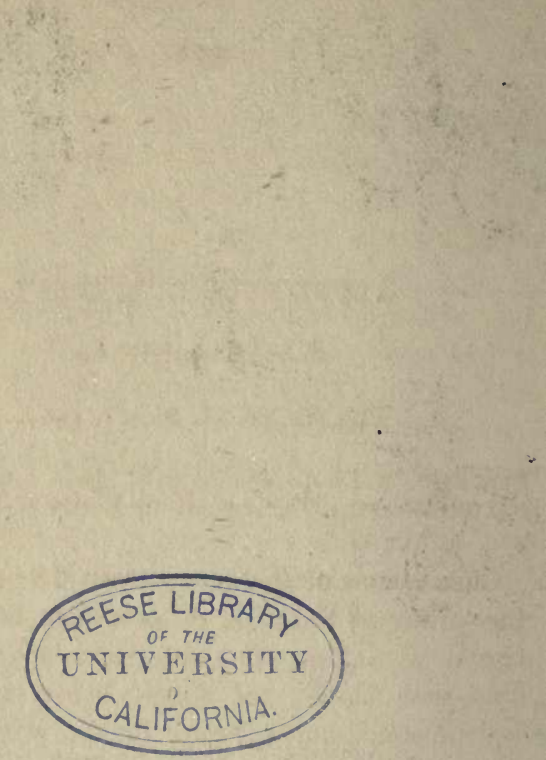

호 


\section{9}

\section{AZURE BLUE BUTTERFLY.}

Polyommatus Argiolus.

\section{PLATE XXXI. FIos. 1. AND 2.}

Pap. Argiolus, Linn-Lewin, pl. 36. figs. 4, 5, 6.-Donovan, xiv. pl. 481.-The Azure Blue Butterfly, Harris.

Expansion of the wings about 13 or 16 lines; the surface of the male delicate light blue, slightly tinged with lilac, the wings narrowly edged behind with black; the female lighter blue above, with a broad dusky border in the primary wings, and a transiverse series of spots of the same colour near the binder elge of the secondary pair. Bcneath, the colour is grey, faintly tinged with blue, the upper wings with a slender curved spot or streak in the middle, and a posterior band of five or six narrow black streaks, that next the anterior margin placed by itself : the hinder wings marked in a similar manner, with the addition of several scattered spots towards the base. The fringe on the superior wings is white, interrupted with black when seen from above, but on the hinder pair, and on the under side of all, it is nearly white. The number of spots varies greatly in different individuals; at times 
they are very distinctly marked, and frequently many of them are obsolete, or entirely obliterated.

The caterpillar is pubescent, of a greenish-yellow, deepest on the back; the head and legs black. It is found on the Buckthorn and Holly.

The buttertly, which appears twice in the year, viz. in May, and near the end of July or in August, is plentiful in many parts of England. It is of frequent occurrence in Kent, Somersetshire, Hampshire, and Devonshire; also near London, and in Norfolk and Suffolk. It is rather scarce in the north, although it is found not unfrequently near Newcastle, in places where hollies abound; and alse in Castle Fden Dean.

\section{BEDFORD BLUE BUT'IERFLY.}

Polyommatus Alsus.

PLATE XXXI. Fig. 3.

Pap. Alsus, Donovan, ix. pl. 322. fig. 1.-Lewin, pl. 39. f.3, 4. -Bedford Blue, Leach.-Small Blue Butterfy, Haworth.

THIS is the smallest of British Butterflies, the wings sometimes not exceeding 10 lines between the tips, and seldom surpassing an inch. The surface is brown, with a silky gloss, one of the sexes slightly tinged with blue. especially at the base of 
the wings. The under side is ash coloured, with a discoidal black crescent, edged with white, on each wing, and a transverse series of ocellated dots towards the hinder margin; on the hinder wings this series is very irregular, and there are several scattered spots towards the base. Fringe of the wings white.

This delicate little butterfly, the smallest of the European Polyommati, seems to occur, but not in great abundance, in most parts of the kingdom. Numerous localities, scattered over the southern parts of England, have been cited for it. Mr Wailes informs us that it is common on the magnesian limestone district near Newcastle: it is also found in woods near Durham; and we have seen specimens from most of the southern counties of Scotland.

\section{MAZARINE BLUE BUTTERFLY.}

\section{Polyommatus Acis.}

\section{PLATE XXXI. Fig. 4.}

Polyommatus Acis, Stephens.-Pap. Cymon, Lewin, pl. 38. f. 6. \& 7.-Polyom. Cymon, Jermyn.-Lycæna Cymon, Leach-Pap. Argiolus, Hübner.

Expands about 13 or 14 lines, the male deep blue above, glossed with violet, having a narrow black border to all the wings, and a white fringe. The 
female is dark brown above, with the base of the wings faintly tinged with blue, and the fringe greyish. The under side is ash-grey, inclining to blue at the base of the wings, the anterior pair of the lat. ter with an oblong spot, cinctured with white, near the middle, and a band of ocelli behind it, usually most numerous in the male. On the disk of the posterior wings there is also a streak of black, two or three spots anteriorly towards the base, and a very irregular band of ocelli, having a black pupil and white iris, behind the middle.

Rather a scarce species, and usually found to frequent chalky districts. It has occurred in Norfolk, Dorset, and Yorkshire; also in Surrey, Cambridge, \&c. 

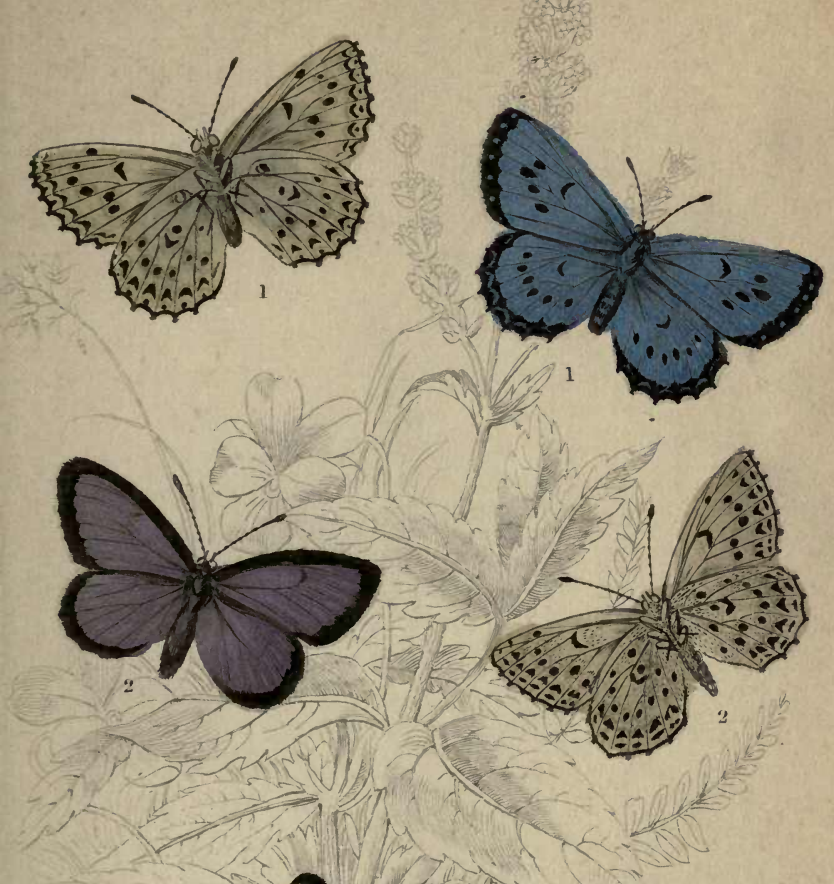

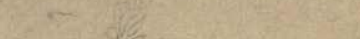


REESE LIBRAPY
OF THE
UNIVEITITY
CALIFORNIA.

(5)

A






\section{3}

KARGE BLUE BUTTERELY.

Polyommatus Arion.

PLATE XXXII. Fig.

Linn.-Lewin, pl. 37.-Don.

Considerably larger than any of the preceding, sometimes measuring an inch and a half across the wings. The upper side is pale violet-blue, with a broad dusky border round the hinder margin of ali the wings, the male having a group of black spots on the disk of the upper pair, of which the interior one is transverse and somewhat curved, and the female has a similar group on the disk of all the wings. The under side is ash-coloured, inclining to brown; the anterior wings with two ocelli towards the base, an irregular band of 6 or 7 others behind the middle, and a row of lunules, with a small white mark adjoining each: the posterior wings bluish at the base, where there are four scattered spots, the disk bearing a black lunule, behind which there is an interrupted band of eight large ocelli; the posterior margin ornamented with a row of triangular or crescent-shaped black spots; fringe white spotted with brown beneath. 
This beautiful insect, which is extremely rare in Britain, and not of frequent occurrence on the Continent, is said by Lewin to have been taken on Dover Cliffs, Marlborough Downs, and on the hills near Bath. Miss Jermyn mentions the commons at Broomham in Bedfordshire, and certain places in North Wales, as having afforded it. More recently it was found by $\mathrm{Mr}$ Dale in the neighbourhood of Bedford.

\section{ALCON BLUE BUTTERFLY.}

Polyommatus Alcon.

PLATE XXXII. Fig. 2.

Polyommatus Alcon, Latreille.-Hesperia Alcon, Fabr.Pap. Alcon, Hubner.

SURFACE of the male violet-blue, with a rather wide brown border to all the wings, and a dark crescent on the disk of the upper pair; of the female dusky brown, tinged with blue towards the body. Under side greyish in both sexes, with a central crescentshaped spot, bordered with white, on each wing; behind this there is a curred row of rather large rounded black spots, and two exterior rows of triangular marks, all of them encircled with white; the basal half of the hinder wings is tinged with blue, and bears a few scattered spots in addition to those cor- 
responding to the markings of the superior wings: fringe white, spotted with brown.

As this insect appears to have been found only once in this country, and is not figured by any British author, we have been obliged in this instance to deviate from our usual practice, and introduce a figure taken from a foreign specimen. It does not entirely correspond to Mr Stephens's description of the supposed indigenous example discovered by $\mathrm{Mr}$ Jones in Buckinghamshire; and should the latter be found, as has been conjectured, to be only a variety of $P$. Arion, we must exclude the present specips from our native catalogues.

\section{CHALK-HILL BLUE BUTTERFLY.}

\section{Polyommatus Corydon.}

PLATE XXXII. Fig. 3.

Pap. Corydon, Donovan, vii. pl. 131. f. 1. J.-Stephens Illus. i. 88.-Lewin, pl. 36. -The Chalk-Hill Blue Butterfly, Harris.

ONE of the larger species, generally measuring 17 or 18 lines across the wings. The surface of the male is a very light silvery blue, with a fine silky lustre, the hinder margin of all the wings having a blackish band, surmounted in the hinder pair by a series of dusky, somewhat ocellated spots : the sur- 
face of the female brown, each wing with a p?, central spot, having a black pupil in the primary wings. The under side of both sexes is simila but the secondary wings in the female are more deeply coloured, and the spots larger and more distinctly marked : the anterior wings whitish, marked nearly as in $\boldsymbol{P}$. Arion: the hinder ones of a similar colour, greenish at the base, the ocellated spots arranged in two curved bands, that next the base consisting of four, the second, which is placed rather behind the middle, of eight; in the centre, between these bands, there is an angular white spot; and on the hinder margin a series of black spots, with a white iris surmounted by a streak of orange, and a triangular black spot, with its apex directed inwards; an oblong white patch connects this series with the central band. Fringe white, spotted at regular intervals with brown; on the under side of the secondary wings entirely white.

Somewhat restricted in its distribution, but occurring in certain localities in great profusion. It chiefly frequents districts where chalk abounds, and from having been long found in plenty on a range of hillocks between Dartford and Darenth Wood, it has received the name of "Chalk-Hill Blue." It inhabits the vicinity of Dover, the Isle of Wight, " Little Blakenham, Moulton, and Eriswell in Suffolk;" stone-quarries near Peterborough, \&c. \&c. The caterpillar, of which we have never seen any description, has been stated to feed on Wild Thyme. 


\section{CALIFORNIA.}

츨 


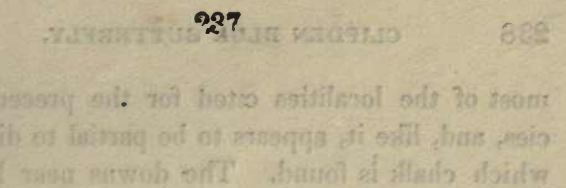

CLIFDEN BI UE BUTTERF'.

Polyommatus Adonis.

PLATE XXXIII. FIGS. 1. \& 2.

Hesperia Adonis Fab.-Pap. Adonis, Lewin, pl. 38. fig. 1-3. -Pap. Argus, '. Donovan, iv. pl. 143. f. 1.-Polyommatus Adonis, Steph. Jermyn._Clifden Blue, Harris.

Expansion of the wings 14 or 15 lines, the surface of the male of the purest and most beautiful azure, or silvery blue, changing with the light into lilac, the hinder margin of all the wings edged with a black line, beyond which there is a white fringe, distinctly spotted with brown both above and below. The female is brown above, slightly glossed with blue at the base, having a small discoidal black spot on the primary wings, and on the others a posterior fulvous streak, with slightly ocellated spots, sometimes continued across we margin of the upper wings. On the under side, the colour is brownishgrey, with the base of the wings greenish-blue, the markings disposed nearly as in $\boldsymbol{P}$. Corydon, but the discoidal white spot is small, forming only a transverse streak.

Of frequent occurrence in many parts of England, especially in the southern counties. It occurs in 
most of the localities cited for the preceding species, and, like it, appears to be partial to districts in which chalk is found. The downs near Brighton, Moulton and Dalham in Suffolk, Newoort, Coombe Wood, \&c. dirora it in consiaerabie numbers. 


\section{9}

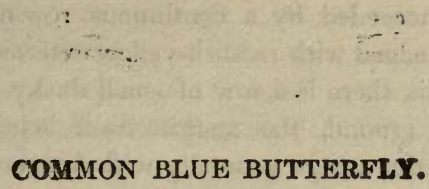

Polyommatus Alexis.

(See Vignette.)

Pap. Alexis, Hubner.-Pap. Icarus, Lewin, pl. 38.-Pap. Argus, Donovan, iv. pl. 143. of (two upper figs.)-Blue Butterfly, Harris.-Pap. Hyacinthus, Lewin, pl. 37. f. 4-6, var.-Polyom. Thestylis, Jermyn, var.

Aвоuт the size of the preceding, which it very much resembles, but is readily distinguished by the colour of the surface, which is bright lilac-blue in the male, and by the fringe of the wings being white and unspotted. The hinder border is narrowly margined with black; the anterior edge of the upper wings is white, and the hairs on the body and base of the wings incline to that colour. The female is generally brown above, powdered with blue towards the base of the wings (sometimes, however, the surface is entirely purplish-blue), and ornamented with a posterior fulvous band, somewhat ocellated on the hinder pair, each lunule having a central black spot. Beneath, brownish-ash colour, with the base inclining to green, the upper wings usually having two ocelli near the body, a slender central streak lying transversely, and a curved row of ocelli near the 
middle, succeeded by a continuous row of dusky crescents, edged with reddish-yellow externally; and beyond this there is a row of small dusky spots on a whitish ground, the margin itself being black. The posterior wings generally with four ocelli near the base, an angular white spot near the middle, frequently having a black streak in its centre, a curved band of 8 or 9 ocelli, succeeded by a series of markings similar to those on the superior wings, but the crescents and fulvous patches larger and more conspicuous; a white blotch near the middle unites the band of ocelli with the fulvous crescents.

This species is so variable in its markings, anis even in the form of the wings, that some entomologists are of opinion that more than one distinct species may be included under the name. It is a very abundant insect, and, unlike the rest of its associates, is distributed over the whole country. It frequents pasture-lands and grassy meadows, first appearing in England about the end of May, but not generally in Scotland till the middle or end of June. There is a second brood in August. The caterpillar is pubescent, and of a green colour. It appears to be polyphagous, but probably subsists chiefly on grasses. 


\section{SILVER-STUDDED BLUE BUTTERFLY.}

Polyommatus Argus.

PLATE XXXIII. FIG. 3.

Pap. Argus, Linin.-Lewin, pl. 39. fig. 5-7._Silver-studded Blue, Harris. - + Pap. Idas, Linn._Polyom. Argus, Jermya, Steph.

MaLe deep blue above, inclining to lilac, with a broad black band round the hinder margin of all the wings, the nervures likewise more or less of that colour; the costa and fringe white, the latter occasionally obscured with brown at the base. The under side is bluish-grey, the blue becoming more intense at the base, adorned with numerous ocellated spots; on the hinder margin of the posterior wings there is an interrupted orange-tawny band, containing six bright silvery-blue spots, crowned with a series of black crescents. The female is entirely brown above, with a tawny marginal band, which is obsolete on the interior wings.

The caterpillar is dull green, with the head and legs blackish, a ferruginous line along the back, and oblique ones of the same colour, bordered with white, on the sides. It feeds on broom, sainfoin and various kinds of trefoil. The butterfly is rather 
242 SILVER-STUDDEN BLUE BUTTERFLY

common in many parts of the south of England, and is found as far north as York, where it is not rare. It must be very scarce, however, northwards of that city, and it probably does not occur at all in Scotland. 
W CALIFORN

\section{한}

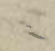




\section{3}

\section{BROWN ARGUS BUTTERFLY.}

Polyommatus Agestis.

PLATE XXXIV. Fig. 1 .

Pap. Agestis, Hubner.-Pap. Idas, Leuin, pl. 39. f. 1-2.Donovan, x. pl. 322. f. 2.-Polyom. Idas, Jermyn.-Polyom. agestis, Stephens.

Expands about an inch, the colour in both sexes dark-brown, with a fine silky gloss, all the wings having a posterior band of deep red spots, and the primary pair a small black spot in the centre: the fringe varied with white and brown. The under side is greyish-brown, with numerous ocellated spots, and a rufous band corresponding to that on the surface; the hinder wings with a white blotch on the disk.

Readily distinguished from the females of any of the preceding species, by the wings being without any tinge of blue, either above or below, and from either of the following, by wanting the white spot on the disk of the interior pair. It occurs in some plenty in Sussex, Kent, Dorset, Somerset, and many other parts of England, appearing first in June, and again in August. 


\section{DURHAM ARGUS.}

\section{Polyommatus Salmacis.}

PI.ATE XXXIV. FIGS. 2. AND 3.

Polyommatus Salmacis, Stephens.

SiLky brown above, with a macular posterior band of orange-red on all the wings, somewhat obsolete in the male, and a white spot on the disk of the primary wings, which, however, is occasionally wanting in both sexes, but especially in the female. The fringe is white, slightly variegated with brown at the base. The colour of the under side is greyish-brown, the anterior wings with a discoidal white spot, beyond this a curved band of similar spots, with a minute dusky pupil, succeeded by a band of orange spots, bounded on both sides by a dusky crescent, surmounted with white, the outer margin defined by a dusky line: the hinder wings have a similar marginal band, several scattered white spots towards the base, a larger one near the centre, and a very in regular row behind the middle, with a broad white central patch connecting it with the yellow band. Most of these spots have a minute dusky pupil in the male, but greatly more conspicuous in the female. 
Found in some plenty at Castle Eden Dean, ncar Durham, and also on the magnesian limestone district near Newcastle, where it occurs in considerable numbers in July.

\section{ARTAXERXES BUTTERFLY.}

\section{Polyommatus Artaxerxes.}

\section{PLAT'E XXXIV. FIG. 4.}

Hesperia Artaxerxes, Fabr.-Pap. Artaxerxes, Lewin, pl. 38. f. 8, 9.-Donovan, xvi. pl. 541.-Polyom. Artaxerxes, Jermyn, Steph.

DARK brown above, glossy, each of the anterior wings with a discoidal white spot, and all of them with an orange-red band posteriorly, but very indistinct on the upper wings. On the under side, the markings of the wings do not differ materially from those of $\boldsymbol{P}$. Salmacis, excepting in this, that the spots are nearly all without a black pupil. In some specimens, a minute white spot is observable on the disk of the posterior wings on the upper side.

The history of this little butterfly is somewhat curious. The only locality known, for a long period, was Arthur's Seat, near Edinburgh, and it is only of late that it has been found elsewhere. Fabricius appears never to have seen a specimer, the description in his System being taken from a 
drawing by $\mathrm{Mr}$ Jones of Chelsea. It was long much valued by the English collectors, some of whom, we are informed by Donovan, were in the habit of placing a drawing of the insect in an obscure corner of their drawers, that their cabinet might obtain credit for possessing an object of such rarity! Others undertook a journey to Edinburgh, shiefly with the view of procuring specimens. It occurs in such plenty on Arthur's Seat, that all the English cabinets, and the principal foreign ones, are now abundantly supplied from that locality. It has iikewise been taken among the Pentland Hills, at Flisk in Fifeshire, near Queensferry, and in the vicinity of Jardine Hall, Dumfriesshire. It appears in July. The examination of an extensive series of specimens of the two preceding insects, will probably lead most people to the belief, that the marks which have caused them to be regarded as specifically different, are far from being stable or satisfactory. The appearance of the caterpillars, both of which are unknown, will afford the most likely means of determining the point.

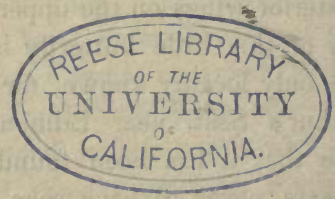






2.



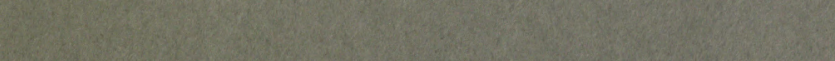
19.5.

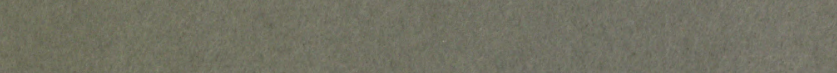

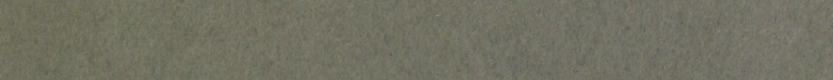
T.

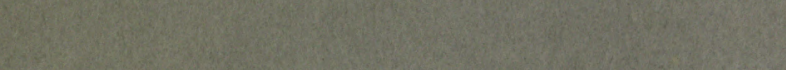
Q.7.


W. 13. W. (5) (1)

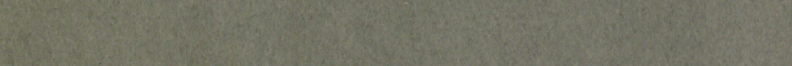

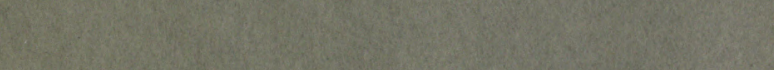


P. (19: (2) Q6. A

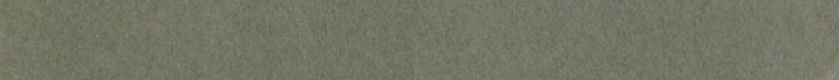

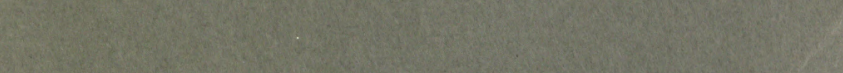

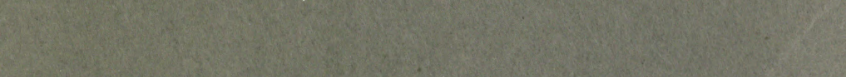
W.

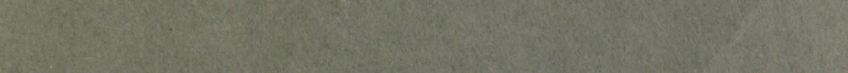

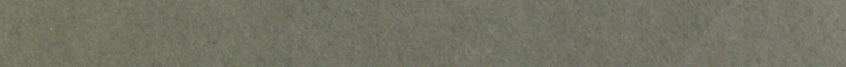

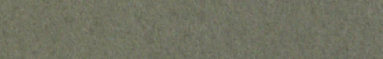

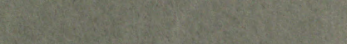


15.5. 19. and

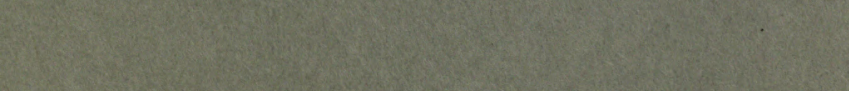



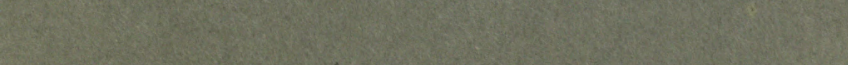
Q6. 


\section{DAY USE}






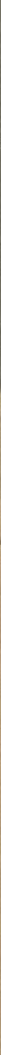


